Prepared in cooperation with the City of Wichita, Kansas, as part of the Equus Beds Groundwater Recharge Project

\title{
Water Quality of the Little Arkansas River and Equus Beds Aquifer Before and Concurrent with Large-Scale Artificial Recharge, South-Central Kansas, 1995-2012
}

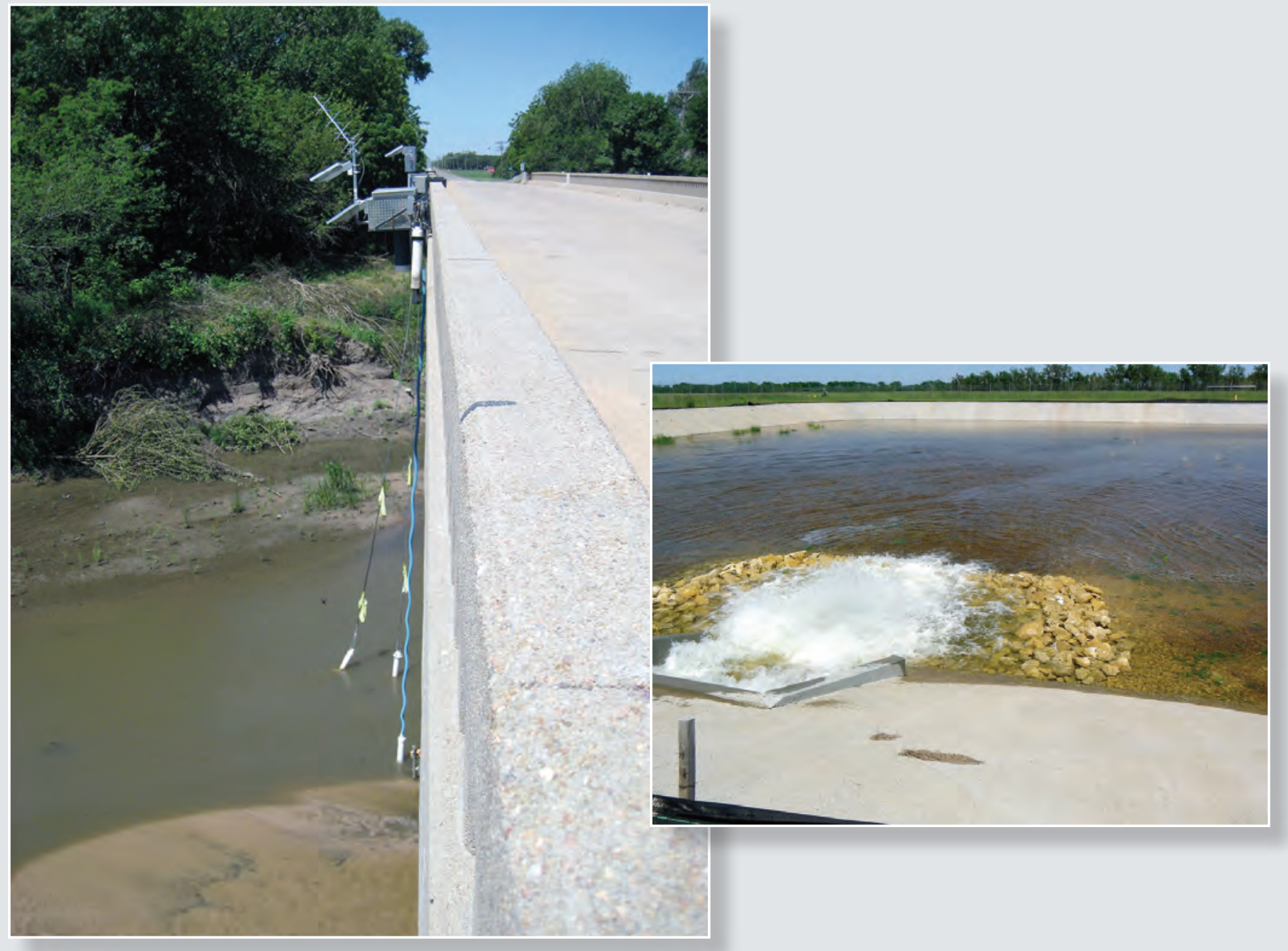

Scientific Investigations Report 2015-5023

Version 1.1, May 6, 2015 
Cover. Left photograph: The Little Arkansas River near Sedgwick, Kansas, May 2012, taken by Mandy Stone, U.S. Geological Survey, Lawrence, Kansas. Right photograph: A recharge basin during high operation in south-central Kansas, March 2015, taken by Trudy Bennett, U.S. Geological Survey, Wichita, Kansas. Back photograph: A recharge basin during low operation in south-central Kansas, August 2012, taken by Trudy Bennett, U.S. Geological Survey, Wichita, Kansas. 


\section{Water Quality of the Little Arkansas \\ River and Equus Beds Aquifer Before and Concurrent with Large-Scale Artificial Recharge, South-Central Kansas, 1995- 2012}

By Daniel J. Tappa, Jennifer L. Lanning-Rush, Brian J. Klager, Cristi V. Hansen, and Andrew C. Ziegler

Prepared in cooperation with the City of Wichita, Kansas, as part of the Equus Beds Groundwater Recharge Project

Scientific Investigations Report 2015-5023

Version 1.1, May 6, 2015 


\title{
U.S. Department of the Interior SALLY JEWELL, Secretary
}

\section{U.S. Geological Survey Suzette M. Kimball, Acting Director}

\author{
U.S. Geological Survey, Reston, Virginia: 2015 \\ First release: 2015 \\ Revised: May 6, 2015 (ver 1.1)
}

\begin{abstract}
For more information on the USGS - the Federal source for science about the Earth, its natural and living resources, natural hazards, and the environment—visit http://www.usgs.gov or call 1-888-ASK-USGS.

For an overview of USGS information products, including maps, imagery, and publications, visit http://www.usgs.gov/pubprod/.
\end{abstract}

Any use of trade, firm, or product names is for descriptive purposes only and does not imply endorsement by the U.S. Government.

Although this information product, for the most part, is in the public domain, it also may contain copyrighted materials as noted in the text. Permission to reproduce copyrighted items must be secured from the copyright owner.

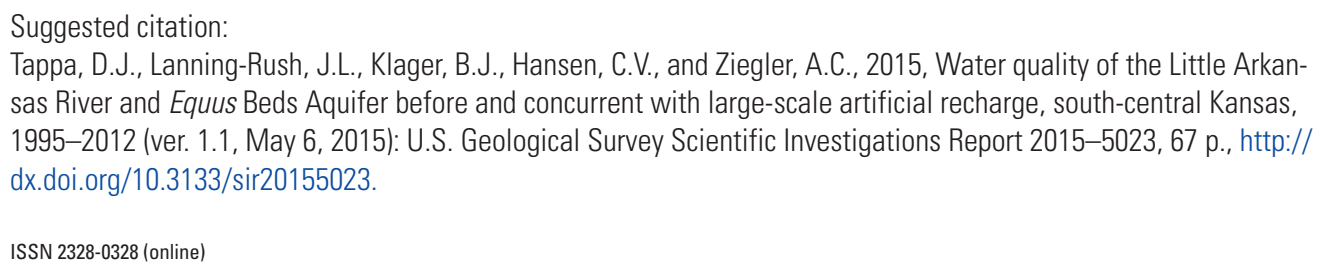

ISSN 2328-0328 (online) 


\section{Acknowledgments}

The authors acknowledge the invaluable assistance of several city of Wichita employees and Groundwater Management District 2 personnel, who contributed to this study. Well data were received from Equus Beds Groundwater Management District Number 2 (GMD2) managers Mike Dealy and Tim Boese. Gratitude is also expressed to Terryl Pajor, Vernon Strasser, and laboratory staff at the city of Wichita Municipal Water and Wastewater Laboratory for laboratory analyses.

Technical colleague reviews by Scott Prinos (U.S. Geological Survey [USGS]) and Mandy Stone (USGS) contributed to improved technical and editorial clarity of the report. Trudy Bennett, Carlen Collins, and Barb Dague of the USGS Kansas Water Science Center collected water samples, measured water levels, and maintained automated equipment at monitoring sites. Deneise Schneider (USGS) completed data entry, database maintenance, and quality assurance. 



\section{Contents}

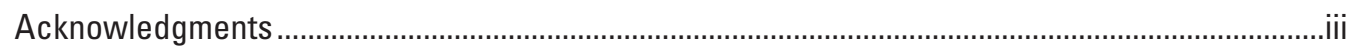

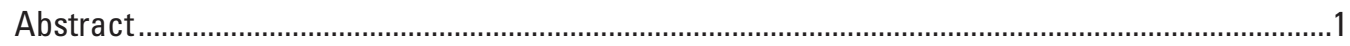

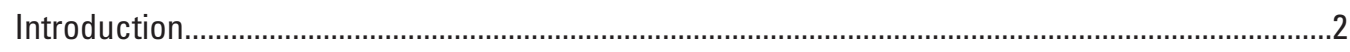

Equus Beds Aquifer Artificial Recharge ........................................................................ 2

Description of Study Area and Background ........................................................................

Purpose and Scope ..........................................................................................................

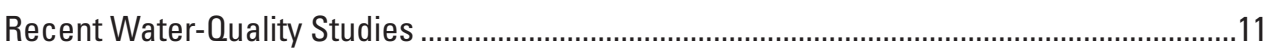

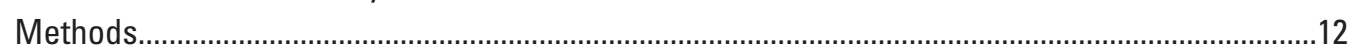

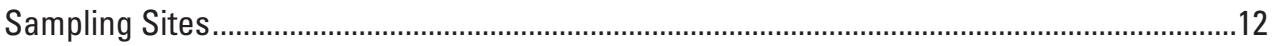

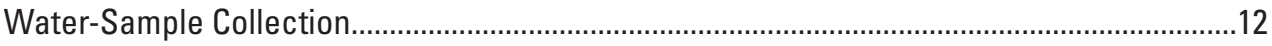

Discrete Surface and Groundwater-Quality Samples ...................................................12

Continuous Surface Water-Quality Monitoring ...................................................................15

Quality Assurance and Quality Control ..............................................................................

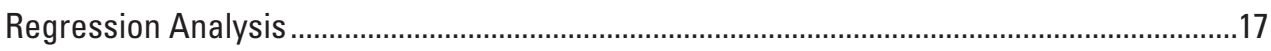

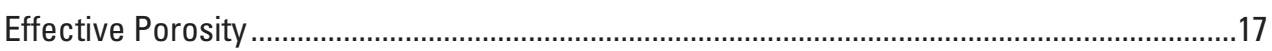

Water-Quality Constituents of Concern ................................................................................17

Water Quality of the Equus Beds Aquifer and Little Arkansas River, 1995-2012 ….......................17

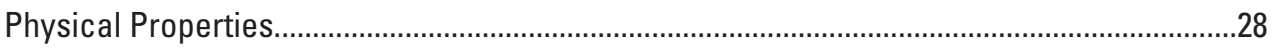

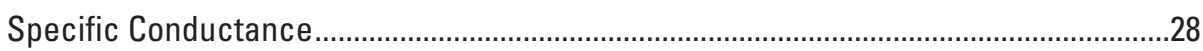

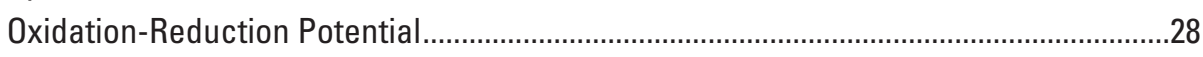

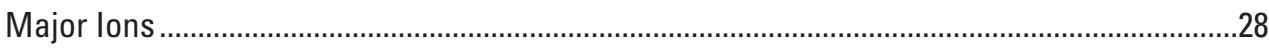

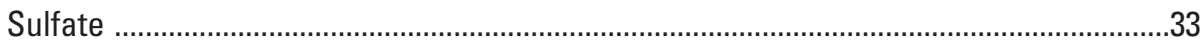

Chloride

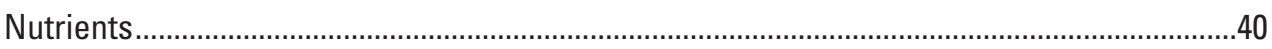

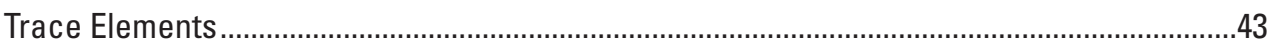

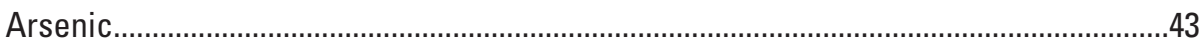

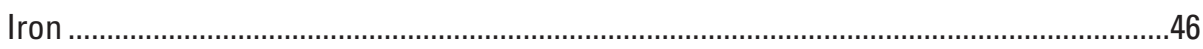

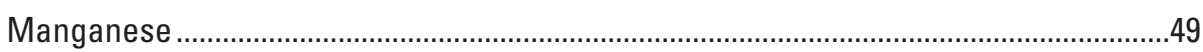

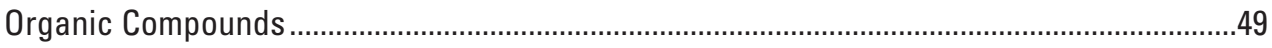

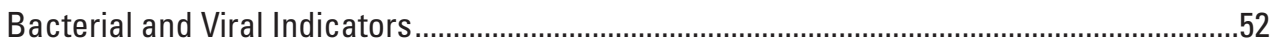

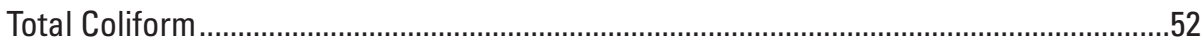

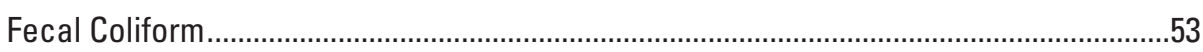

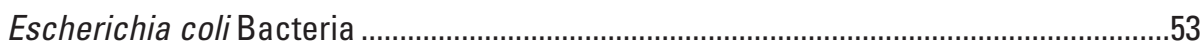

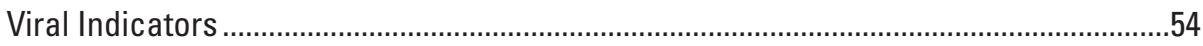

Timeline of Water Quality at and Near Phase I Recharge Sites .............................................55

Summary and Conclusions.......................................................................................................

References Cited

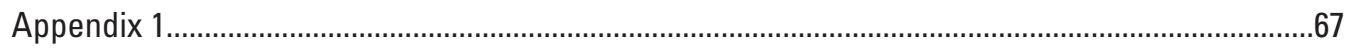




\section{Figures}

1. Map showing location of the study area near Wichita, south-central Kansas. ...............4

2. Map showing bedrock altitude in and near the study area, south-central Kansas..........6

3. Map showing static water-level altitudes in the shallow part of the Equus Beds aquifer, winter 2012, south-central Kansas.

4. Graphs showing average annual precipitation in and near the study area; and water use for the city of Wichita public supply and agricultural irrigation, 1938-2012, south-central Kansas.

5. Map showing water-level changes in the shallow part of the Equus Beds aquifer, 1993 to summer 2012, south-central Kansas.

6. Map showing water-level changes in the shallow part of the Equus Beds aquifer, predevelopment (1940) to summer 2012, south-central Kansas.

7. Map showing location of surface water and shallow groundwater monitoring sites; and surface water and deep groundwater monitoring sites in and near the study area, south-central Kansas.

8. Map showing estimated effective porosity in the study area, south-central Kansas ....18

9. Map showing average specific conductance in and near the study area, 2006-2012, south-central Kansas, in shallow wells and deep wells

10. Map showing average oxidation-reduction potential in and near the study area, 2006-2012, south-central Kansas, in shallow wells and deep wells.

11. Map showing average sulfate concentrations in the study area, 2006-2012, south-central Kansas, in shallow wells and deep wells

12. Graph showing duration curves of computed dissolved chloride concentrations, 1999-2012, Little Arkansas River near Halstead and near Sedgwick, Kansas.

13. Map showing average chloride concentrations in and near the study area 2006-2012, south-central Kansas, for shallow wells and deep wells.

14. Map showing changes in chloride concentration near Burrton, Kansas during 1982-2012

15. Graphs showing chloride concentrations in IW-05 and Phase I recharge at RRW-03 in the Equus Beds aquifer near Burrton, Kansas, 2001-2012

16. Map showing average nitrite plus nitrate concentrations in the study area, 2006-2012, south-central Kansas, in shallow wells and deep wells.

17. Graph showing duration curves of computed dissolved arsenic concentrations, 1999-2012, Little Arkansas River near Halstead and near Sedgwick, Kansas.

18. Map showing average arsenic concentrations in the study area, 2006-2012, south-central Kansas, in shallow wells and deep wells

19. Map showing average dissolved iron concentrations in the study area, 2006-2012, south-central Kansas, in shallow wells and deep wells

20. Map showing average dissolved manganese concentrations in the study area, 2006-2012, south-central Kansas, in shallow wells and deep wells.

21. Graph showing duration curves of computed atrazine concentrations, 1999-2012, Little Arkansas River near Halstead and near Sedgwick, Kansas...

22. Graph showing duration curves of computed fecal coliform bacteria densities, 1999-2012, Little Arkansas River near Halstead and near Sedgwick, Kansas.

23. Graph showing duration curves of computed Escherichia coli bacteria densities, 1999-2012, Little Arkansas River near Halstead and near Sedgwick, Kansas.

24. Graph showing chloride, atrazine, and arsenic concentration plots and recharge activity associated with RRW-1 during 2002 to 2012, south-central Kansas... 
25. Graph showing chloride, atrazine, and arsenic concentration plots during 2002 to 2012 and recharge activity associated with RRW-2, south-central Kansas......................57

26. Graph showing chloride, atrazine, and arsenic concentration plots during 2002 to 2012 and recharge activity associated with RRW-3, south-central Kansas....................58

27. Graph showing chloride, atrazine, and arsenic concentration plots during 2002 to 2012 and recharge activity associated with RRW-4, south-central Kansas......

28. Graph showing chloride, atrazine, and arsenic concentration plots during 2002 to 2012 and recharge activity associated with RB-1, south-central Kansas

29. Graph showing chloride, atrazine, and arsenic concentration plots during 2002 to 2012 and recharge activity associated with RB-2, south-central Kansas

1-1. Graph showing median relative percentage differences for replicate samples collected during 1995-2004

1-2. Graph showing detection frequency of water-quality constituents in blank samples collected during 1995-2004

\section{Tables}

1. Number of days when water diversion permit conditions were met, Little Arkansas River at Highway 50 near Halstead, Kansas, 1995-2012.

2. Summary of constituents of concern for all Equus groundwater samples ......................16

3. Summary of selected water-quality data from surface-water samples collected from February 1995 through December 2012 as a part of the Equus Beds Groundwater Recharge Project, south-central Kansas...

4. Summary of selected water-quality data from groundwater samples collected from November 2001 through December 2012 as a part of the Equus Beds Groundwater Recharge Project at shallow areal assessment index wells, deep areal assessment index wells, aquifer storage and recovery (ASR) Phase I source sites, ASR Phase I shallow monitoring wells, and ASR Phase I deep monitoring wells, south-central Kansas.

5. Comparison of water-quality data from index wells obtained during 2001 to 2006 to data obtained during 2007 to 2012.

1-1. Data-collection sites for Equus Beds Groundwater Recharge Project, south-central Kansas, 1995-2012. 


\section{Conversion Factors}

[Inch/Pound to Internation System of Units]

\begin{tabular}{|c|c|c|}
\hline Multiply & By & To obtain \\
\hline \multicolumn{3}{|c|}{ Length } \\
\hline foot $(\mathrm{ft})$ & 0.3048 & meter $(\mathrm{m})$ \\
\hline micrometer $(\mu \mathrm{m})$ & 0.000039 & inch (in.) \\
\hline mile (mi) & 1.609 & kilometer $(\mathrm{km})$ \\
\hline \multicolumn{3}{|c|}{ Area } \\
\hline square mile (mi2) & 2.590 & square kilometer $\left(\mathrm{km}^{2}\right)$ \\
\hline \multicolumn{3}{|c|}{ Volume } \\
\hline gallon (gal) & 0.003785 & cubic meter $\left(\mathrm{m}^{3}\right)$ \\
\hline milliliter $(\mathrm{mL})$ & 0.033814 & ounce (oz) \\
\hline million gallons (Mgal) & 3,785 & cubic meter $\left(\mathrm{m}^{3}\right)$ \\
\hline \multicolumn{3}{|c|}{ Flow rate } \\
\hline cubic foot per second $\left(\mathrm{ft}^{3} / \mathrm{s}\right)$ & 0.02832 & cubic meter per second $\left(\mathrm{m}^{3} / \mathrm{s}\right)$ \\
\hline million gallons per day (Mgal/d) & 0.04381 & cubic meters per second $\left(\mathrm{m}^{3} / \mathrm{s}\right)$ \\
\hline \multicolumn{3}{|c|}{ Hydraulic gradient } \\
\hline foot per mile $(\mathrm{ft} / \mathrm{mi})$ & 0.1894 & meter per kilometer $(\mathrm{m} / \mathrm{km})$ \\
\hline
\end{tabular}

Temperature in degrees Celsius $\left({ }^{\circ} \mathrm{C}\right)$ may be converted to degrees Fahrenheit $\left({ }^{\circ} \mathrm{F}\right)$ as follows:

$$
{ }^{\circ} \mathrm{F}=\left(1.8 x^{\circ} \mathrm{C}\right)+32 \text {. }
$$

Temperature in degrees Fahrenheit $\left({ }^{\circ} \mathrm{F}\right)$ may be converted to degrees Celsius $\left({ }^{\circ} \mathrm{C}\right)$ as follows:

$$
{ }^{\circ} \mathrm{C}=\left({ }^{\circ} \mathrm{F}-32\right) / 1.8 \text {. }
$$

\section{Datum}

Vertical coordinate information is referenced to the North American Vertical Datum of 1988 (NAVD 88) or to the National Geodetic Vertical Datum of 1929 (NGVD29)

Horizontal coordinate information is referenced to the North American Datum of 1983 (NAD 83).

Altitude, as used in this report, refers to distance above the vertical datum.

\section{Supplemental Information}

Water-quality constituents described in this report were measured or estimated in milligrams per liter (mg/L), micrograms per liter $(\mu \mathrm{g} / \mathrm{L})$, microsiemens per centimeter at 25 degrees Celsius $\left(\mu \mathrm{S} / \mathrm{cm}\right.$ at $\left.25^{\circ} \mathrm{C}\right)$, colonies per 100 milliliters (col/100 mL), colony-forming units per 100 milliliters (CFU/100 mL), plaques per 100 milliliters (pfu/100 mL), and picocuries per liter (pCi/L). 


\section{Abbreviations}

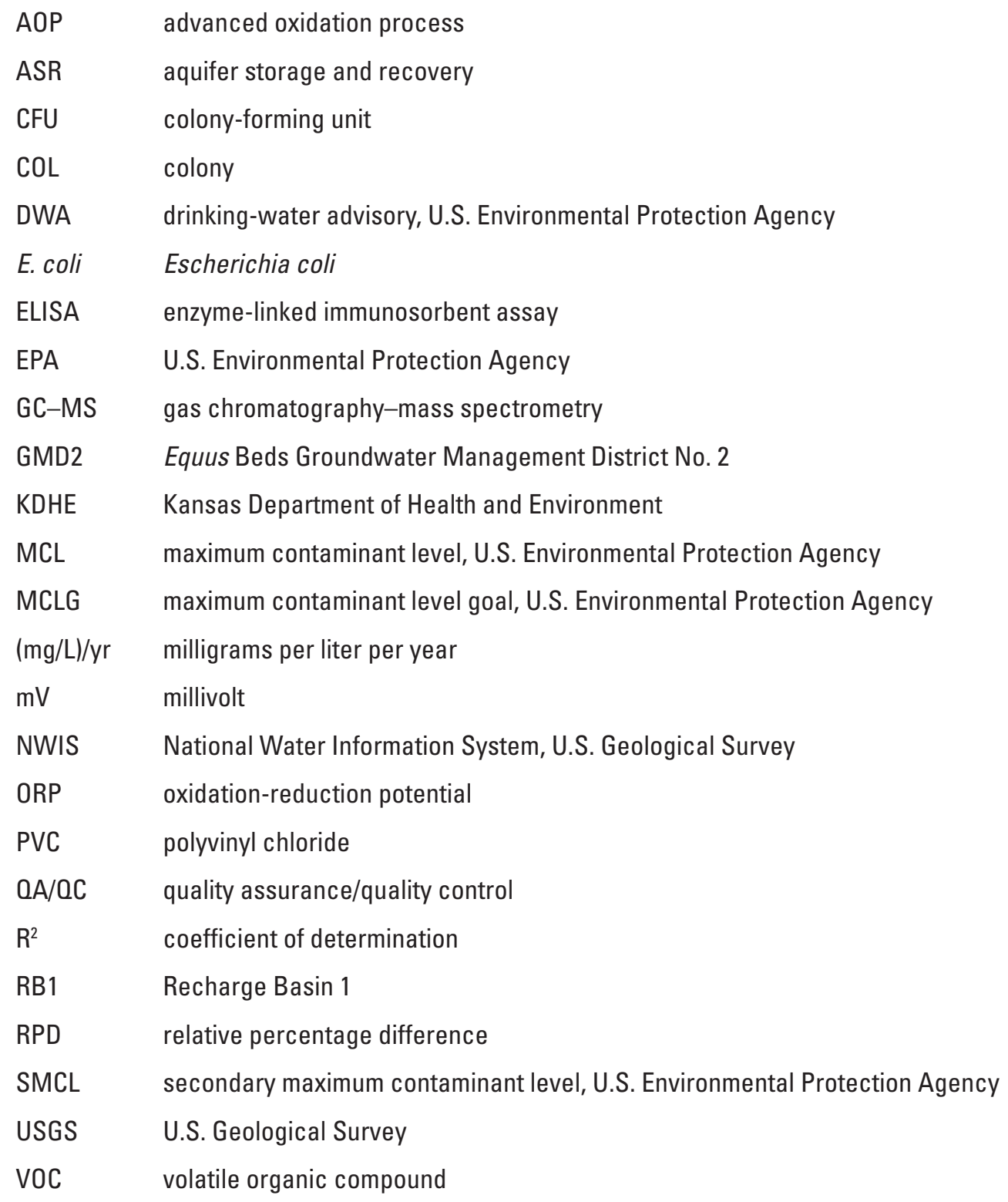





\title{
Water Quality of the Little Arkansas River and Equus Beds Aquifer Before and Concurrent with Large-Scale Artificial Recharge, South-Central Kansas, 1995-2012
}

\author{
By Daniel J. Tappa, Jennifer L. Lanning-Rush, Brian J. Klager, Cristi V. Hansen, and Andrew C. Ziegler
}

\section{Abstract}

The city of Wichita artificially recharged about 1 billion gallons of water into the Equus Beds aquifer during 2007-2012 as part of Phase I recharge of the Artificial Storage and Recovery project. This report, prepared in cooperation by the U.S. Geological Survey and the city of Wichita, Kansas, summarizes Little Arkansas River (source-water for artificial recharge) and Equus Beds aquifer water quality before (1995-2006) and during (2007-2012) Artificial Storage and Recovery Phase I recharge. Additionally, aquifer water-quality distribution maps are presented and water-quality changes associated with Phase I recharge timing are described. Water quality within the Little Arkansas River was defined using measured and regression-computed data from discrete samples and two real-time surface water-quality sites. Water quality in the Equus Beds aquifer was defined using samples collected at 38 areal assessment index well sites (each site with one deep and one shallow well), 7 diversion well sites, 13 background wells, 9 Artificial Storage and Recovery prototype wells, and 66 Artificial Storage and Recovery Phase I and Phase II monitoring wells. Constituents of concern for artificial recharge are major ions (sulfate, chloride), nutrients (nitrite plus nitrate), trace elements (arsenic, iron, and manganese), triazine herbicides (atrazine), and fecal indicator bacteria.

Sulfate concentrations in water samples from the Little Arkansas River during 1995-2012 rarely exceeded the Federal secondary maximum contaminant level of 250 milligrams per liter. Sulfate concentrations during 2001-2012 exceeded the secondary maximum contaminant level in groundwater in 18.7 percent of the samples from areal assessment index wells in the shallow (less than or equal to 80 feet below land surface) parts of the aquifer and in 12.9 percent of the samples from areal assessment index wells in the deep parts of the aquifer. Computed chloride concentrations in the Little Arkansas River near Halstead during 1999-2012 exceeded the Federal secondary maximum contaminant level of 250 milligrams per liter about 20 percent of the time (primarily during low-flow conditions). Chloride concentrations in groundwater during 2001-2012 exceeded 250 milligrams per liter in 5.6 percent of the samples from shallow areal assessment index wells and 7.4 percent of the samples from deep areal assessment index wells, primarily near Burrton, Kansas, and along the Arkansas River.

Nutrients, such as nitrite plus nitrate, are a water-quality concern because of the predominant agricultural land use in the 189-square-mile study area. Almost all (more than 99.6 percent) nitrite plus nitrate concentrations in water samples collected at the two surface water monitoring sites on the Little Arkansas River from 1995 through 2012 were less than the Federal maximum contaminant level of 10 milligrams per liter for nitrate. Nitrite plus nitrate concentrations in groundwater samples during 2001-2012 exceeded the maximum contaminant level in 15.7 percent of the samples from shallow areal assessment index wells. Nitrite plus nitrate concentrations were minimal in the deeper parts of the aquifer.

Several trace elements frequently exceeded drinkingwater criteria, including arsenic, iron, and manganese. Computed arsenic concentrations in the Little Arkansas River at Highway 50 near Halstead, Kans., during 1995-2012 exceeded the Federal drinking-water maximum contaminant level of 10 micrograms per liter $(\mu \mathrm{g} / \mathrm{L})$ about 19 percent of the time, primarily during low-flow conditions. In shallow groundwater during 2001-2012, arsenic concentrations exceeded the maximum contaminant level in 11.9 percent of the samples from the areal assessment index wells, whereas for the deep areal assessment index wells, arsenic concentrations exceeded the maximum contaminant level in 34.6 percent of the samples. Iron and manganese concentrations also exceeded Federal drinking-water criteria in surface and groundwater. In the Little Arkansas River, dissolved iron concentrations exceeded the Federal secondary maximum contaminant level of 300 micrograms per liter during 1995-2012 in about 5 percent of the samples, and manganese concentrations exceeded the Federal secondary maximum contaminant level of 50 micrograms per liter in about 50 percent of the samples. In the shallow parts of the aquifer during 2001-2012, iron concentrations exceeded the Federal secondary maximum contaminant level in 37.2 percent of the samples from areal assessment index wells, whereas manganese concentrations in the shallow areal assessment index wells exceeded the Federal 
secondary maximum contaminant level in 54.6 percent of the samples. In the deep parts of the aquifer, iron concentrations exceeded the secondary maximum contaminant level in 44.6 percent of the areal assessment index well samples, and manganese concentrations exceeded the secondary maximum contaminant level in 91.8 percent of the samples. Areas with the largest concentrations of iron and manganese corresponded to areas with the largest water-level declines that have subsequently recovered and the areas with the more chemically reducing conditions.

Computed concentrations of atrazine in the Little Arkansas River near Sedgwick during 1999-2012 exceeded the Federal maximum contaminant level of 3.0 micrograms per liter about 28.0 percent of the time, mostly during the late spring to early fall. Atrazine was detected in about 57.0 percent of the samples collected from shallow areal assessment index wells and 26.0 percent of the samples collected from the deep areal assessment index wells during 2001-2012, which indicates infiltration from field applications to the groundwater; however, all concentrations were less than the Federal maximum contaminant level.

Large densities of coliform bacterial indicators (total coliform, fecal coliform, and E. coli) were detected in most water samples from the Little Arkansas River. Total coliform detections exceeded the Federal maximum contaminant level goal for drinking water of 0 colonies in water samples during 2001-2012 from 24.7 percent of the shallow areal assessment index wells and in 12.4 percent of the deep areal assessment index wells. Many of these detections were in the first samples collected from the wells after they were developed, indicating that at least some of these detections may be related to drilling. Almost all wells sampled for this study had at least 1 sample with a total coliform detection; however, the median densities for most of these wells were less than 1 colony per 100 milliliters. Viral indicators (Clostridium perfringens and E. coli coliphage) were present in samples from the Little Arkansas River during storm runoff but were not detected in any samples of groundwater. These data indicated that natural infiltration of water through the soil removes bacterial and viral indicator organisms.

Constituents and physical properties of interest for each of the shallow and deep areal assessment index wells include arsenic, chloride, iron, manganese, nitrite plus nitrate, oxidation-reduction potential, specific conductance, and sulfate. As a group, all of the constituents of interest except chloride, arsenic, and oxidation-reduction potential increased in concentration or value from the 2001 to 2006 period to the 2007 to 2012 period in the areal assessment index well network. The median values for constituent well averages increased for sulfate, chloride, iron, manganese, and specific conductance from the first period to the second, while nitrite plus nitrate, arsenic, and oxidation-reduction potential decreased.

Recharge activities at Phase I recharge wells have not resulted in substantial effects on groundwater quality in the area, likely because the total amount of water recharged is relatively small ( 1 billion gallons) compared to aquifer storage volume (greater than 990 billion gallons in winter 2012). The eastward movement of the Burrton chloride plume is likely being slowed by a line of recharge locations associated with Phase I; however, the line depicting average chloride concentrations in deep groundwater during 2006-2012 still advanced to less than one half mile from the central part of the study area. Water-quality constituents of concern outlined here have not increased substantially, and are likely more affected by climatological (natural recharge by precipitation) and natural (geochemical oxidation/reduction, metabolic and decay rates) processes than artificial recharge. Arsenic remains a water-quality constituent of concern because of natural and continued persistence of concentrations exceeding the Federal maximum contaminant level of 10 micrograms per liter, especially in the deeper parts of the Equus Beds aquifer.

\section{Introduction}

A cooperative study was done by the U.S. Geological Survey (USGS) and the city of Wichita, Kansas, to update Ziegler and others (2010), a report describing Equus Beds aquifer and Little Arkansas River water-quality data during 1995 through 2005. This report describes additional data collected during 2006 through 2012 as a continuation of the study described in Ziegler and others (2010) and summarizes Little Arkansas River (source-water for artificial recharge) and Equus Beds aquifer water quality. Including recent (2006-12) data in this report allows for additional analysis and statistical techniques, including trend analyses that were not used in Ziegler and others (2010). Some parts of this report are reproduced verbatim from Ziegler and others (2010).

\section{Equus Beds Aquifer Artificial Recharge}

The city of Wichita implemented the Equus Beds Groundwater Recharge Demonstration Project in 1995 to investigate the feasibility of using Little Arkansas River water to artificially recharge the aquifer. Ziegler and others (1999) identified the water-quality constituents of concern and described the water quality compatibility between the Little Arkansas River and the Equus Beds aquifer. The report (Ziegler and others, 1999) indicated that the Little Arkansas River and Equus Beds aquifer have compatible water quality and Ziegler and others (2001) documented minimal changes to the aquifer water quality after 3 years of artificial recharge associated with the Groundwater Recharge Demonstration Project. Primary constituents of concern identified by Ziegler and others (1999) were sodium, chloride, nitrite plus nitrate (hereafter referred to as nitrate), iron, manganese, atrazine, and total coliform bacteria. In 2001, arsenic was added to the constituents of concern list after the U.S. Environmental Protection Agency (EPA) lowered the maximum contaminant level (MCL) from 50 to 10 micrograms per liter $(\mu \mathrm{g} / \mathrm{L}$; Ziegler and others, 2001). A thorough description of Groundwater 
Recharge Demonstration Project site locations and permit regulations for recharge operations associated with the Equus Beds Groundwater Recharge Demonstration Project can be found in Ziegler and others (1999), Ziegler and others (2010), and Garinger and others (2011). Additionally, Ziegler and others (2010) highlight several related water-quality studies.

After successful implementation of artificial recharge of the Equus Beds aquifer during the Groundwater Recharge Demonstration Project, the city of Wichita moved forward with plans for aquifer storage and recovery (ASR) Phase I, a large-scale recharge operation. Phase I recharge activity began in 2007 with water being injected at four wells (RRW-1RRW-4; fig. 1) and 2 recharge basins (RB-1 and RB-2; fig. 1) and recharge activity continued through 2012 with intermittent pauses as a result of low flows on the Little Arkansas River. For Phase I recharge, stream water was diverted directly from the Little Arkansas River and indirectly through streambank diversion wells when base flow was exceeded at the streamflow gaging station near Halstead, Kans. (Garinger, 2011; fig. 1; table 1). Directly diverted stream water went through a treatment process to reduce sediment and remove organic materials before being recharged to the aquifer through RB-1 and RB-2; whereas water pumped from streambank diversion wells did not receive additional treatment before being recharged to the aquifer through any of the Phase I injection wells or recharge basins (Garinger, 2011).

A summary table of gallons of water recharged for each month during Phase I is available online (http://ks.water.usgs. gov/water-recharge\#phase1, June 2014). Total recharged water at Phase I sites was about 1 billion gallons (gal) between 2007 and 2012; however, from November 2010 to March 2012, no recharge occurred because of extended drought conditions in south-central Kansas. Phase I has an operational capacity of 10 million gallons per day (Mgal/day), whereas Phase II (operational in April 2013) has a capacity to recharge $30 \mathrm{Mgal} /$ day.

\section{Description of Study Area and Background}

The study area encompasses approximately 189 square miles $\left(\mathrm{mi}^{2}\right)$ in south-central Kansas, northwest of Wichita in Harvey and Sedgwick Counties (fig. 1). The area is bounded by the Arkansas River to the southwest and the Little Arkansas River to the northeast (fig. 1). The Little Arkansas River drains an area of about $1,200 \mathrm{mi}^{2}$ of primarily agricultural land. Crops produced include corn, sorghum, soybeans, and wheat. Common agricultural chemicals applied to these crops include fertilizers and herbicides, such as alachlor and atrazine. Livestock raised in the area include cattle and hogs (Kansas Department of Agriculture, 2006).

The study area is underlain by the Equus Beds aquifer, which is considered a part of the larger High Plains aquifer (fig. 1). The aquifer is named for Pleistocene horse fossils found in the aquifer sediments. The Equus Beds aquifer is about 300 feet (ft) thick with the deepest parts near the McPherson Channel (bedrock low), and consists of sand and gravel alluvial deposits interbedded with clay and silt that lay on top of the shale in the Wellington Formation (fig. 2; Ziegler and others, 2010). A more detailed description of the study area geology is presented in Ziegler and others (2010).

The aquifer is an important source of groundwater because of its water quality, shallow depth to the water table, and large saturated thickness (Williams and Lohman, 1949). The general direction of groundwater movement within the study area is west to east (Aucott and others, 1998; Hansen and others, 2014) except where the hydraulic gradient is altered by pumping wells and near a low-head dam on the Little Arkansas River at Halstead, Kansas (fig. 3). The well field, developed by the city of Wichita in the Equus Beds aquifer during the 1940s and completed in the 1950s, is one of the primary sources of water for the city and the surrounding area (within the central part of the study area, fig. 1). Numerous irrigation wells also withdraw water from the aquifer within the boundaries of Equus Beds Groundwater Management District Number 2 (GMD2; Equus Beds Groundwater Management District No. 2, 1990).

After an extended period of less than average precipitation (referred hereafter as drought) during the 1950s (fig. 4A) the Bureau of Reclamation constructed the Cheney Dam, and the city of Wichita began using water from Cheney Reservoir (partially shown southwest of study area, fig. 1) in 1965 to supplement its supply from the Equus Beds aquifer. The proportion of the water supply obtained from Cheney Reservoir increased from 20 percent in 1965 to 44 percent in 1994, and from 1995 through 2012, water from Cheney Reservoir ranged from 51 to 70 percent of Wichita's total water supply (fig. $4 B$ ). The increased reliance on surface water from Cheney Reservoir was part of Wichita's Integrated Local Water Supply Plan implemented in 1993 (Warren and others, 1995; City of Wichita, written commun., 2000). This plan was implemented to ensure that the city's water-supply needs would be met through 2050 by promoting conservation, increasing water use from Cheney Reservoir, and decreasing pumping from city wells in the Equus Beds well field. The plan also called for investigating Equus Beds ASR using excess water from the Little Arkansas River, which is currently (2015) an ongoing operation. Phase I recharge of the ASR project began in 2007 and continued through 2012 (fig. 1), whereas Phase II of the ASR project (additional recharge and diversion sites, new pre-recharge surface water treatment facility) became operational in 2013. As of 2013, Phase I and Phase II are coexisting operations.

Substantial water-level declines in the Equus Beds aquifer have resulted from pumping groundwater for agricultural and municipal needs as well as periodic drought conditions. The lowest water levels were recorded in 1993 and were as much as $50 \mathrm{ft}$ lower than predevelopment (1940) water levels in some locations (Hansen and Aucott, 2001, 2004; Hansen, 2007). Water-level declines caused concern about the adequacy of Wichita's future water supply. Saltwater migration into the aquifer is an additional issue. Sources of saltwater include the Arkansas River, oil-field brines that leaked from surface disposal pits or injection wells in the Burrton oil-field area 


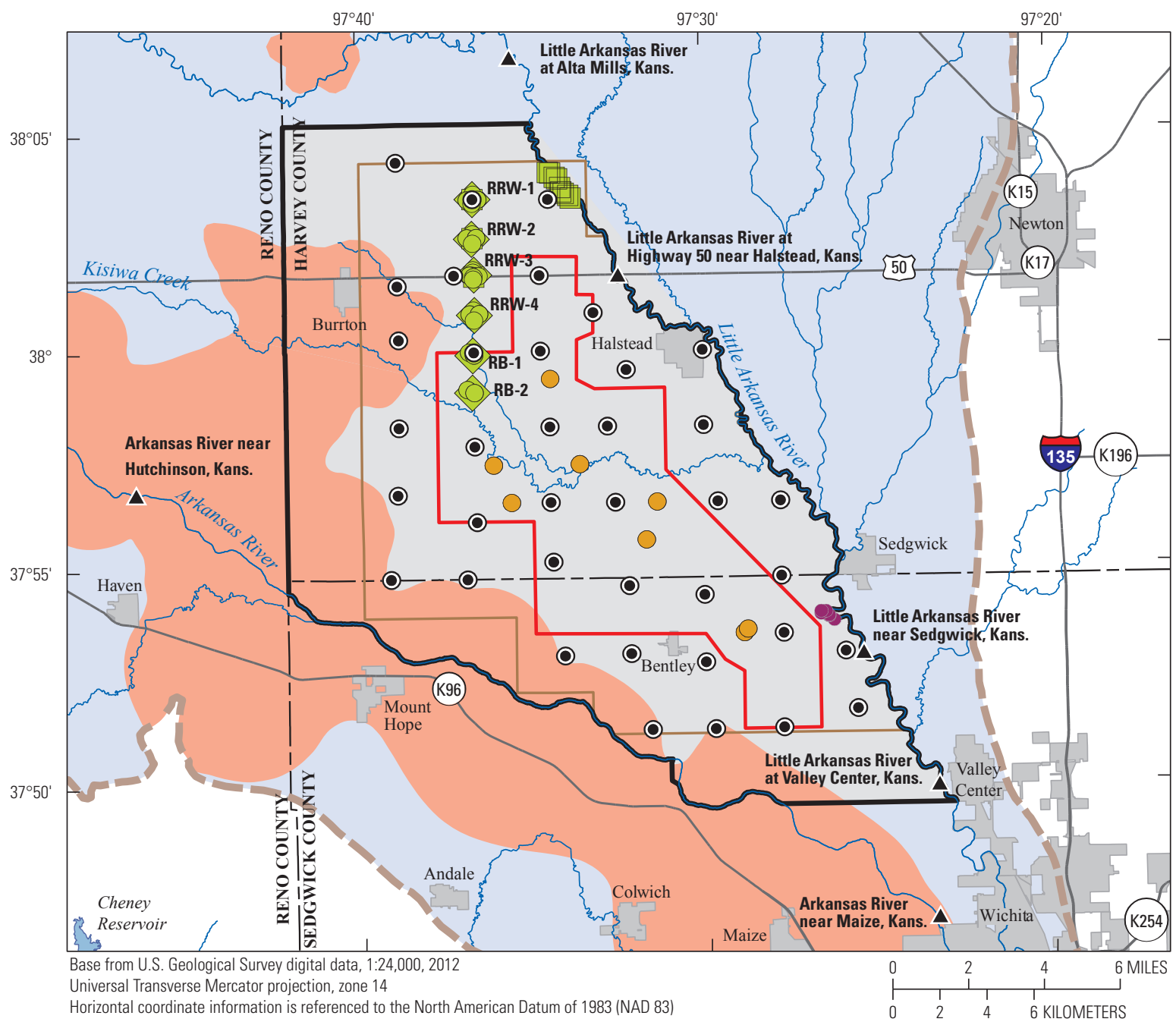

EXPLANATION

Chloride concentrations from wells where well depth is greater than $\mathbf{8 0}$ feet below the landsurface in this approximate area exceed the U.S. Environmental Protection Agency's National secondary drinking water regulation of 250 milligrams per liter

Study area

Approximate extent of High Plains aquifer

Boundary of basin storage area

Boundary of central part of the study area

Approximate boundary of Equus Beds aquifer (modified from Juracek and Hansen, 1995; Stulken and other, 1985; Stamel, 1967)
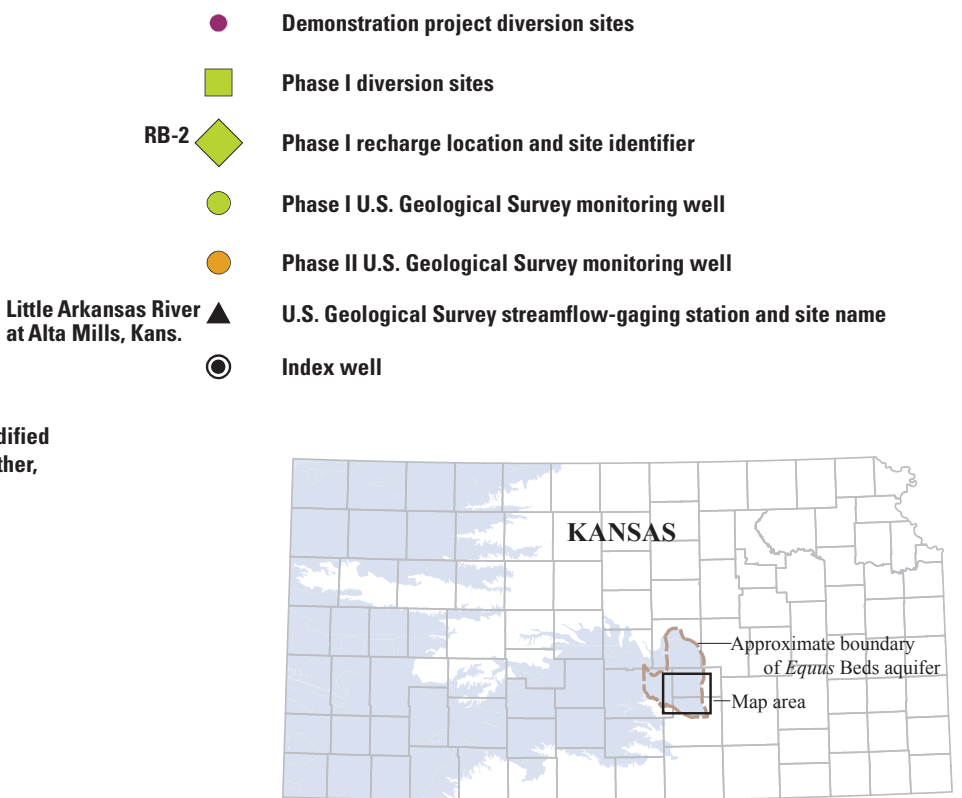

Figure 1. Location of the study area near Wichita, south-central Kansas. 
Table 1. Number of days when water diversion permit conditions were met, Little Arkansas River at Highway 50 near Halstead, Kansas, 1995-2012.

$\left[\mathrm{ft}^{3} / \mathrm{s}\right.$, cubic foot per second; recharge permit conditions for streamflow diversion set by the Kansas Department of Agriculture, Division of Water Resources, January 1995-December 2005: April 1 through September 30 streamflow must exceed $42 \mathrm{ft}^{3} / \mathrm{s}$, October 1 through March 31 streamflow must exceed $20 \mathrm{ft}^{3} / \mathrm{s}$; January 2006-present (Phase I): April 1 through September 30 streamflow must exceed $57 \mathrm{ft} / 3 / \mathrm{s}$, October 1 through March 31 streamflow must exceed $20 \mathrm{ft}^{3} / \mathrm{s}$; shading pertains to number of annual days exceeding current permit conditions]

\begin{tabular}{|c|c|c|c|}
\hline Year & $\begin{array}{c}\text { Number of days when streamflow } \\
\text { met permit conditions }\end{array}$ & $\begin{array}{c}\text { Number of days when streamflow } \\
\text { exceeded } 70 \mathrm{ft}^{3} / \mathrm{s}\end{array}$ & $\begin{array}{c}\text { Number of days when streamflow } \\
\text { exceeded } 100 \mathrm{ft}^{3} / \mathrm{s}\end{array}$ \\
\hline 1995 & 99 & 72 & 62 \\
\hline 1997 & 270 & 97 & 83 \\
\hline 1998 & 261 & 161 & 121 \\
\hline 2001 & 171 & 103 & 88 \\
\hline 2002 & 110 & 57 & 47 \\
\hline 2003 & 161 & 89 & 71 \\
\hline 2004 & 159 & 67 & 49 \\
\hline 2008 & 286 & 136 & 95 \\
\hline 2009 & 280 & 113 & 85 \\
\hline 2010 & 170 & 58 & 46 \\
\hline 2011 & 49 & 16 & 11 \\
\hline 2012 & 41 & 24 & 18 \\
\hline Average & 173 & 88 & 69 \\
\hline Median & 164 & 93 & 76 \\
\hline Standard deviation & 93 & 46 & 36 \\
\hline 10th percentile & 47 & 22 & 16 \\
\hline
\end{tabular}

northwest of the study area (fig. 1), municipal wastewater facility discharges, industrial discharges, and mineralized water from the underlying Wellington Formation (Ziegler and others, 1999; Whittemore, 2007).

Groundwater levels in the shallow part of the aquifer increased by as much as $25 \mathrm{ft}$ in some areas by the summer of 2012 compared to 1993 levels; however, outside the central part of the study area, specifically in the north-central part, water levels have decreased since 1993 (fig. 5; Hansen and others, 2014). These water-level decreases are likely a result of increased irrigation-related pumping for agricultural purposes during 2011 through 2012 drought conditions (figs. $4 A$ and $4 B$ ). Overall, the summer 2012 groundwater levels remain substantially lower than predevelopment (1940) water levels (fig. 6; Hansen and others, 2014). By the summer of 2012, water storage in the central part of the study area increased by about 40 percent since 1992 likely because of a combination of natural recharge of above normal precipitation (19932012), decreased aquifer pumping by the city of Wichita, and implementation of artificial recharge (Hansen and others, 2014). Other factors contributing to aquifer increases since 1993 include subsurface inflow, streamflow losses, and irrigation return flow (Myers and others, 1996). Hansen and others (2014) estimated the winter 2012 total aquifer storage volume in the study area to be greater than 3 million acre-feet (about 990 billion gallons).

Water quality in the study area is controlled by the geology of the underlying bedrock and aquifer materials; hydraulic permeability (porosity) and geochemical (oxidation and reduction) properties of the aquifer; and effects related to past oil and gas activities, and agriculture. Water-quality changes were anticipated in the Equus Beds aquifer with the implementation of full-scale artificial recharge. Increased water levels from artificial recharge were expected to slow the saltwater migration from the northwest and south of the study area, which could potentially limit further chloride migration and improve aquifer water quality (fig. 1). 


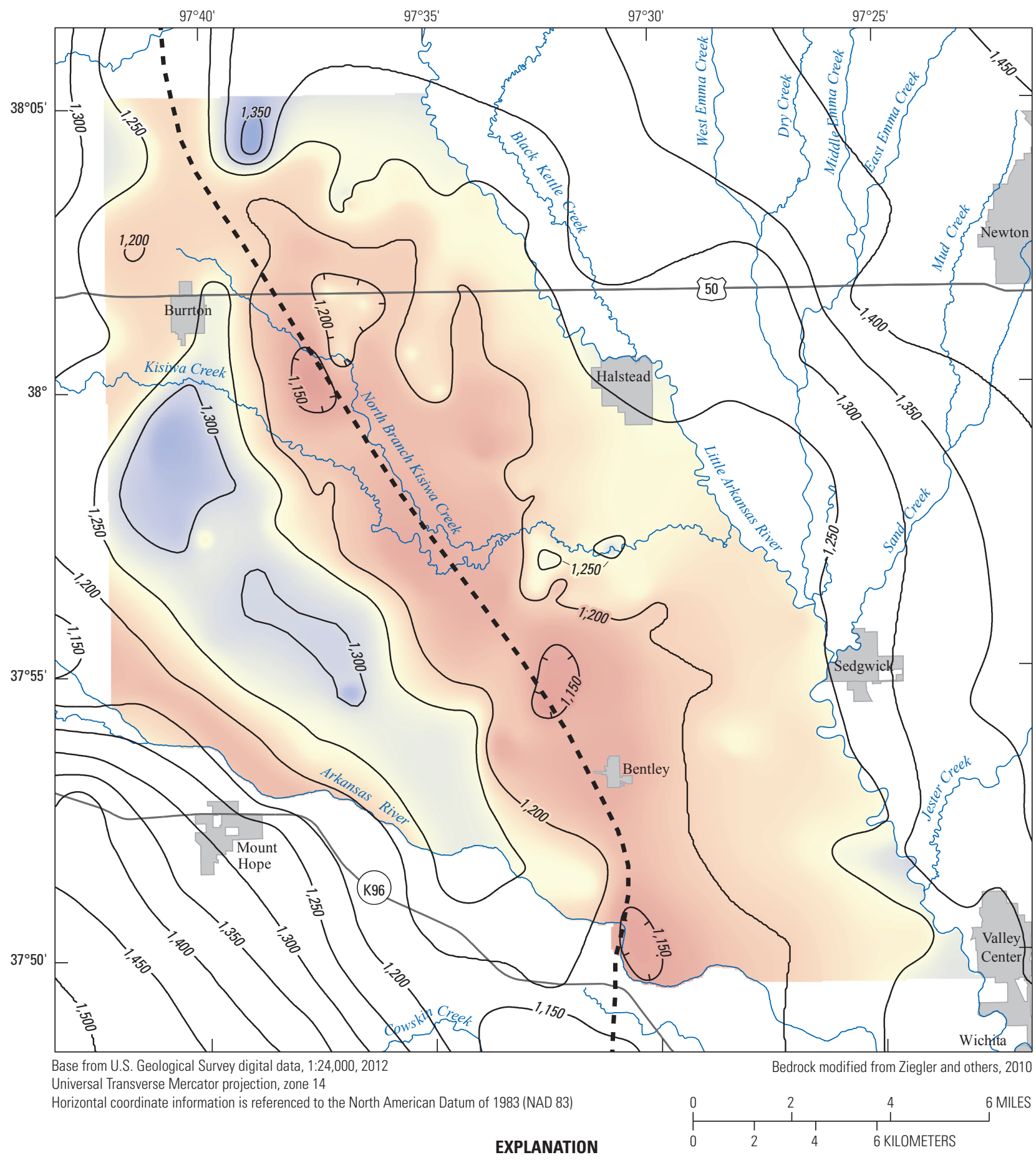

Bedrock surface in the study area. Datum is National Geodetic Vertical Datum of 1929 (NGVD)
- 1,355
1,250
1,135

\section{- - Approximate location of bedrock low (McPherson Channel)}

- Bedrock contour-Shows altitude of bedrock surface. Contour interval 50 feet. Datum is NGVD 29

$\square$ Bedrock contour low-Shows altitude of bedrock surface. Contour interval 50 feet. Datum is NGVD 29

Figure 2. Bedrock altitude in and near the study area, south-central Kansas. 


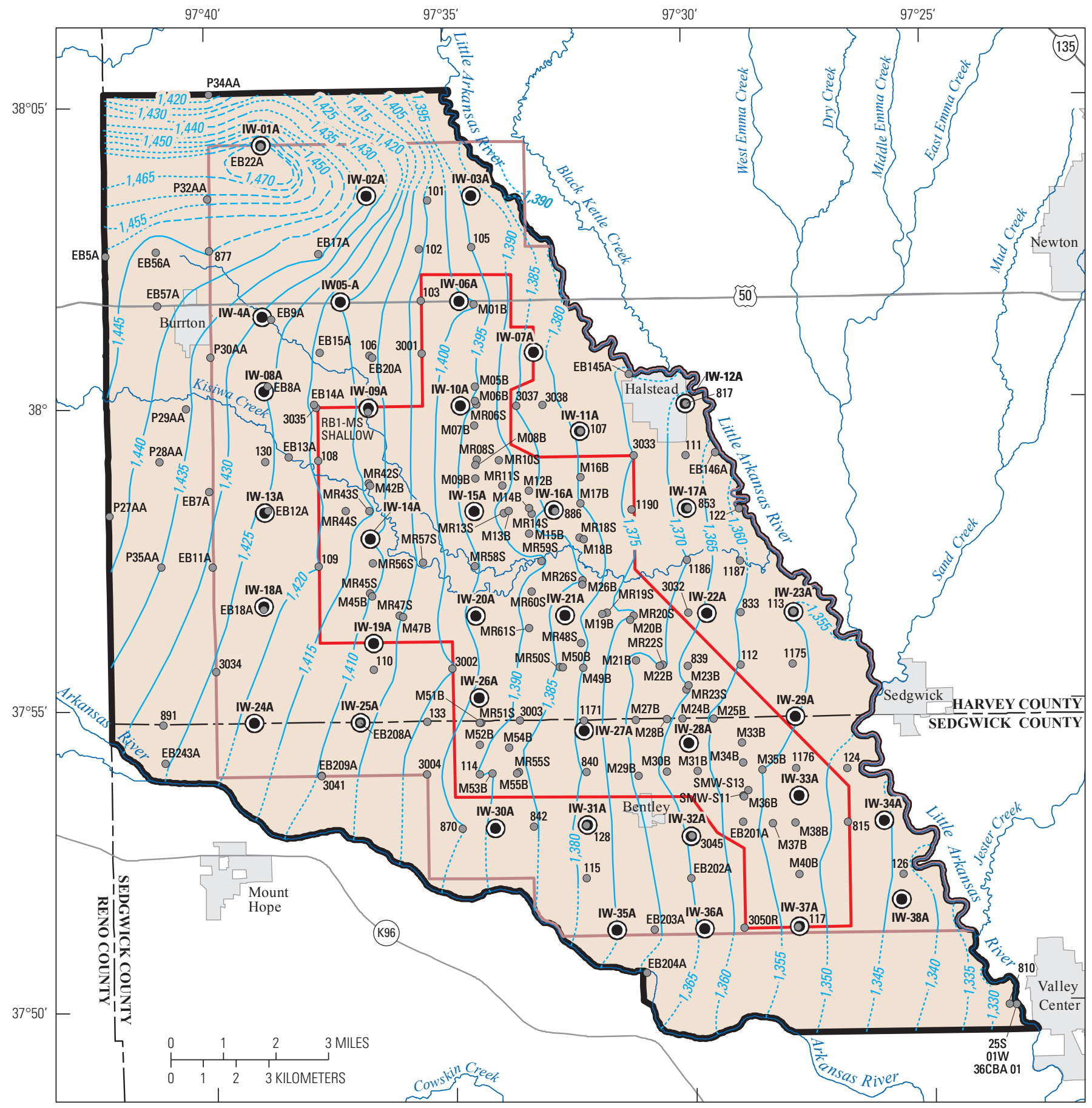

Base from U.S. Geological Survey digital data, 1:24,000, 2012

Modified from Hansen and others, 2014 Universal Transverse Mercator projection, zone 14

Horizontal coordinate information is referenced to the North American Datum of 1983 (NAD 83)

\section{EXPLANATION}
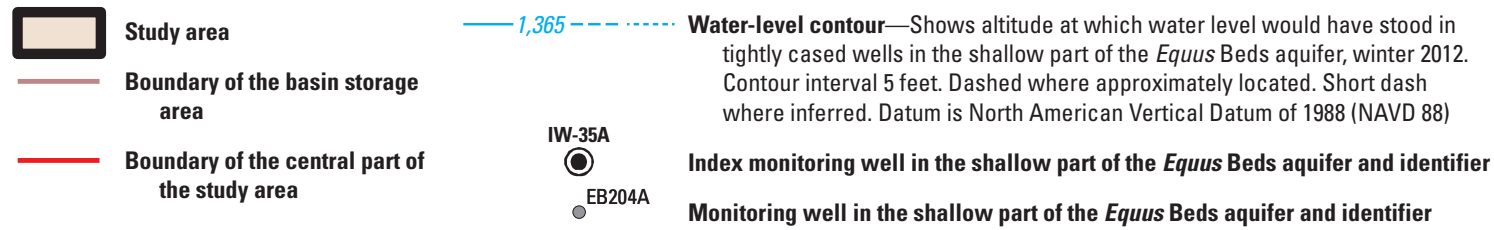

Figure 3. Static water-level altitudes in the shallow part of the Equus Beds aquifer, winter 2012, south-central Kansas. 


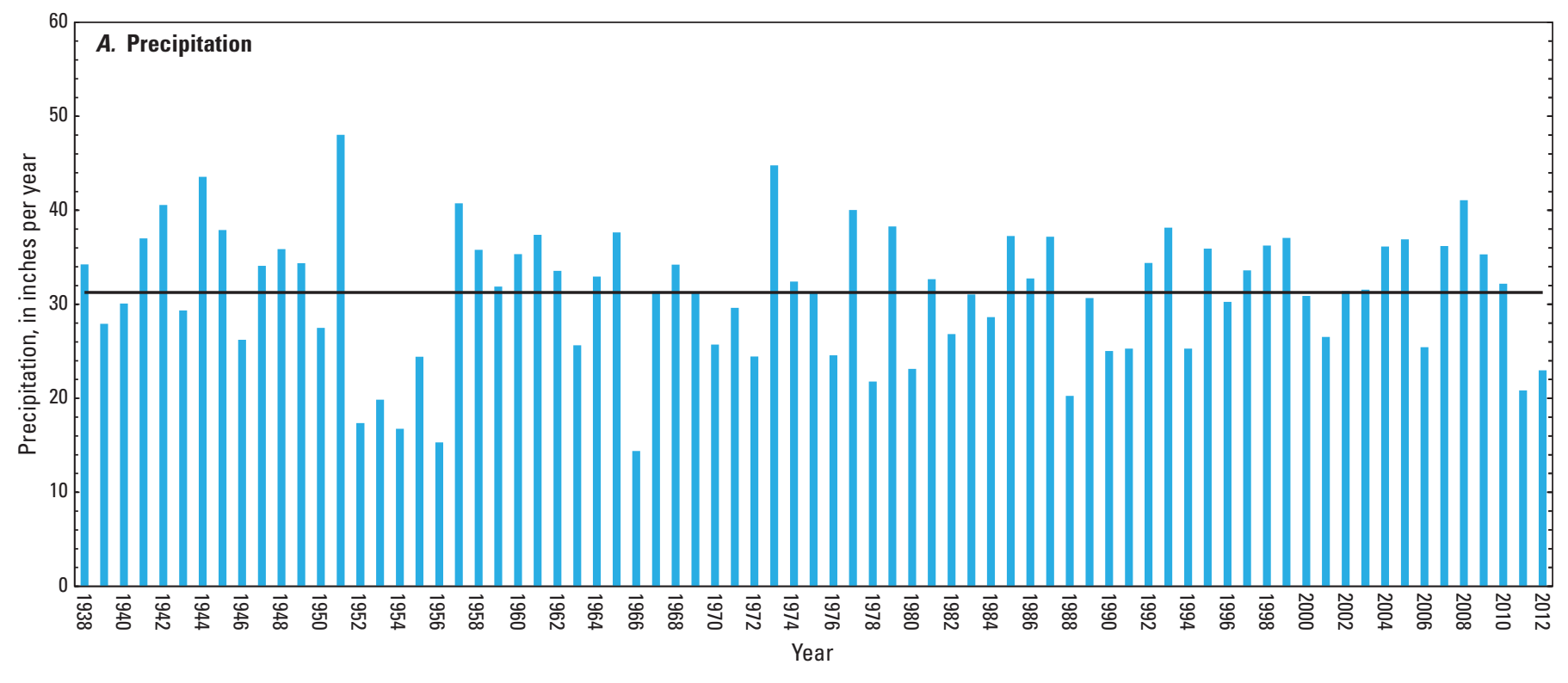

EXPLANATION

Annual average precipitation-Average precipitation includes precipitation data from weather stations in or near Bentley, Halstead, Hutchinson, Mount Hope, Newton, Sedgwick, and Wichita, Kansas

\section{- 1938-2012 average precipitation (31.26 inches)}

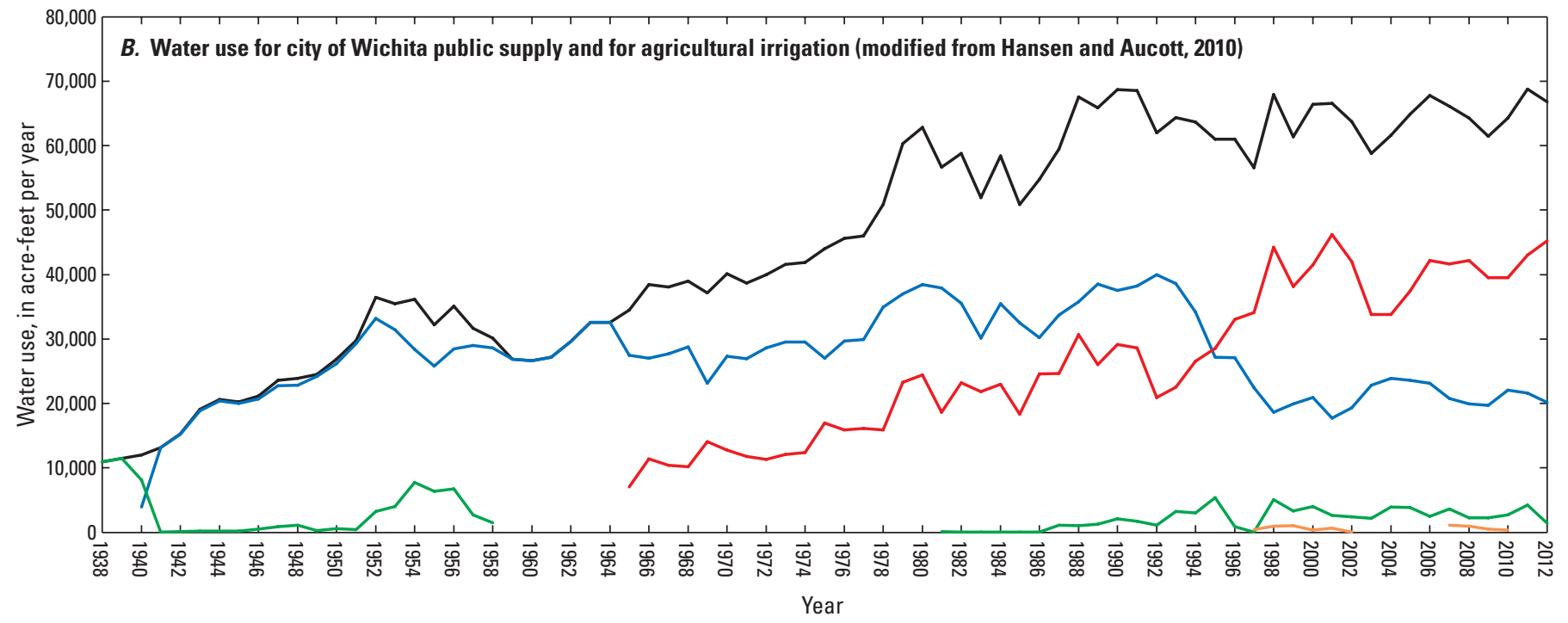

EXPLANATION

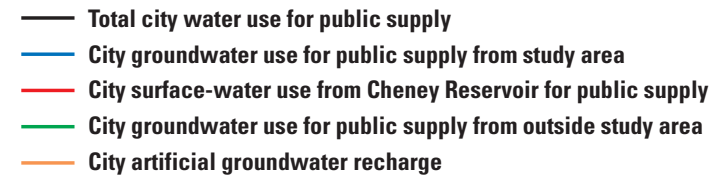

Figure 4. Average annual precipitation in and near the study area, $A$; and water use for the city of Wichita public supply and agricultural irrigation, $B$; 1938-2012, south-central Kansas. 


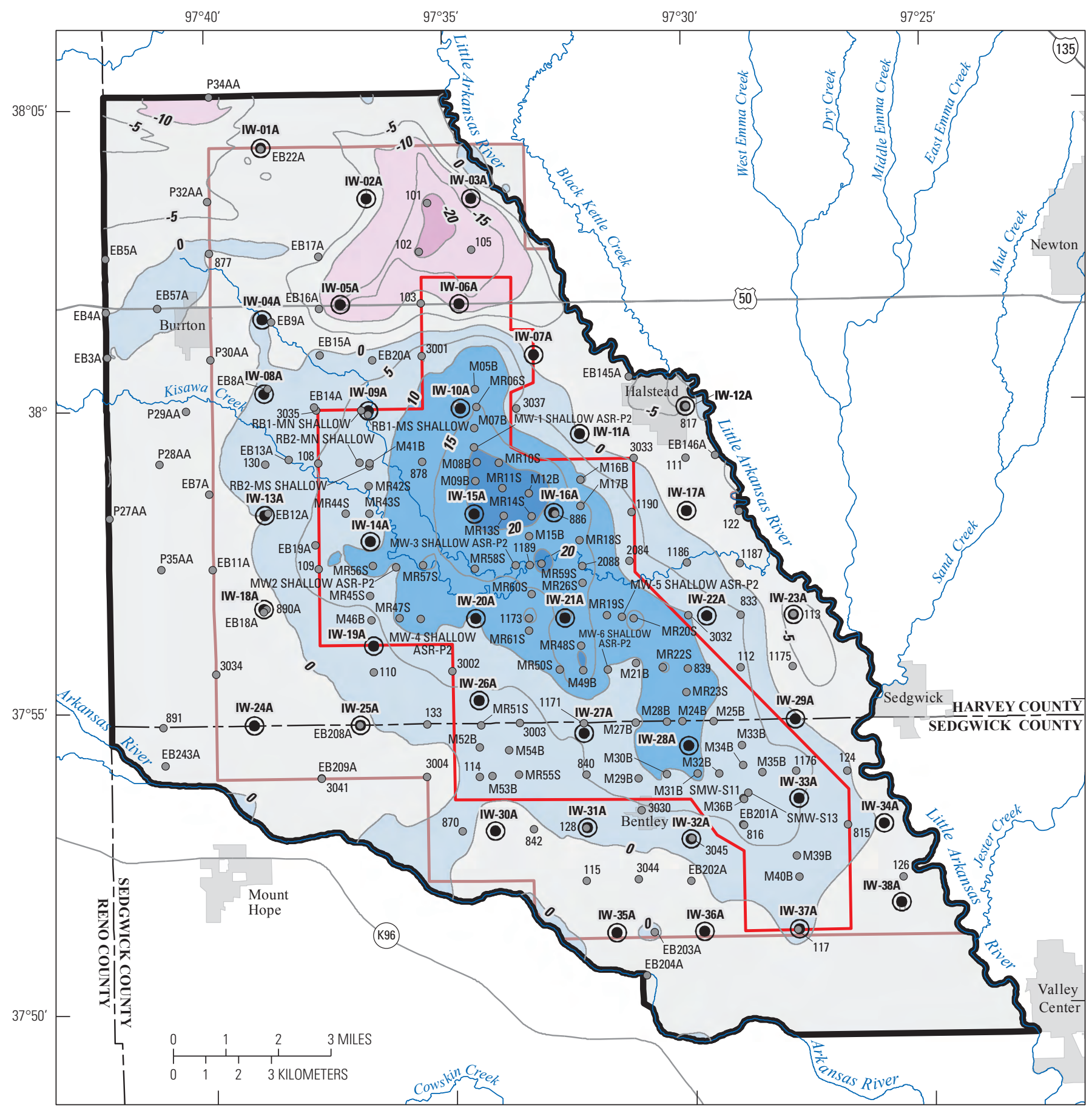

Base from U.S. Geological Survey digital data, 1:24,000, 2012 Universal Transverse Mercator projection, zone 14

Horizontal coordinate information is referenced to the North American Datum of 1983 (NAD 83)

EXPLANATION

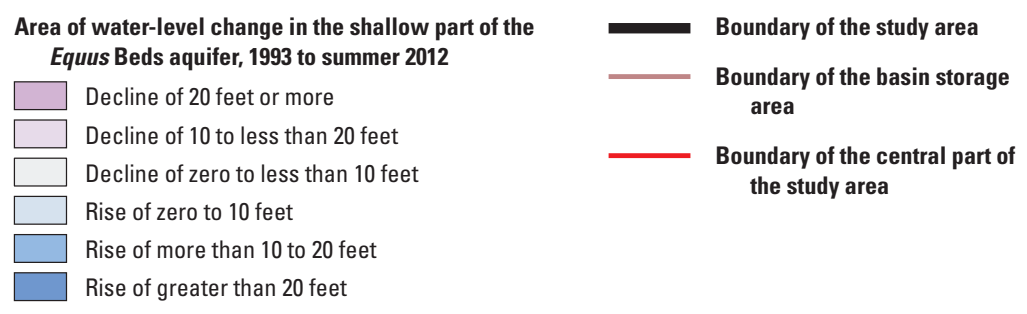

Modified from Hansen and others, 2014 


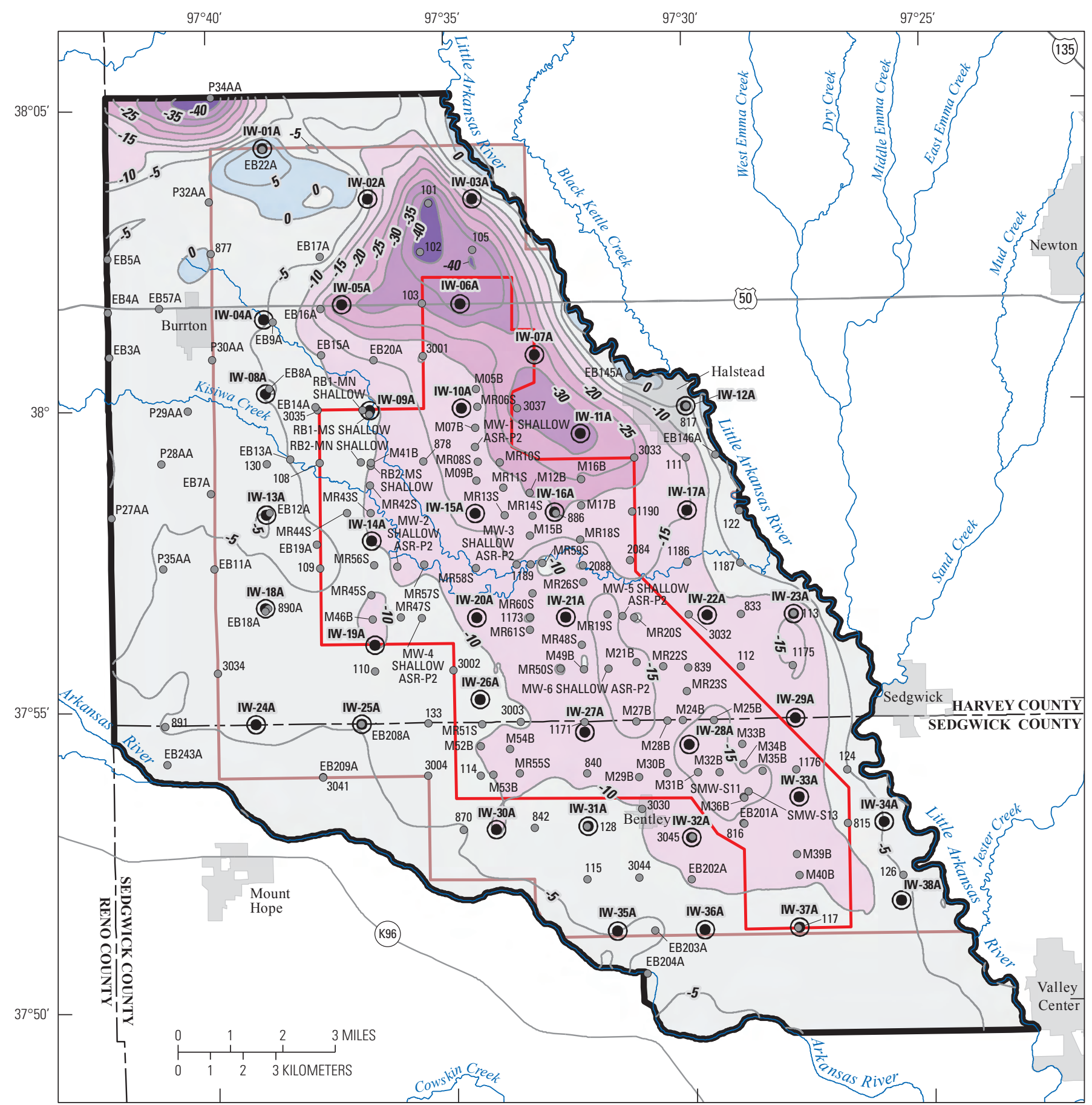

Base from U.S. Geological Survey digital data, 1:24,000, 2012 Universal Transverse Mercator projection, zone 14

Horizontal coordinate information is referenced to the North

American Datum of 1983 (NAD 83)

EXPLANATION

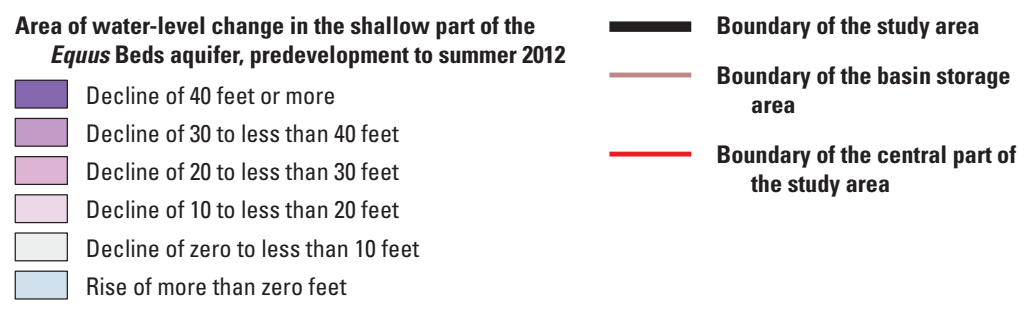
- -5 - Line of equal water-level change in the shallow part of the Equus Beds aquifer, predevelopment to summer 2012-Contour interval 5 feet
IW-36A
( I) Index monitoring well in the shallow part of the Equus Beds aquifer and identifier
EB204A Monitoring well in the shallow part of the Equus Beds aquifer and identifier

Figure 6. Water-level changes in the shallow part of the Equus Beds aquifer, predevelopment (1940) to summer 2012, south-central Kansas. 


\section{Purpose and Scope}

The purpose of this report is to describe Little Arkansas River and Equus Beds aquifer water quality during 1995 through 2012, including quantifying effects related to Phase I recharge activities of about 1 billion gal. Water quality before and concurrent with (2007 through 2012) implementation of large-scale (design capacity of 10 million gallons per day $[\mathrm{Mgal} / \mathrm{d}]$ ) recharge activities (Kansas Underground Injection Control Area Permit Class V Injection Well, Kansas Permit No. KS-05-079-001) at ASR Phase I sites are described. Water quality is described before the implementation of ASR Phase II, which began in 2013. This report includes waterquality data collected during 1995 through 2012, and these data are supplemented with available historical data. The study described herein is part of a long-term cooperative study (since 1940) between the city of Wichita and the USGS to describe the water quantity and quality conditions in the Equus Beds aquifer and Little Arkansas River, and the potential effects of artificial recharge on water resources in southcentral Kansas. The description of water-quality conditions in this report serves as a baseline to detect any subsequent water-quality changes in the Equus Beds aquifer and the Little Arkansas River during Phase II of the ASR project.

Water-quality samples were collected at 2 surface water monitoring sites on the Little Arkansas River, a network of 38 areal assessment index wells (IW) in shallow and deep parts of the aquifer, background wells, ASR prototype wells, and ASR Phase I and Phase II monitoring wells. A thorough description of these sites and site groupings can be found in the "Methods" section under the "Sampling Sites" subsection. Continuous chloride, arsenic, atrazine, and fecal indicator bacteria in the Little Arkansas River presented herein were computed using previously developed regression models (Christensen and others, 2000). Water-quality constituents of interest discussed in this report include those listed in the primary and secondary EPA Federal drinking-water criteria, as well as onsite measurements such as specific conductance and oxidation-reduction potential (ORP).

\section{Recent Water-Quality Studies}

Garinger and others (2011) examined water quality in and near an experimental passive gravity recharge well and trench system that was installed in 2009 as part of the Phase I recharge project at Recharge Basin 1 (RB1; fig. 1). After injecting about 576,000 gal of treated surface water from the Little Arkansas River, bacterial and viral indicators (total coliform, fecal coliform, Escherichia coli [E. coli], coliphage virus, and Clostridium perfringens) were documented to enter the RB-1 wells through the recharge system, and recharge was temporarily discontinued. The city of Wichita disconnected the trench collection system from the passive gravity recharge well in July 2009 and proceeded to withdraw 1,825,000 gal of water from the aquifer at RB-1 to remove the recharged water and avoid contamination of the aquifer. As part of the Phase II treatment facility, enhanced membrane filtration and advanced oxidative treatment processes are designed to better remove these indicator bacteria and viruses, but monitoring will provide critical information that can be used by water managers to verify the preservation of the aquifer water quality.

Kelly and others (2013) developed a model to describe groundwater changes and quantify artificial recharge in the Equus Beds aquifer. The model was used to determine groundwater flow in the Wichita well field area, which has several critical applications to the study area. One major application of the model is to quantify effects of changes in artificial and natural recharge, well pumping, and streamflow on groundwater. Additionally, the model can be used to simulate changes in water withdrawals, water levels caused by drought or pumping, and natural and artificial aquifer recharge. Lastly, the model can be used to simulate chloride movement throughout the aquifer, and evaluate different withdrawal and injection scenarios on chloride movement.

Klager and others (2014) added chloride simulations to the Kelly and others (2013) model to evaluate areas where model improvements were needed and to provide aquifer chloride movement scenarios. Under the existing pumping model scenario in the area between the Arkansas River and the southern boundary of the well field, the simulated 250-milligrams per liter $(\mathrm{mg} / \mathrm{L})$ chloride front moved north at an average rate of approximately 660 feet per year (ft/yr) in the shallow layer, $780 \mathrm{ft} / \mathrm{yr}$ in the middle layer, and $660 \mathrm{ft} / \mathrm{yr}$ in the deep layer. The simulated $250-\mathrm{mg} / \mathrm{L}$ chloride front moved toward the Wichita well field from the Burrton area at an approximate rate of $400 \mathrm{ft} / \mathrm{yr}$ in the shallow layer, $150 \mathrm{ft} / \mathrm{yr}$ in the middle layer, and $310 \mathrm{ft} / \mathrm{yr}$ in the deep layer (Klager and others, 2014).

Under the no pumping model scenario, chloride from the Arkansas River and the Burrton chloride plume still moved toward the Wichita well field (Klager and others, 2014). The 250-mg/L chloride front from the Arkansas River near the southern part of the well field moved north toward the well field at an approximate average rate of $500 \mathrm{ft} / \mathrm{yr}$ in the shallow layer (160 ft/yr slower than in a baseline scenario), $570 \mathrm{ft} / \mathrm{yr}$ in the middle layer (210 ft/yr slower than in a baseline scenario), and $510 \mathrm{ft} / \mathrm{yr}$ in the deep layer $(150 \mathrm{ft} / \mathrm{yr}$ slower than in a baseline scenario). The $250-\mathrm{mg} / \mathrm{L}$ chloride front in the Burrton plume moved southeast toward the well field at a rate of approximately $520 \mathrm{ft} / \mathrm{yr}$ in the shallow layer (120 ft/yr faster than in a baseline scenario), $70 \mathrm{ft} / \mathrm{yr}$ in the middle layer (80 ft/yr slower than a baseline scenario), and $190 \mathrm{ft} / \mathrm{yr}$ in the deep layer (120 ft/yr slower than in a baseline scenario; Klager and others, 2014).

The chloride transport model simulates movement of the Burrton chloride plume at less than 1 mile per decade in the Burrton area (Klager and others, 2014). Results of modeling scenarios indicate that the Burrton chloride plume will continue moving toward the well field regardless of pumping in the area. Eastward movement of the Burrton chloride plume was slowed by the additional artificial recharge at Phase I sites coupled with decreased pumping by the city of Wichita. 
Decreasing pumping along the Arkansas River or increasing water levels will deter chloride movement and may prevent further encroachment into the southern part of the well field area.

\section{Methods}

Streamflow, groundwater-level, and water-quality data were collected from the Little Arkansas River and from the Equus Beds aquifer from 1995 to 2012. A full listing of datacollection sites used to describe water quality in the Little Arkansas River and in the Equus Beds aquifer for this report can be accessed in table 1-1 (appendix 1 at the back of this report).

\section{Sampling Sites}

Water quality in the Equus Beds aquifer was defined using samples collected at 38 areal assessment index well sites (each site with one deep and one shallow well), 7 diversion well sites, 13 background wells, 9 Artificial Storage and Recovery prototype wells, and 66 Artificial Storage and Recovery Phase I and Phase II monitoring wells. Locations of the surface water sites, stream diversion sites, and monitoring wells are shown in figures $7 A$ and $7 B$. GMD2 provided data for the wells they monitored (wells with $\mathrm{EB}$ and $\mathrm{P}$ prefixes on figs. $7 A$ and $7 B$; Tim Boese, Manager, Equus Beds Groundwater Management District Number 2, written commun., 2012). Surface water samples were collected at USGS streamflowgaging stations on the Little Arkansas River at Highway 50 near Halstead, Kans. (07143672), and near Sedgwick, Kans. (07144100). These two stations also are continuous real-time water-quality monitoring sites.

Monitoring wells discussed in this report were divided into two groups by depth (shallow and deep) to describe differences in water quality of the Equus Beds aquifer within the study area. Shallow wells (fig. $7 A$ ) were at depths below land surface equal to or less than $80 \mathrm{ft}$, and deep wells (fig. $7 B$ ) were at depths greater than $80 \mathrm{ft}$ deep. All IWs and ASR Phase I monitoring wells were constructed of polyvinyl chloride (PVC) pipe and the screened interval is typically in the lowermost 10 to $20 \mathrm{ft}$ of the casing. All ASR Phase I recharge locations are accompanied with several shallow and deep monitoring wells (fig. $7 A$ and $7 B$ ). Additionally, as part of the demonstration project, monitoring wells were installed near the Sedgwick and Halstead recharge sites and have been described in more detail by Ziegler and others (1999), Schmidt and others (2007), and Ziegler and others (2010).

Ziegler and others (1999) described the background wells, which include 13 shallow monitoring wells along the Little Arkansas River. ASR prototype sites include 12 deep monitoring wells installed by the city of Wichita in 2002 and 2004 near potential locations for large-scale withdrawal and artificial recharge. Three of the ASR prototype wells
(RRW-1-RRW-3) became Phase I recharge sites; therefore, these sites will be referred to as ASR Phase I recharge sites hereafter (figs. $7 A$ and $7 B$ ). ASR Phase II monitoring sites (figs. $7 A$ and $7 B$ ) were established in 2010 to monitor future recharge operations during Phase II of the ASR project (operational in 2013). Lastly, 38 areal assessment IW sites were established by the city of Wichita throughout the study area in 2001; each IW site included a shallow and a deep monitoring well (figs. $7 A$ and $7 B$ ). Statistical summaries of shallow and deep groundwater chemistry presented herein are based on water samples collected in the IW network, whereas distribution maps of individual constituents include data from all groundwater sites (IWs, diversion well sites, background wells, ASR prototype wells, and ASR Phase I and Phase II monitoring wells) in the study area.

\section{Water-Sample Collection}

Discrete and continuous water-quality data are used in this report to describe water quality in the Little Arkansas River and the Equus Beds aquifer. Methods for sample collection are described in detail in Ziegler and Combs (1997), Ziegler and others (1999), and Ziegler and others (2010). Discrete water-quality samples were collected from two surface water monitoring sites on the Little Arkansas River (07143672 and 07144100), recharge demonstration sites, ASR Phase I and Phase II monitoring sites, and from IW and other wells within the study area (fig. $7 A$ and $7 B$ ). Continuous water-quality data also were collected at the two Little Arkansas River sites.

\section{Discrete Surface and Groundwater-Quality Samples}

Sampling frequency varied depending on site type. Samples were collected at least six times per year for a range of hydrologic conditions from the two surface water monitoring sites on the Little Arkansas River during 1995 through 2012. Water samples from IWs were collected at least six times during 2001 through 2002 and annually thereafter. Decreased sampling frequency of IWs resulted from generally small variability in concentrations of water-quality constituents of interest. ASR prototype wells were sampled annually during 2002 through 2012, whereas monitoring wells associated with ASR Phase I recharge sites were sampled at least annually from 2006 to 2012 and monitoring wells associated with future ASR Phase II sites were sampled at least annually during 2010-2012. The current location of ASR Phase II sites MW-7 and MW-8 (fig. 7A and 7B) is the former location of the demonstration project Sedgwick recharge sites. Analyses of these samples were used for determining effects on water quality in the Equus Beds aquifer during the demonstration phase of the recharge project.

Water samples collected during 1995 through 2012 were analyzed for targeted physical properties, major ions, nutrients, dissolved trace elements, organic compounds, and bacterial 


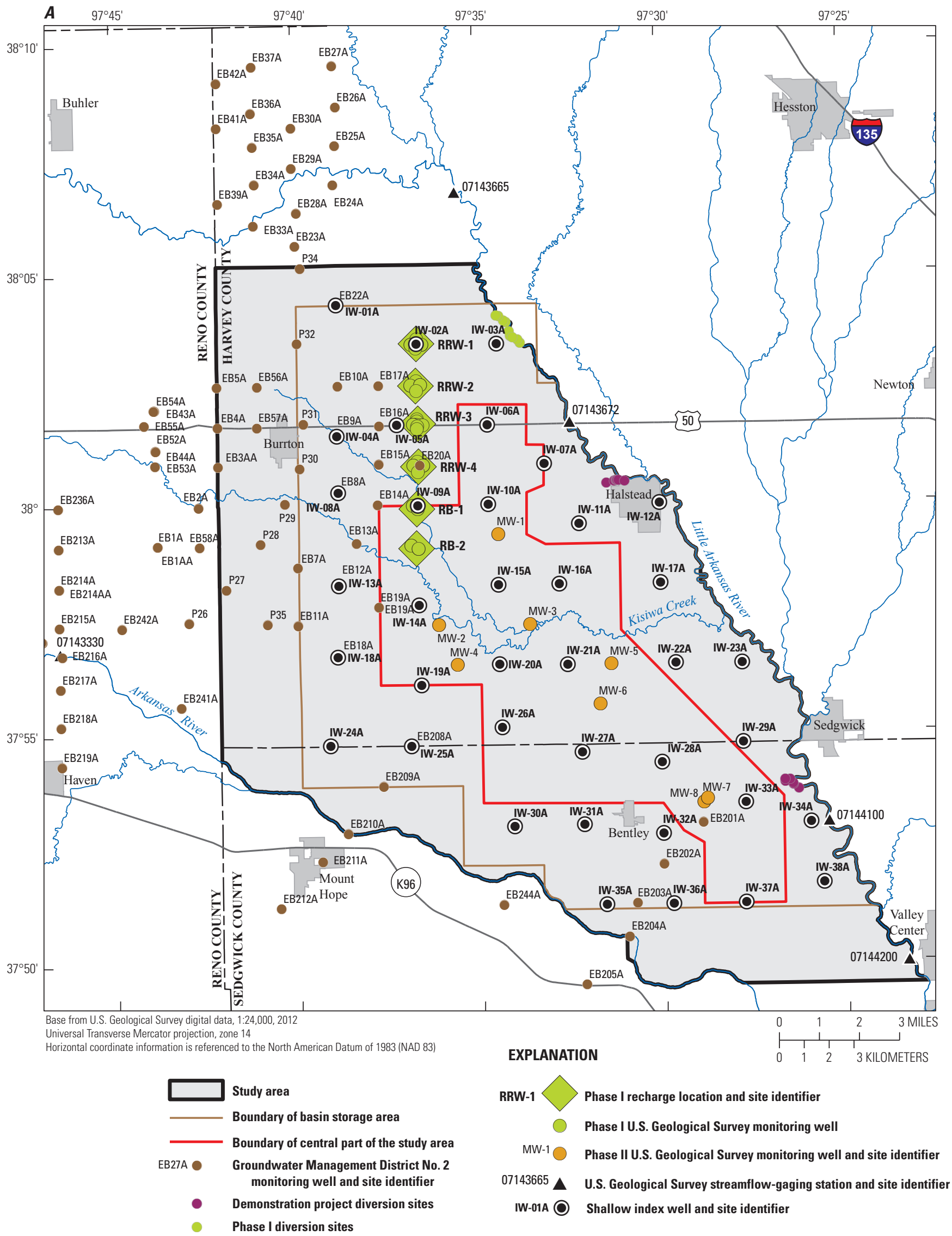

Figure 7. Location of $A$, surface water and shallow groundwater monitoring sites; and $B$, surface water and deep groundwater monitoring sites in and near the study area, south-central Kansas. 


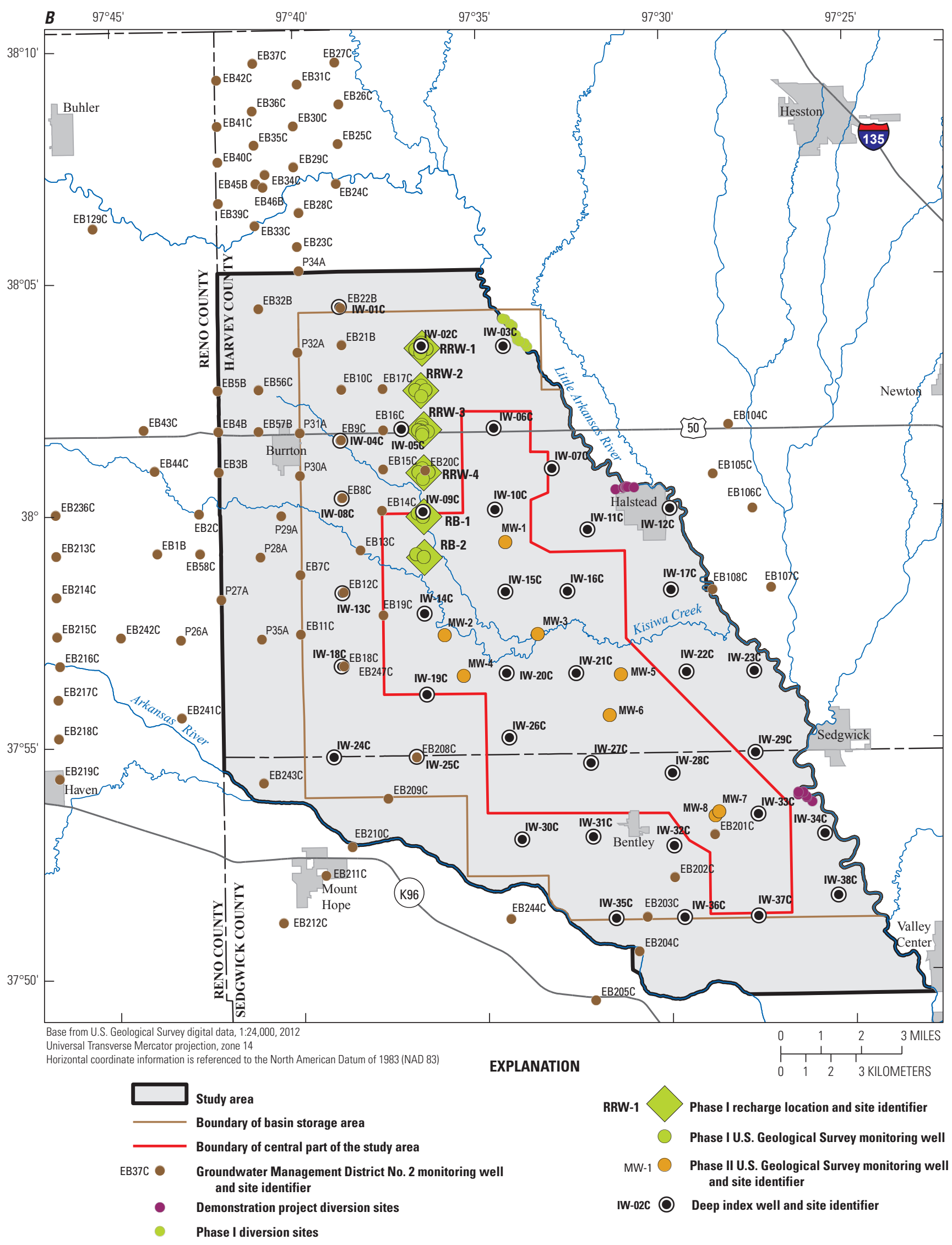

Figure 7. Location of $A$, surface water and shallow groundwater monitoring sites; and $B$, surface water and deep groundwater monitoring sites in and near the study area, south-central Kansas.-Continued 
and viral indicators. A summary detection table of constituents of concern in groundwater samples at all sites during 1995-2012 is presented in table 2. Dissolved concentrations of constituents were defined operationally by filtering samples through a 0.45 -micrometer $(\mu \mathrm{m})$ pore-size filter. Selected samples were analyzed for additional constituents, including inorganic compounds, radionuclides, organic compounds, and bacterial and viral indicators. In addition to constituents of concern, radionuclides and other organic compounds including pesticides and their metabolites, volatile organic compounds (VOCs), acid and base/neutral compounds, and pharmaceutical and personal care compound detection tables for surface water and groundwater samples are available online (http:// ks.water.usgs.gov/equus-water-quality, June 2014).

Physical properties and concentrations of dissolved solids, major ions, nutrients, dissolved trace elements, radionuclides, organic compounds, and coliform bacteria analysis methods were described by Ziegler and Combs (1997). Arsenic speciation data were collected and analyzed using methods described in Garbarino and others (2002). Fecal and viral indicator bacteria analyses were done using methods described by Bisson and Cabelli (1979, 1980), Britton and Greeson (1987), Armon and Payment (1988), Payment and Franco (1993), and the U.S. Environmental Protection Agency (1996, 2000, 2001a, 2006b, 2006c, 2006d, and 2006e). Samples were analyzed by the city of Wichita laboratory (Wichita, Kans.), the USGS National Water Quality Laboratory (Denver, Colorado), and the USGS Organic Geochemistry Research Laboratory (Lawrence, Kans.). Further information regarding data-collection methods, preservation, sample holding times, analytical methods, and reporting levels can be found in Ziegler and Combs (1997).

In addition to summary data presented in this report, individual sample analyses are available online at http:// waterdata.usgs.gov/ks/nwis/qw. Statistical summaries of these water-quality data are available at http://ks.water.usgs.gov/ equus-water-quality. Average and median concentrations of water-quality constituents from discrete samples presented in statistical summary tables in this report were calculated using the summary statistics program that is part of the USGS National Water Information System (NWIS). This program uses statistical methods described in Helsel (2005). More information on the NWIS summary statistics program and censored observations can be found in Ziegler and others (2010). Additionally, for time-period comparisons of iron data in this report all observations less than $100 \mu \mathrm{g} / \mathrm{L}$ were censored to $100 \mu \mathrm{g} / \mathrm{L}$ because the minimum detection limit for iron analysis by the city of Wichita laboratory changed from $5 \mu \mathrm{g} / \mathrm{L}$ to $100 \mu \mathrm{g} / \mathrm{L}$.

\section{Continuous Surface Water-Quality Monitoring}

Streamflow was measured using standard USGS methods (Sauer and Turnipseed, 2010; Turnipseed and Sauer, 2010) beginning in 1988 at the streamflow-gaging stations on the Little Arkansas River at Highway 50 near Halstead, Kans., and near Sedgwick, Kans. Each site was also equipped with a Yellow Springs Incorporated 6600 Extended Deployment System water-quality monitor to continuously measure specific conductance, $\mathrm{pH}$, water temperature, dissolved oxygen, and turbidity. The sensors were calibrated and maintained according to methods presented in Wilde and Radke (1998), and Wagner and others (2006). Measurements from continuous monitoring sensors were checked against a calibrated field meter during site visits. Continuous monitoring sensors were cleaned of any mud or debris and calibrated as needed. Continuous monitoring sensors collected daily data at 15 to 60 minute time intervals, and these data are available at http:// nrtwq.usgs.gov/ks.

\section{Quality Assurance and Quality Control}

Quality assurance and quality control (QA/QC) samples routinely were collected to identify, quantify, and document bias and variability in data that resulted from collection, processing, handling, and analyzing samples (U.S. Geological Survey, 2006). QA/QC samples included replicate, blank, and standard reference samples. More than 500 QA/QC samples were collected from surface water and groundwater sites during 1995 through 2012. Ziegler and others (2010) evaluated QA/QC samples collected during 1995 through 2004. Samples collected during 2005 through 2012 were summarized for this report.

Replicate samples are collected simultaneously or close in time with the associated environmental sample using identical procedures (U.S. Geological Survey, 2006). Replicate samples are compared with their respective environmental sample using relative percentage difference (RPD), calculated as the difference between the replicate and the environmental sample concentrations divided by the average of the two values multiplied by 100 . During 2005 through 2012, roughly 240 replicate water-quality samples were collected from surface water and groundwater sites. The median RPDs for all sites combined did not exceed 10 percent for any analyzed constituent (fig. 1-1) indicating that sampling and analysis methods were consistent, and did not introduce large bias or variability into the dataset. RPDs for individual sample pairs that exceeded 10 percent generally occurred at concentrations near reporting levels. The primary sources of larger RPDs recorded during 1999 through 2004 (fig. 1-1) are discussed in Ziegler and others (2010).

Blank samples were collected to measure the magnitude of contaminant concentration that might have been introduced into samples as a result of sampling, processing, and analytical procedures (U.S. Geological Survey, 2006). Blank samples are composed of deionized water, inorganic blank water, or pesticide-grade blank water depending on analyses. During 2005 through 2012, roughly 100 blank samples associated with surface water and groundwater sites were collected. The largest number of detections was recorded in filtered and unfiltered organic carbon samples (fig. 1-2). Nearly all carbon 


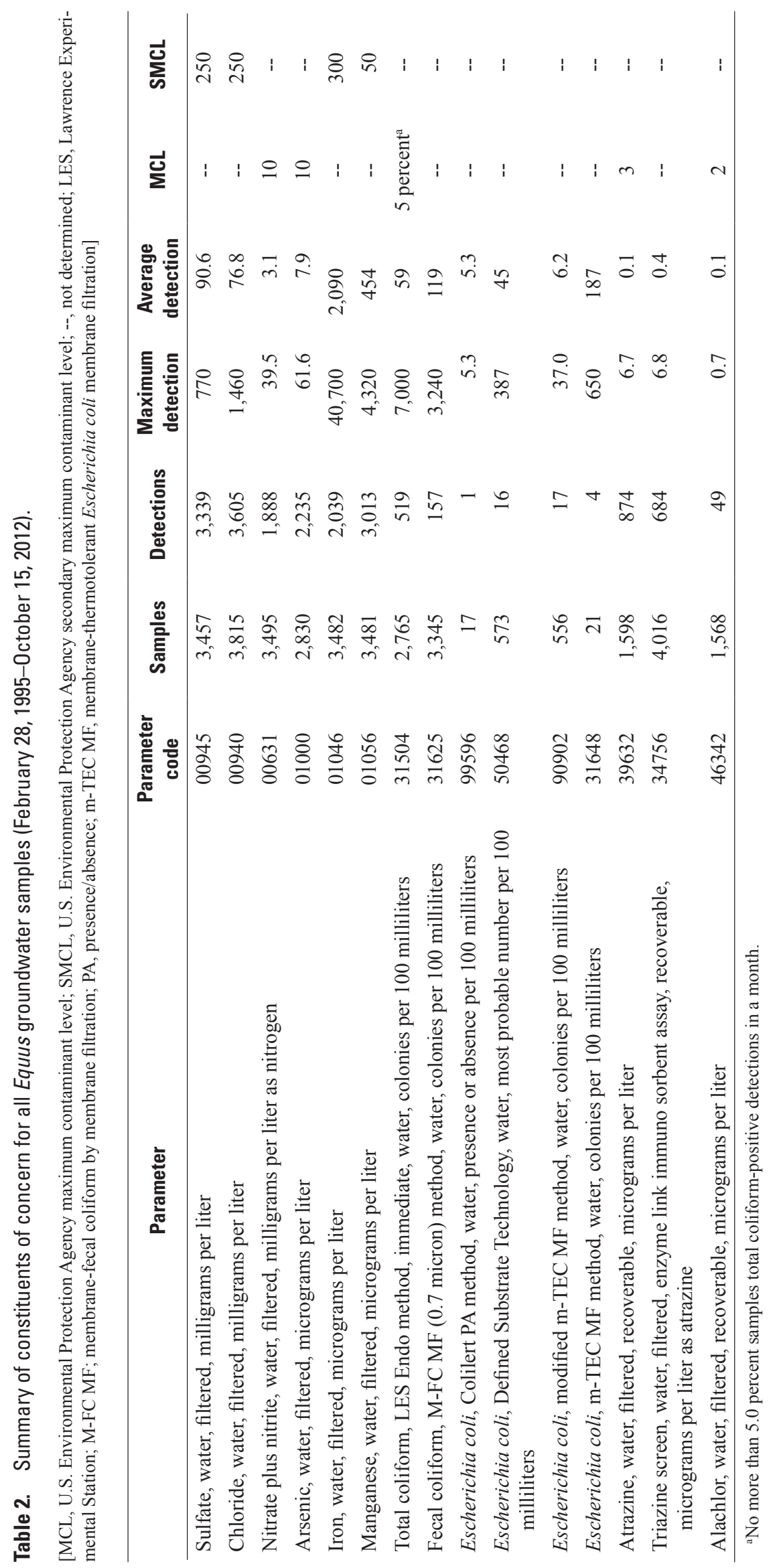


detections were near the detection limit. A few carbon detections were traced to potentially contaminated blank water used for the samples. Detections for the remaining constituents also were near detection limits.

Standard reference samples were analyzed by the Wichita Municipal Water and Wastewater laboratory at least annually and usually twice annually. Samples were submitted to the USGS Branch of Quality Systems for laboratory performance evaluation. Evaluation of the Wichita laboratory indicated that reported values usually were within 10 percent of the most probable value during 2005-2012. Median percent differences for all analytes were less than 10 percent. Results indicated that the laboratory data generally were consistent and not biased.

\section{Regression Analysis}

Statistical methods presented in Helsel and Hirsch (1992, 2002) were used to develop regression models between waterquality constituent concentrations in surface water samples and physical properties such as specific conductance, $\mathrm{pH}$, water temperature, and turbidity (Christensen and others 2000, 2003; Rasmussen and Ziegler, 2003). These models were used to provide real-time computations of concentrations and loads for selected major ions, nutrients, arsenic, atrazine, and fecal indicator bacteria in the Little Arkansas River. Real-time computed concentrations contribute to a better understanding of the distribution and seasonal variations of these constituents of interest in the Little Arkansas River; however, model uncertainly results in limitations of computed concentration data and should not replace discrete sampling. Information regarding computed concentrations, duration curves, and model uncertainty is available online at http://nrtwq.usgs.gov/ks/.

Ziegler and others (2010) used previously developed ordinary least-square regression models (Helsel and Hirsch, 2002) to estimate concentrations of water-quality constituents in groundwater. These models help to explain the distribution of these constituents in the study area. They also provide the ability to compute concentrations of constituents in groundwater for future use and in parts of the Equus Beds aquifer without complete chemical analyses using basic constituent data from onsite sensor measurements. The following three medium to strong relations (coefficient of determination $\left[\mathrm{R}^{2}\right]$ between 0.5 and 1.0) for groundwater IWs were developed through statistical regression: (1) specific conductance and sulfate concentration, (2) specific conductance and chloride concentration, and (3) ORP and arsenic concentration (Ziegler and others, 2010).

\section{Effective Porosity}

Effective porosity is a measure of the interconnected pore volume within a rock layer that contributes to fluid flow (Lohman, 1972) and is expressed as a percentage of the total volume. Effective porosity for the entire thickness of the aquifer was computed by Ziegler and others (2010) and is presented in figure 8. Ziegler and others (2010) point out that changes related to the water quality of the Equus Beds aquifer may occur more rapidly in areas with larger effective porosity. Therefore, areas of particular interest because of large estimated effective porosities (greater than 15 percent) are along the western and southern parts of the study area, near the Little Arkansas River, and in the central part of the study area (fig. 8; Ziegler and others, 2010).

\section{Water-Quality Constituents of Concern}

Of all the constituents analyzed, only those that frequently exceeded EPA Federal drinking- water-quality criteria, those that are of potential concern for artificial recharge operations, and those that may change as a result of artificial recharge are discussed in this report. These constituents include dissolved ions (sulfate and chloride), nutrients, trace elements (arsenic, iron, and manganese), triazine herbicides (atrazine), alachlor, and bacterial (fecal coliform, E. coli, and total coliform) and viral (Clostridium perfringens and E. coli coliphage) indicators. Average concentrations for specific constituent analysis are frequently reported; however, median concentrations of constituents are highlighted in instances when concentrations are highly variable and not normally distributed (for example, surface water nutrients, pesticides, and bacteria). Statistical summaries of these constituents are presented for the two surface water monitoring sites on the Little Arkansas River (table 3), shallow IWs, deep IWs, and sites associated with ASR Phase I recharge (table 4). Aquifer water-quality changes associated with the timing of Phase I recharge are presented in table 5. Detailed summaries of all water-quality monitoring results are presented on the Equus Beds Water Quality Web site at http://ks.water.usgs.gov/ equus-water-quality.

\section{Water Quality of the Equus Beds Aquifer and Little Arkansas River, 1995-2012}

To develop a baseline for the artificial recharge project, data collection began in 1995 and is currently (2015) ongoing. Data gathered from 1995 to 2005 were summarized by Ziegler and others (2010), whereas additional data gathered from 2006 to 2012 is appended to the previously collected data in Ziegler and others (2010) and is summarized in this report. Water-quality data in this report extend from 1995 to 2012 and in some instances were divided into two periods to examine multi-year temporal changes or trends in the IW network, which was established by the city of Wichita in 2001. This is useful because it underscores potential water-quality changes associated with ASR Phase I and establishes a baseline for 


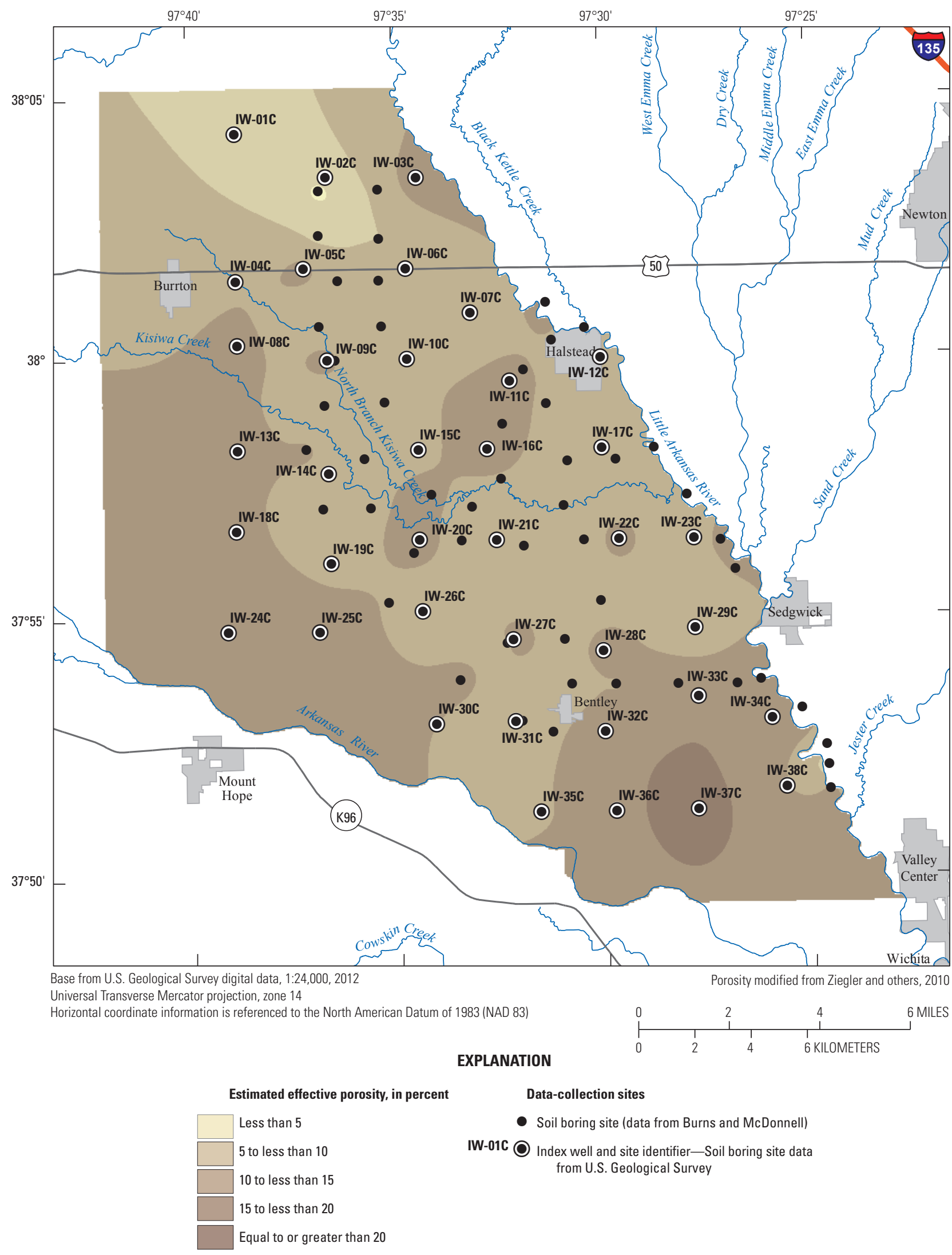

Figure 8. Estimated effective porosity in the study area, south-central Kansas. 


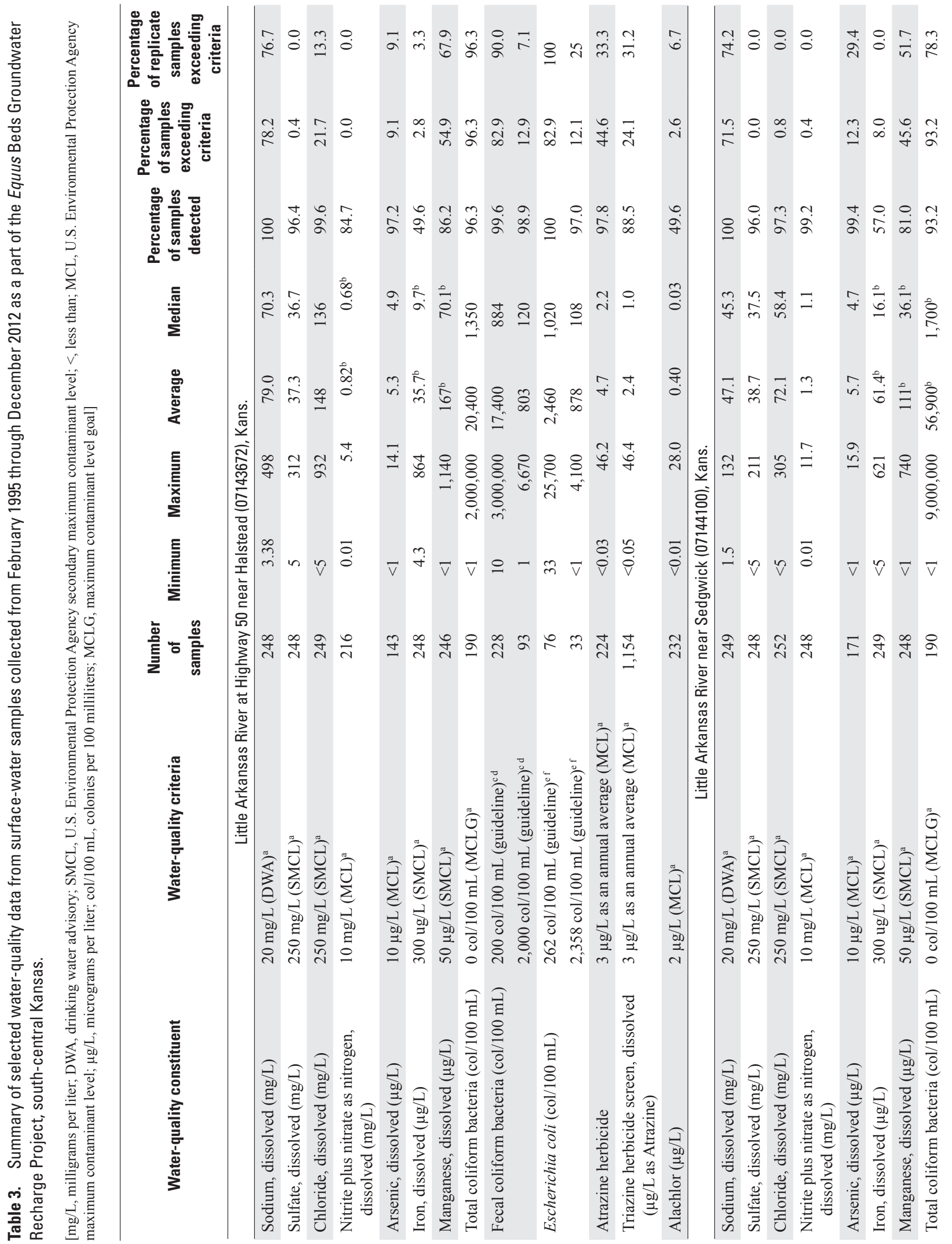




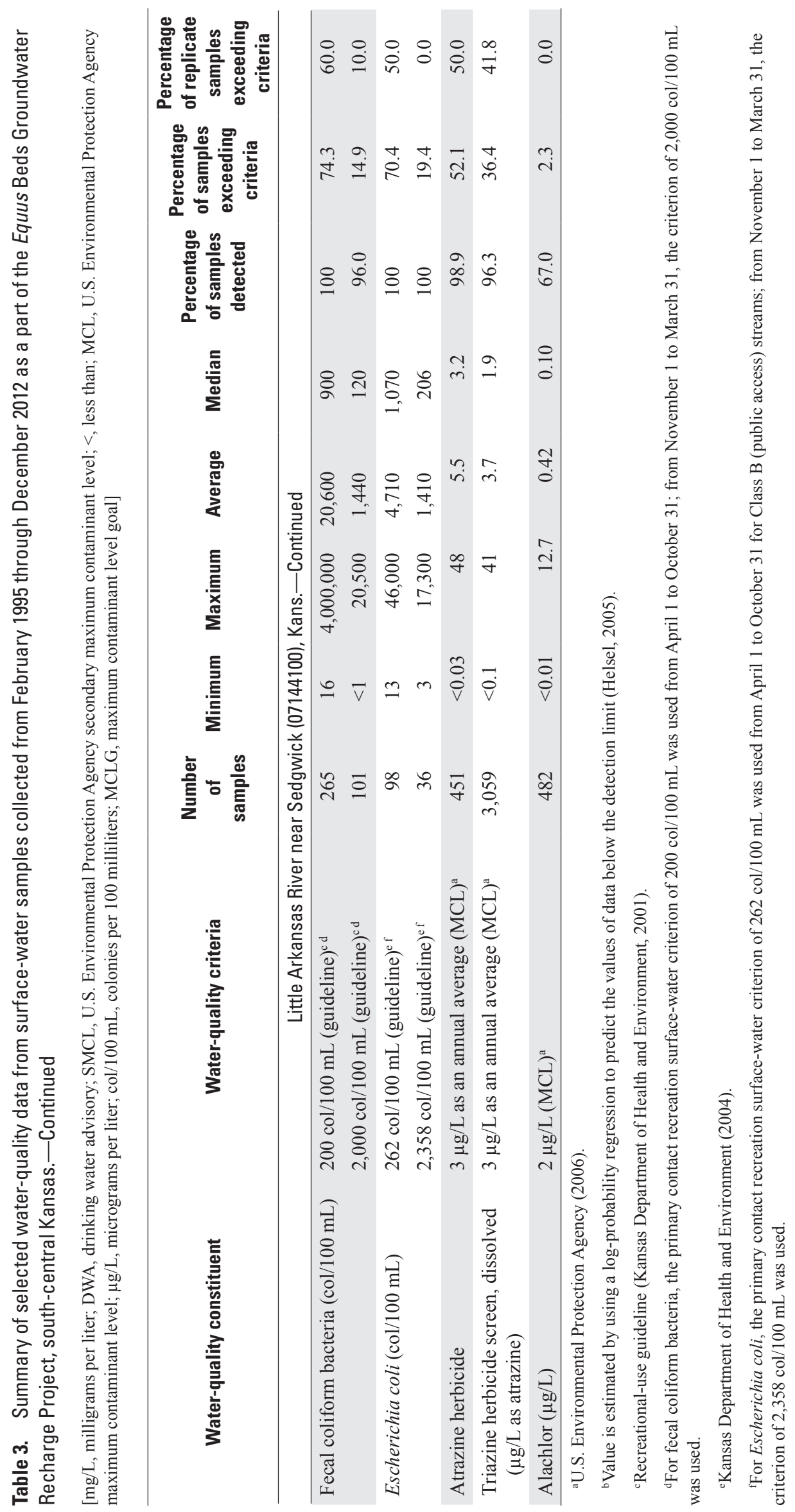




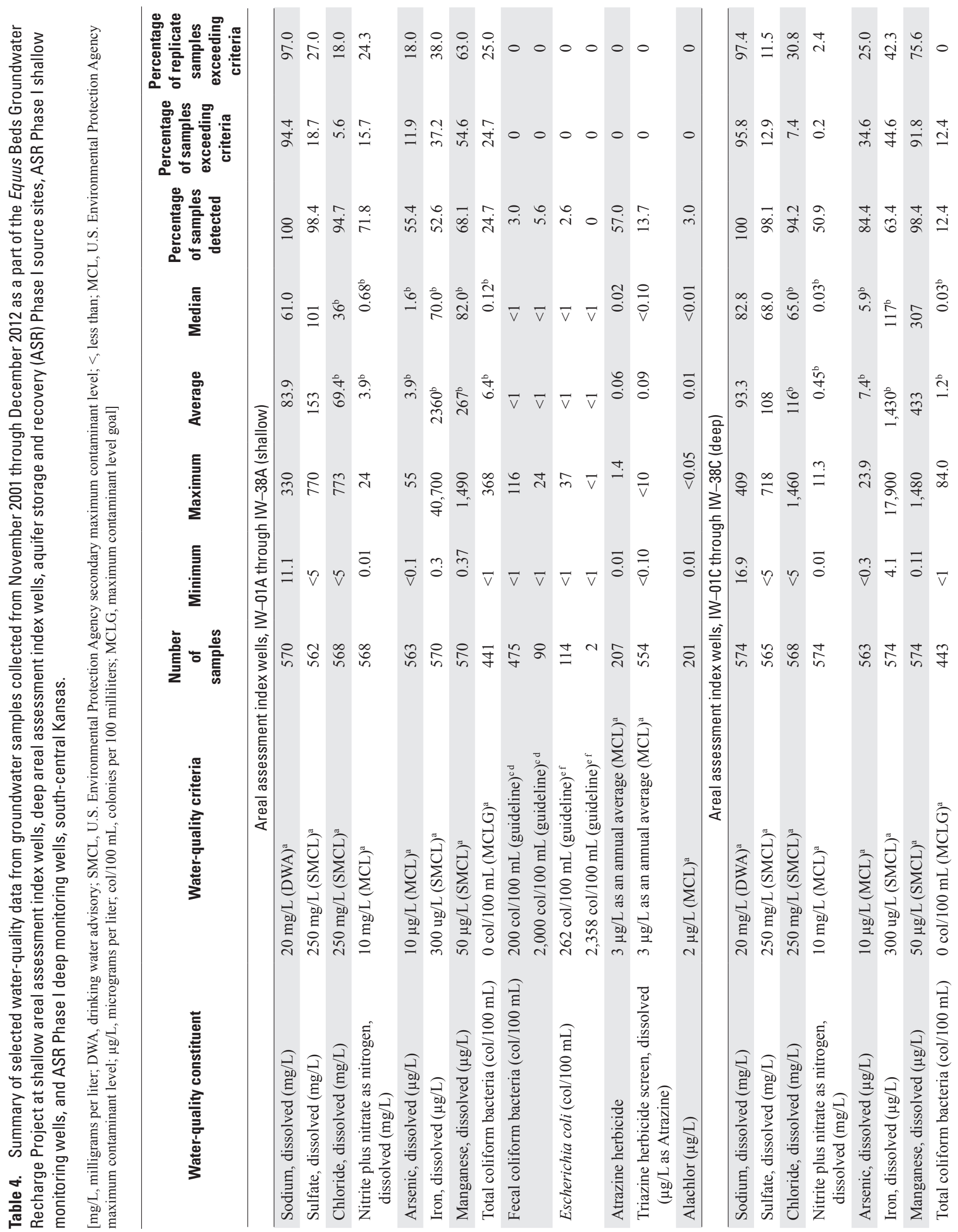


22 Water Quality of the Little Arkansas River and Equus Beds Aquifer Before and Concurrent with Large-Scale Artificial Recharge

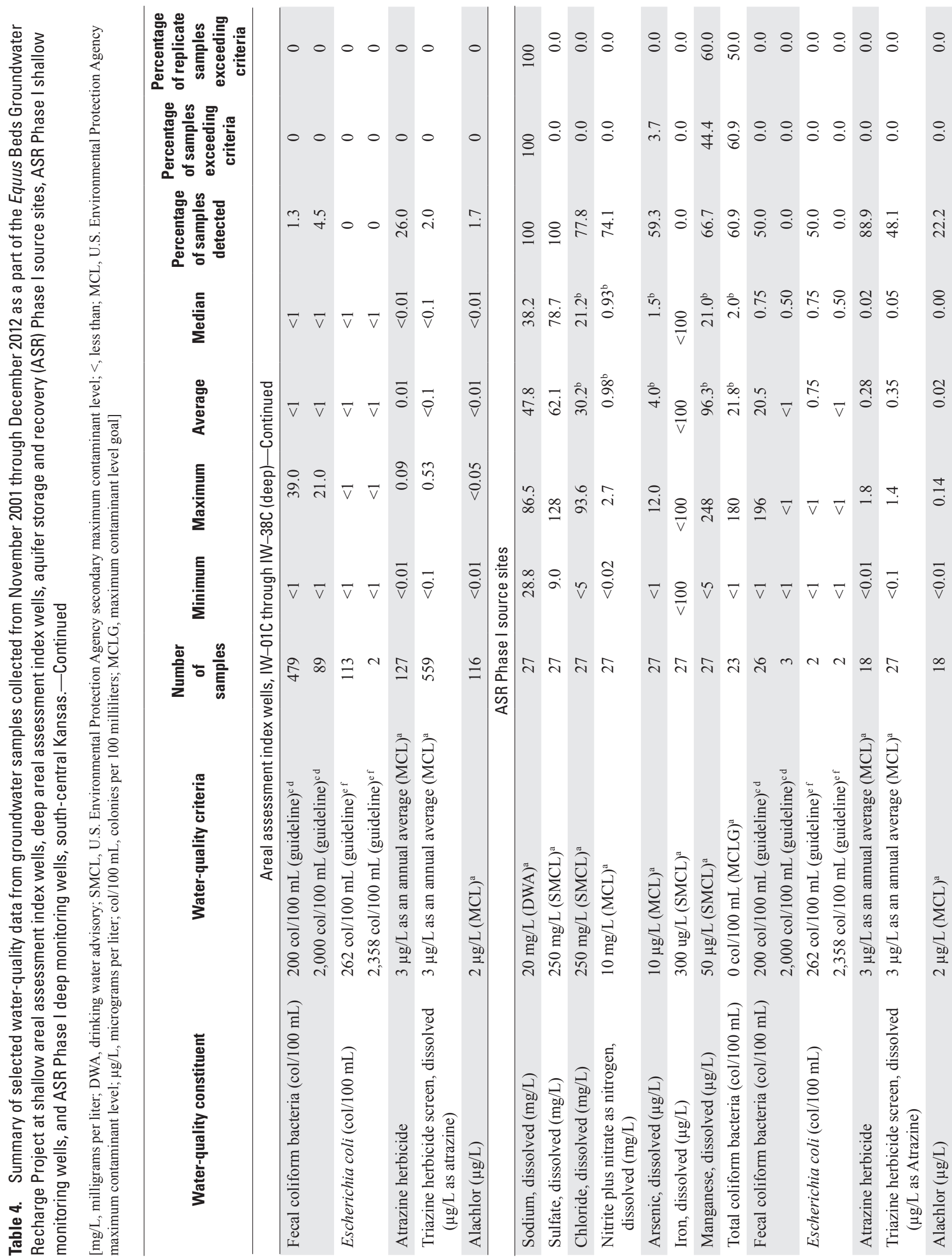




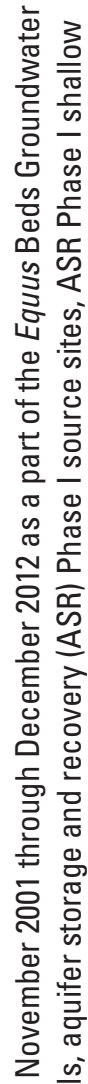

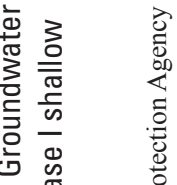

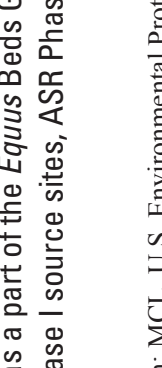

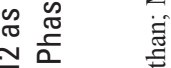

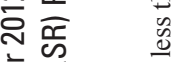

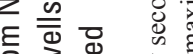

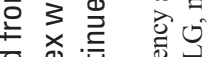

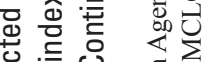

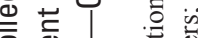

¿

s

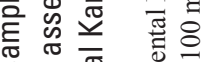

原

远需

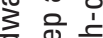

要 䓂

음

들

일

要

要

索奇

政

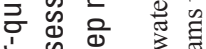

这兽

उ

要

उँ

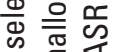

此的

究苋

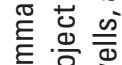

羊 임

은.

过

을 응

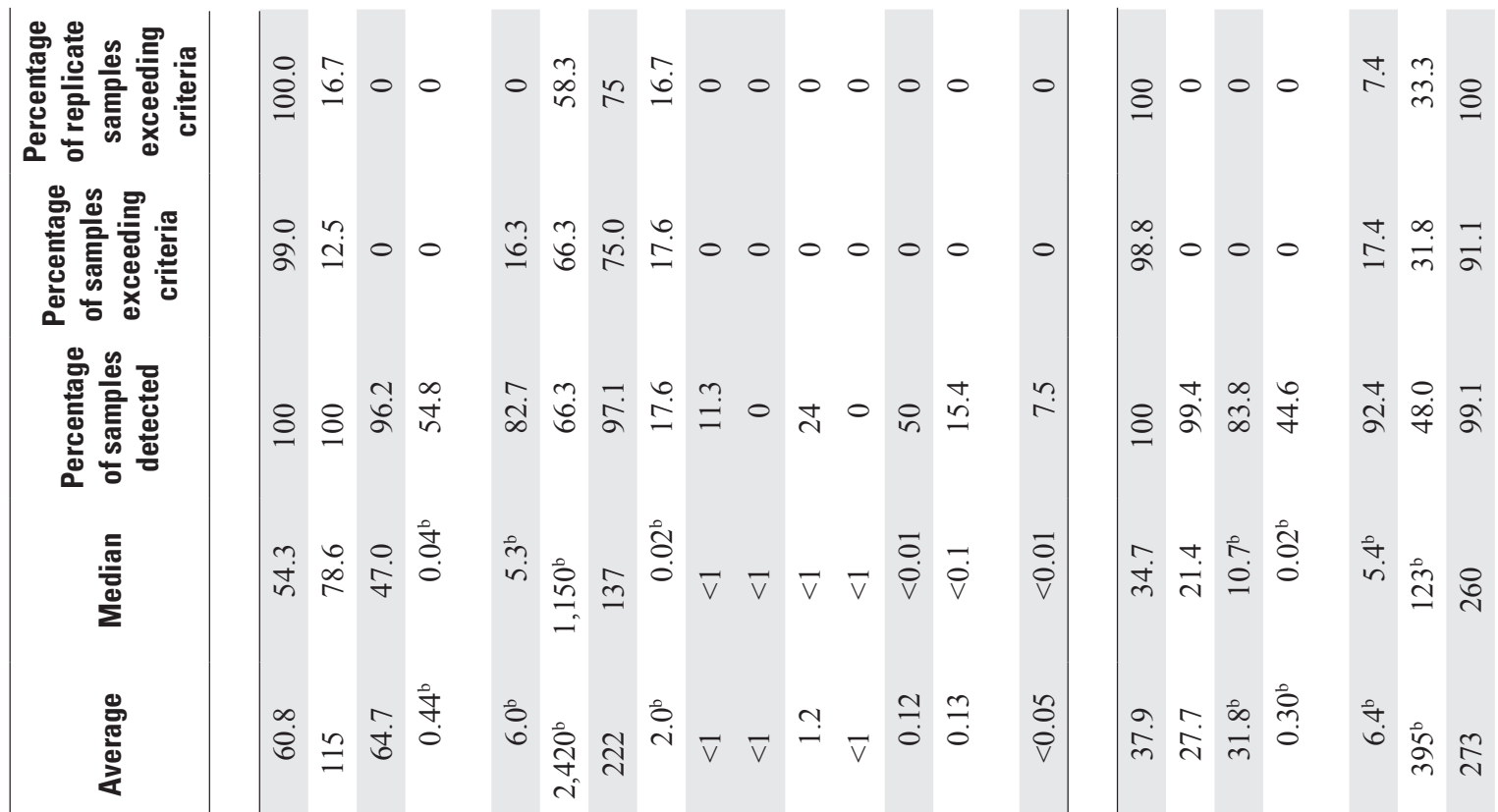

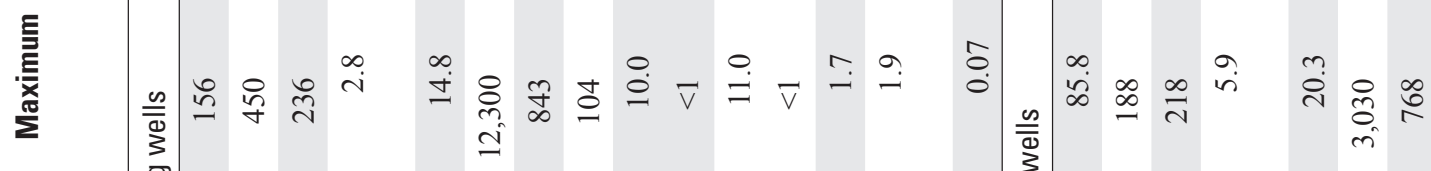

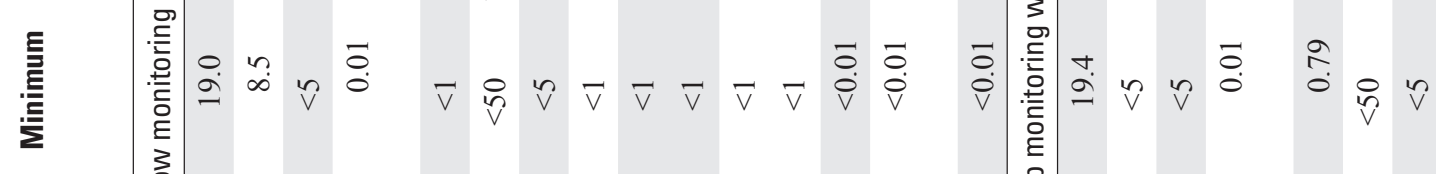

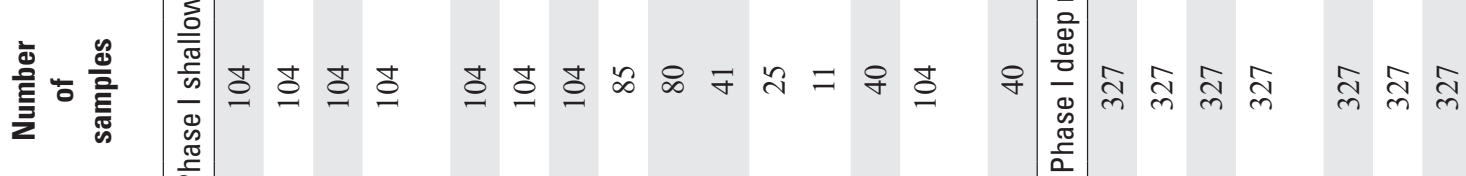
 孚

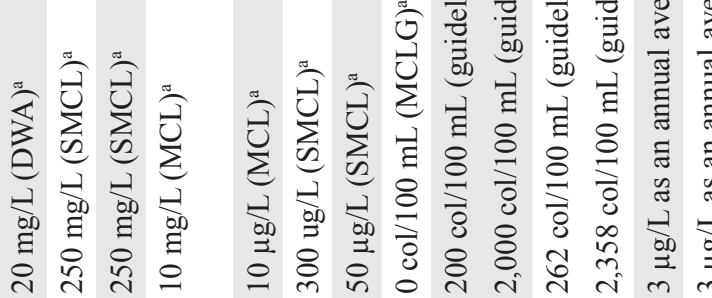

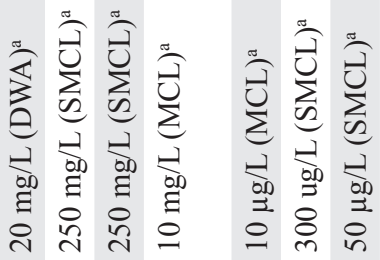
䓂

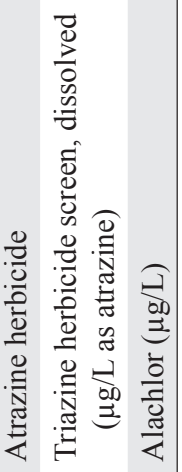




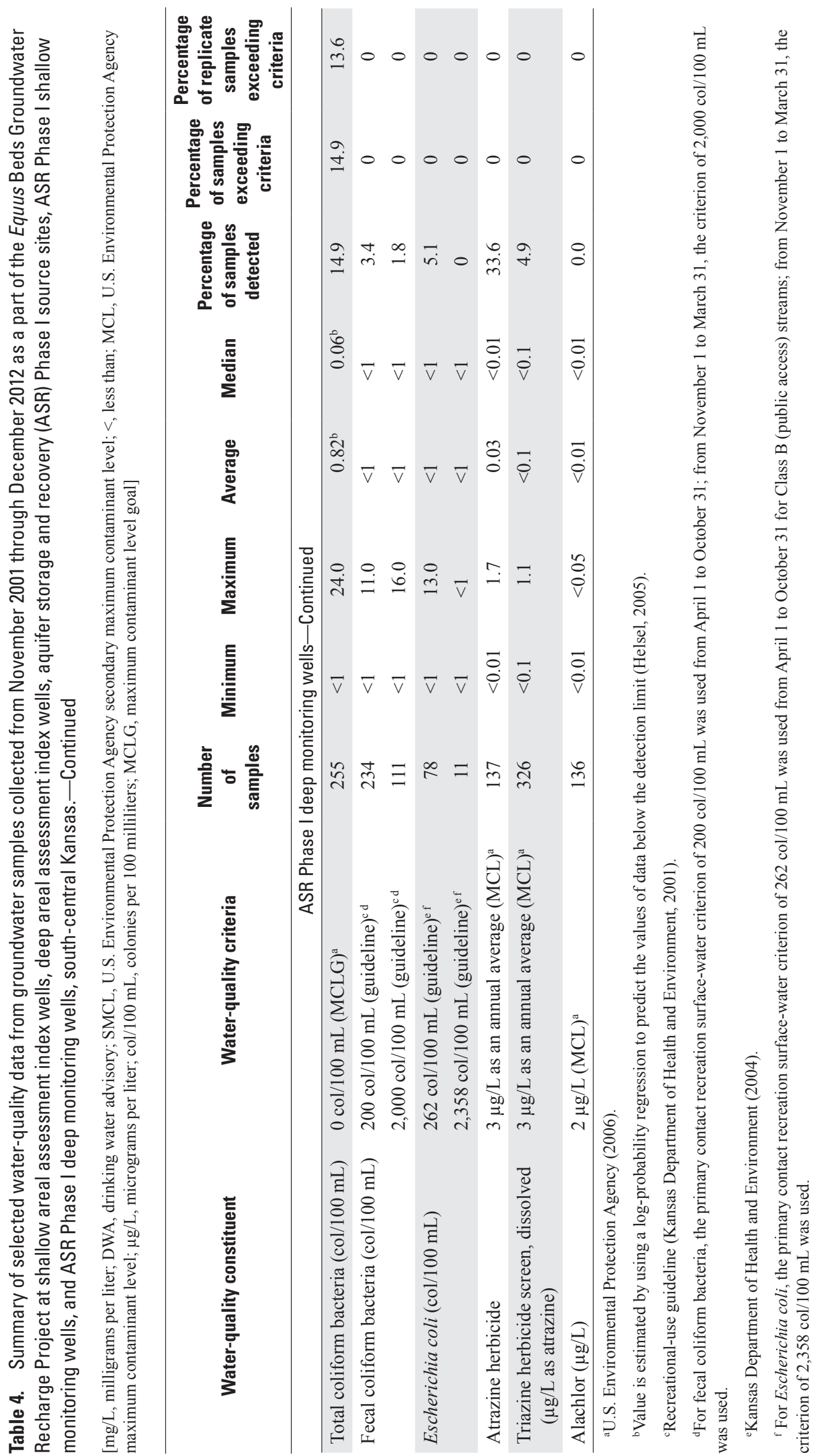




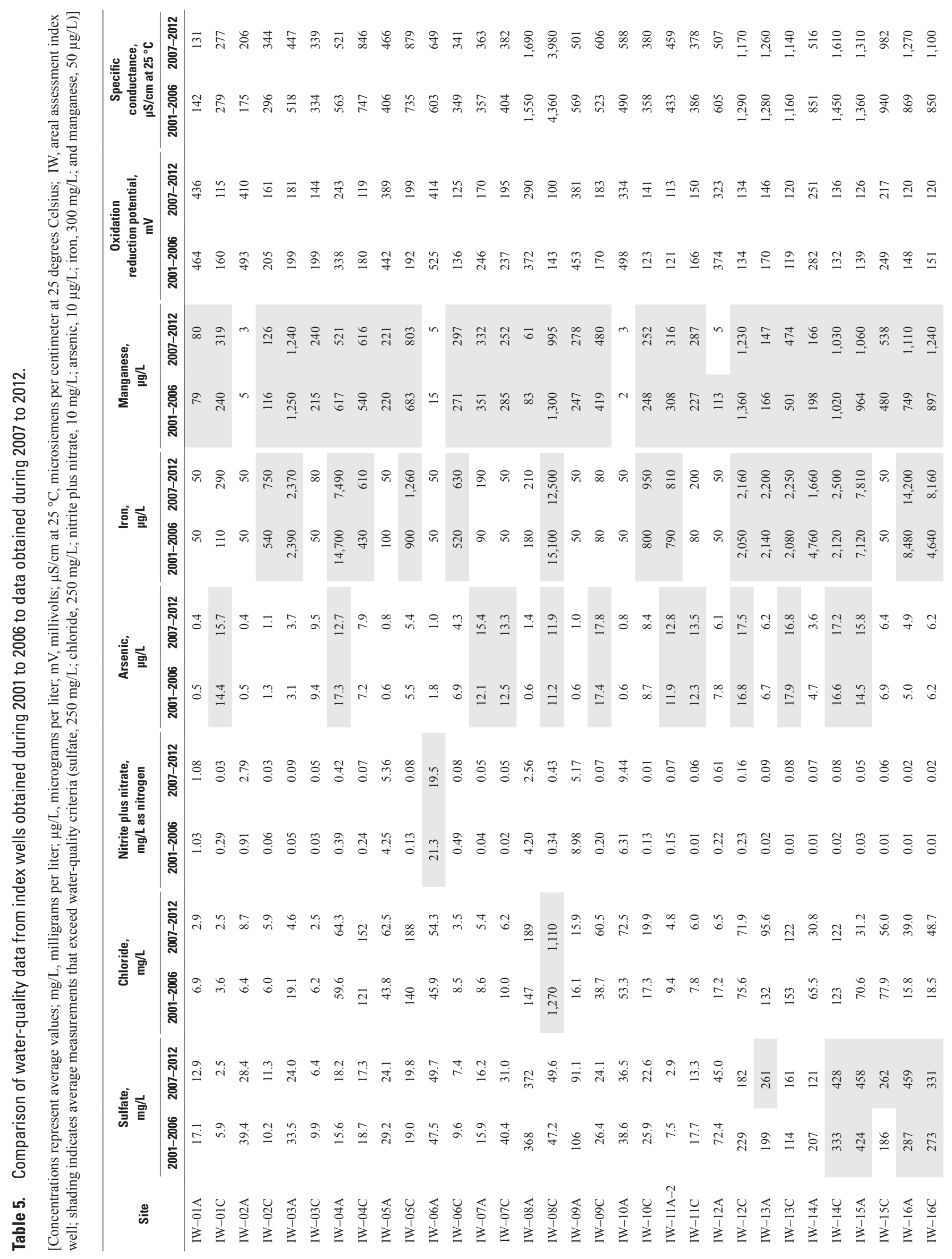




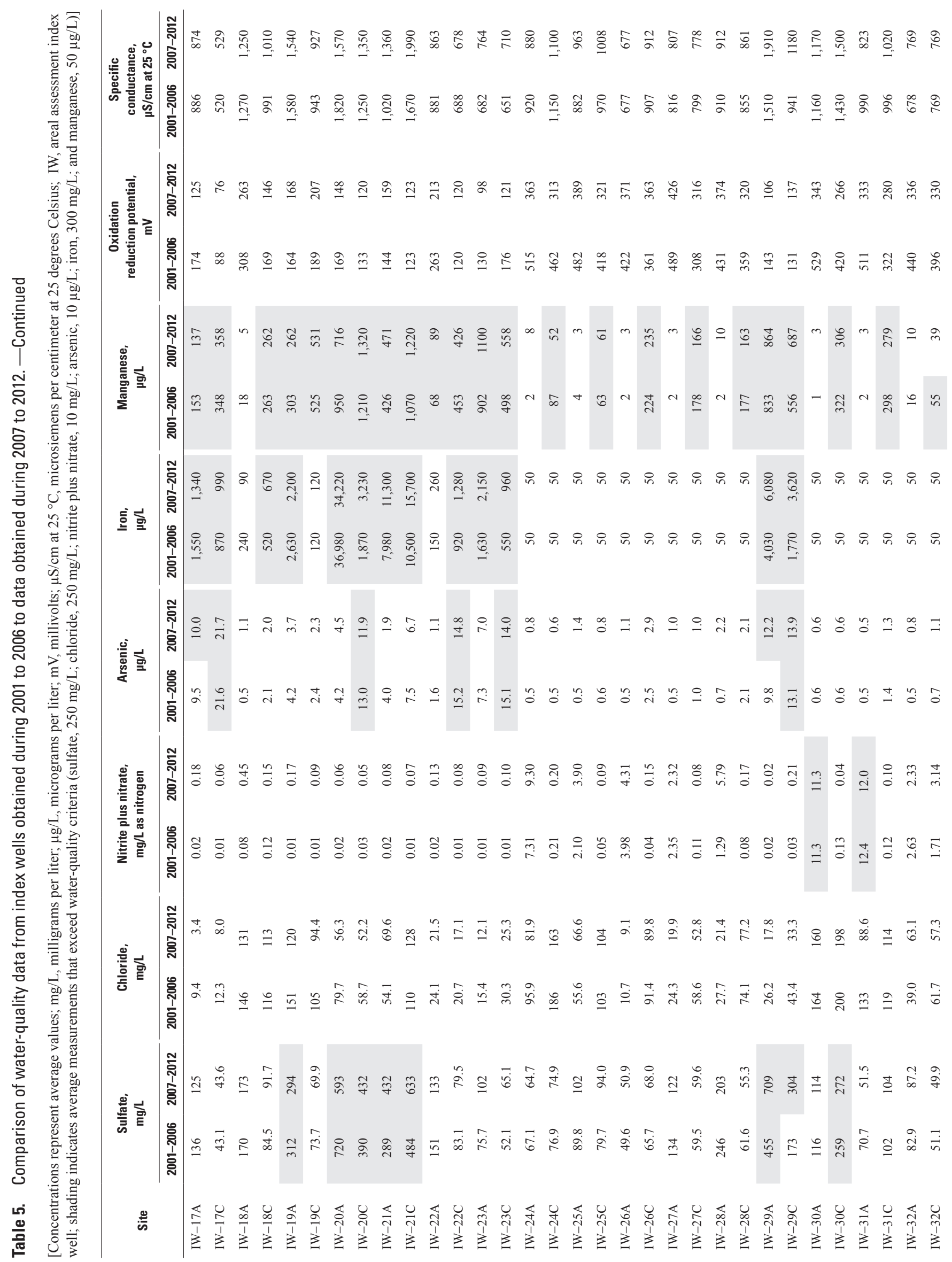




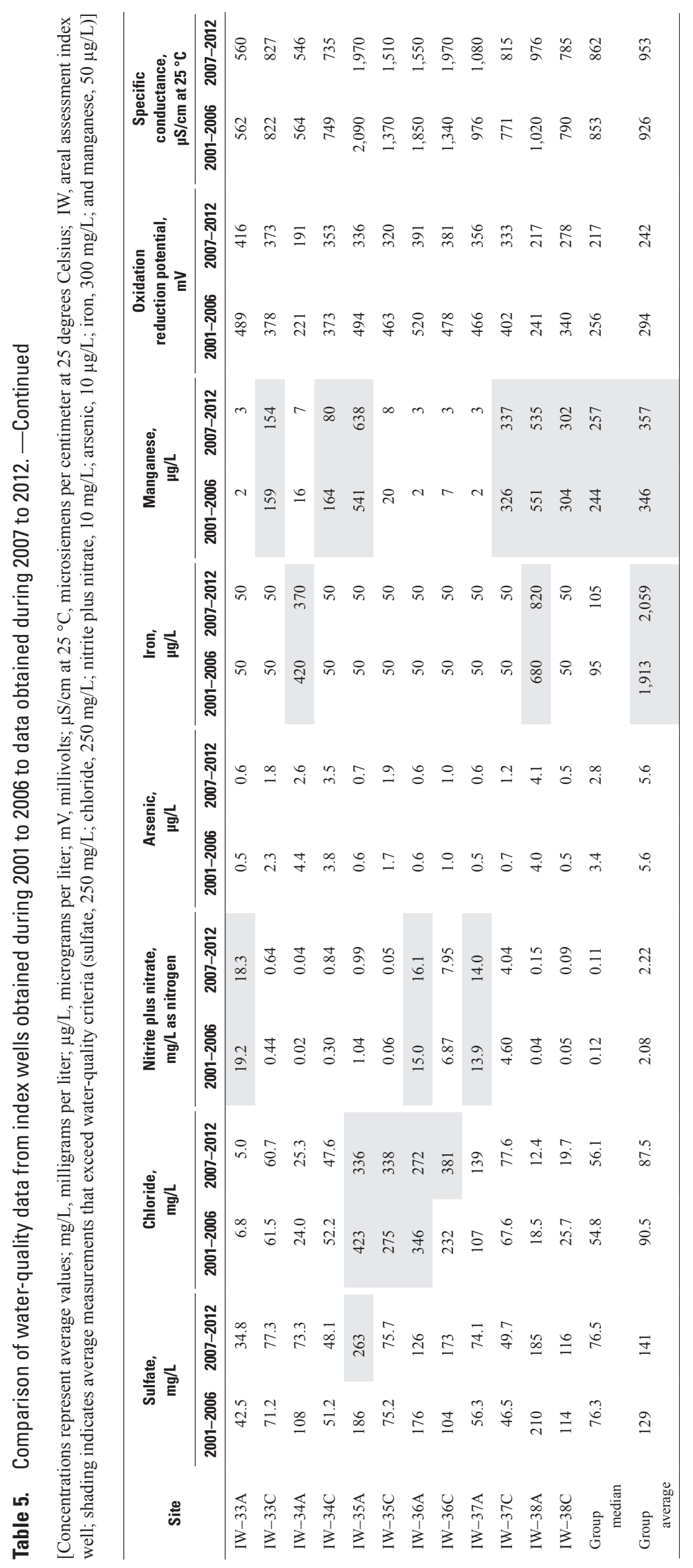


enhanced large scale recharge activities planned for 2013 and beyond associated with Phase II of the ASR project.

Constituents and physical properties of interest for each of the shallow and deep IWs include arsenic, chloride, iron, manganese, nitrate, ORP, specific conductance, and sulfate. As a group, all of the constituents of interest except chloride, arsenic, and ORP had the average value increase from the 2001 to 2006 period to the 2007 to 2012 period in the IW network (table 5). The median values for constituent well averages increased for sulfate, chloride, iron, manganese, and specific conductance from the first period to the second, while nitrate, arsenic, and ORP decreased (table 5). The iron concentration increases are likely linked to the decrease in ORP. The average concentration increases of constituents of interest and the ORP decrease from 2006 to 2012 is likely linked to drought conditions during 2011-2012 (fig. 4A). Lower precipitation amounts limit the diluting effect of new-water recharge.

\section{Physical Properties}

Physical properties were measured onsite during sample collection and include streamflow, groundwater level, specific conductance, $\mathrm{pH}$, water temperature, turbidity, dissolved oxygen, and ORP. The physical properties discussed in detail in this report are specific conductance and ORP because these properties are closely related to several water-quality constituents of concern (specific conductance and ions/trace metals, ORP and dissolved trace elements, and so on).

\section{Specific Conductance}

Specific conductance measures the ability of water to conduct an electrical current and is an indirect measurement of the presence of inorganic dissolved solids in water (Hem, 1992). Previous studies have successfully used specific conductance to compute concentrations of water-quality constituents, such as sulfate and chloride, in surface water in the Little Arkansas River (Christensen and others, 2000, 2003). Specific conductance measurements in water samples collected from surface water sites during 1995 through 2012 ranged from 134 to 3,220 microsiemens per centimeter at 25 degrees Celsius $\left(\mu \mathrm{S} / \mathrm{cm}\right.$ at $\left.25^{\circ} \mathrm{C}\right)$, with a median value of $1,080 \mu \mathrm{S} / \mathrm{cm}$ at $25^{\circ} \mathrm{C}$. Specific conductance measurements by the continuous monitoring sensors during 1999 through 2012 at the surface water monitoring sites on the Little Arkansas River near Halstead, Kans., and near Sedgwick, Kans., were within the range of those measured in water samples collected at these sites.

High specific conductance (larger than $1,000 \mu \mathrm{S} / \mathrm{cm}$ at $25^{\circ} \mathrm{C}$ ) was measured along parts of Kisiwa Creek and the Arkansas River in shallow and deep parts of the aquifer (fig. 1; figs. $9 A$ and $9 B$ ). The area of highest specific conductance in deep parts of the aquifer during 2006 through 2012 was near Burrton, Kans. (fig. 9B), and is associated with past oil and gas activities (Williams and Lohman, 1949; Whittemore, 2007). Areas of high specific conductance generally corresponded to areas of larger effective porosity near Burrton, Kans., and along the Arkansas River (fig. 8). Distribution of specific conductance in the Equus Beds aquifer has not changed substantially since 1979 and 1980 when Hathaway and others (1981) reported the highest specific conductance values near Burrton, Kans., south of Kisiwa Creek, and along the Arkansas River, whereas low values occurred in the northern and eastern parts of the study area of the Equus Beds Groundwater Recharge Project.

\section{Oxidation-Reduction Potential (ORP)}

ORP is measured in millivolts $(\mathrm{mV})$ relative to the standard hydrogen electrode, and indicates the ability of constituents in water to undergo oxidation or reduction reactions (Ziegler and others, 2010). ORP was reported only in groundwater samples. Larger ORP values represent conditions with an increased oxidation potential. For example, ORP values of more than $250 \mathrm{mV}$ indicate that the dominant iron species in groundwater was ferric iron, which can lead to chemical precipitation of iron hydroxides in aquifer material and can decrease the effective porosity. If ORP is less than $250 \mathrm{mV}$, more reducing conditions may cause reduction of nitrate and dissolution of arsenic, iron, and manganese in aquifer materials, thereby leading to larger dissolved concentrations of these constituents in groundwater. Even more reducing conditions involve geochemical and biological processes that convert dissolved sulfate to hydrogen sulfide gas. As a result, reduced areas (low ORP values) are expected to have lower dissolved sulfate or nitrate concentrations.

Average ORP in the shallow parts of the aquifer indicate more reducing conditions (ORP less than $250 \mathrm{mV}$ ) along parts of Kisiwa Creek and the Little Arkansas River (fig. 10A; fig. 1). In the deep parts of the aquifer, most of the southern part of the study area (Sedgwick County) was more oxidizing than the northern part (Harvey County; fig. 10B; fig. 1). This generally corresponded to larger effective porosity values (more sandy material) in the southern part of the study area (fig. 8).

\section{Major lons}

Dissolution of rocks and minerals is the primary source for most major ions in water (Hem, 1992). Primary sources of chloride in the study area are from past oil and gas activities near Burrton, Kans., naturally occurring saline water from the Arkansas River, municipal wastewater, industrial discharges, and mineralized water from the underlying Wellington Formation (Ziegler and others, 1999; Whittemore, 2007). Major ion constituents analyzed in water samples collected for this study include calcium, magnesium, potassium, sodium, bicarbonate, carbonate, bromide, chloride, fluoride, and sulfate. Summaries of these constituent concentrations for the study area are available online (http://ks.water.usgs.gov/equus-water-quality, December 2013). 


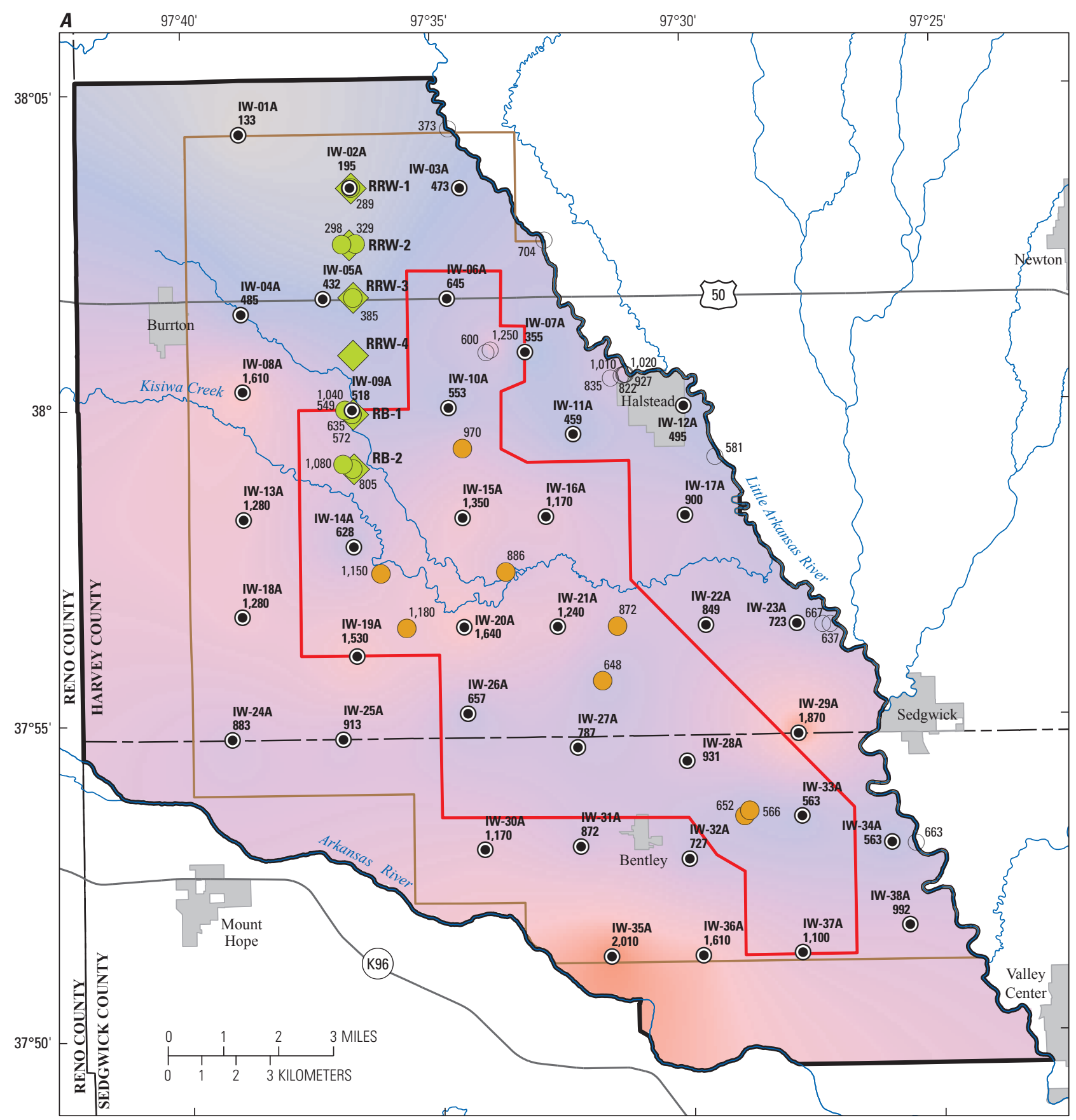

Base from U.S. Geological Survey digital data, 1:24,000, 2012

Universal Transverse Mercator projection, zone 14

Horizontal coordinate information is referenced to the

North American Datum of 1983 (NAD 83)

EXPLANATION
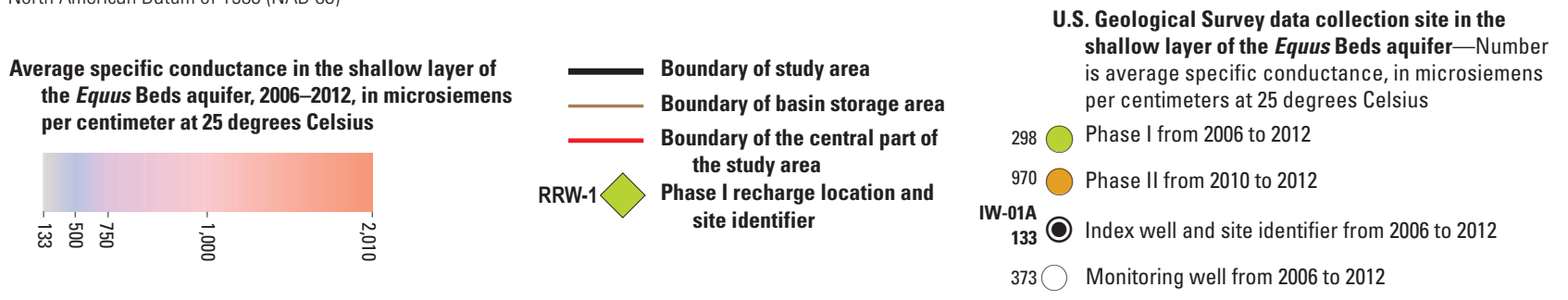

Figure 9. Average specific conductance in and near the study area, 2006-2012, south-central Kansas, in $A$, shallow wells and $B$, deep wells. 


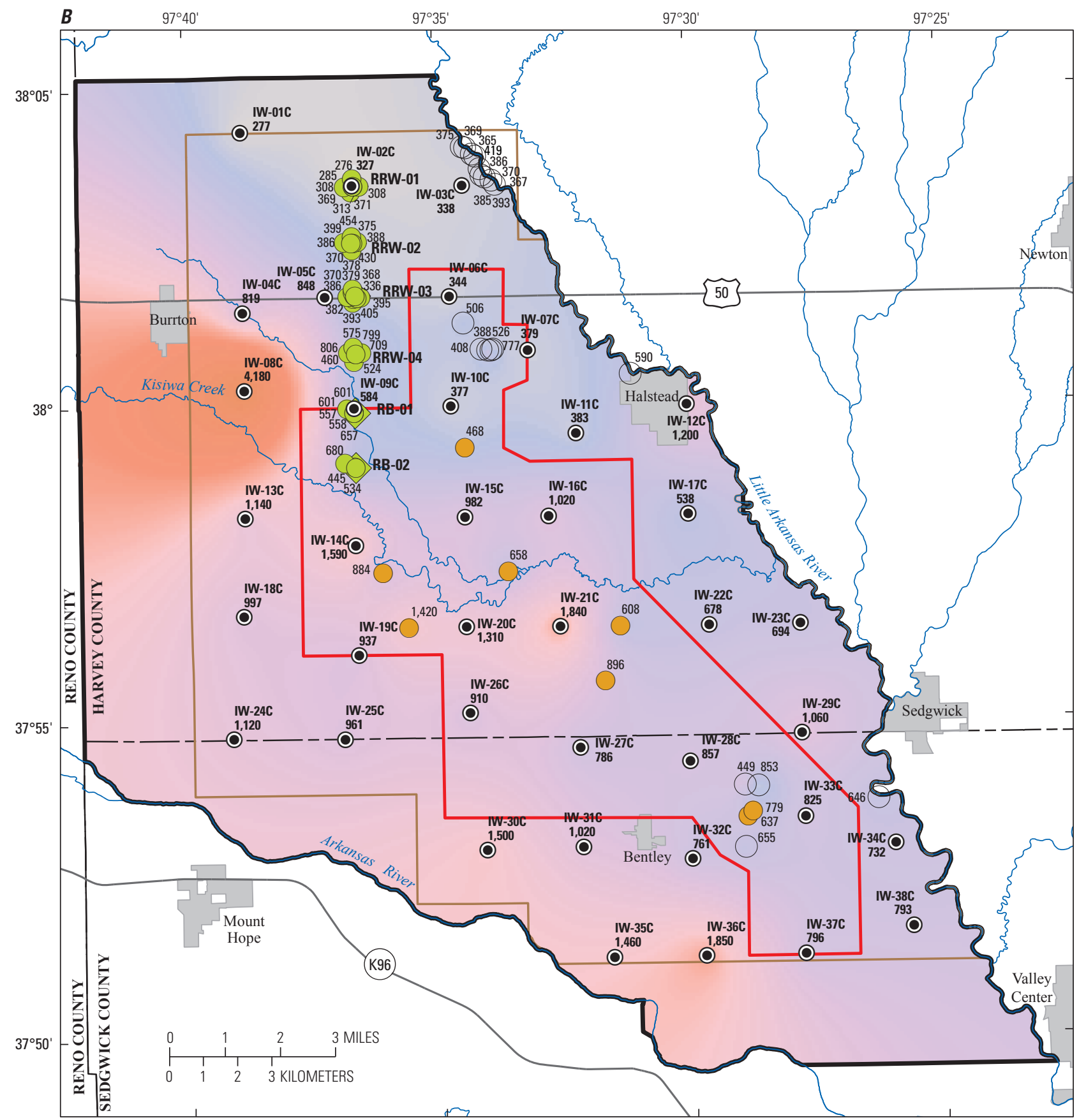

Base from U.S. Geological Survey digital data, 1:24,000, 2012

Universal Transverse Mercator projection, zone 14

Horizontal coordinate information is referenced to the

North American Datum of 1983 (NAD 83)

EXPLANATION
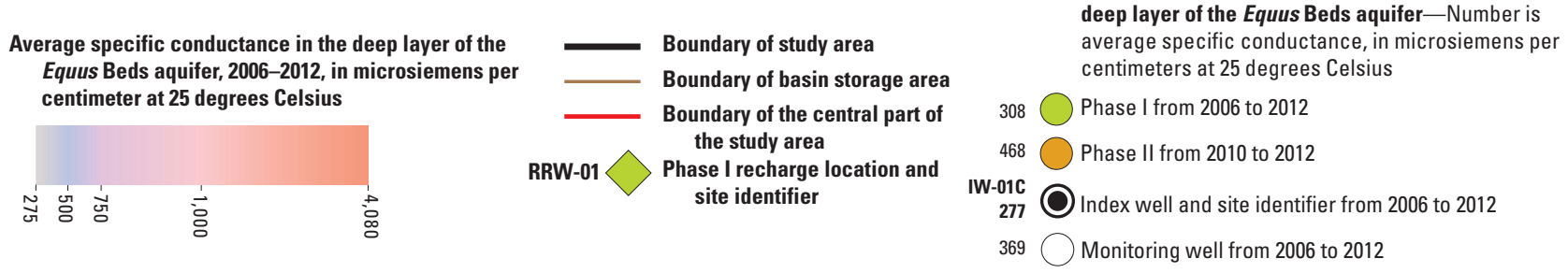

Figure 9. Average specific conductance in and near the study area, 2006-2012, south-central Kansas, in $A$, shallow wells and $B$, deep wells.-Continued 


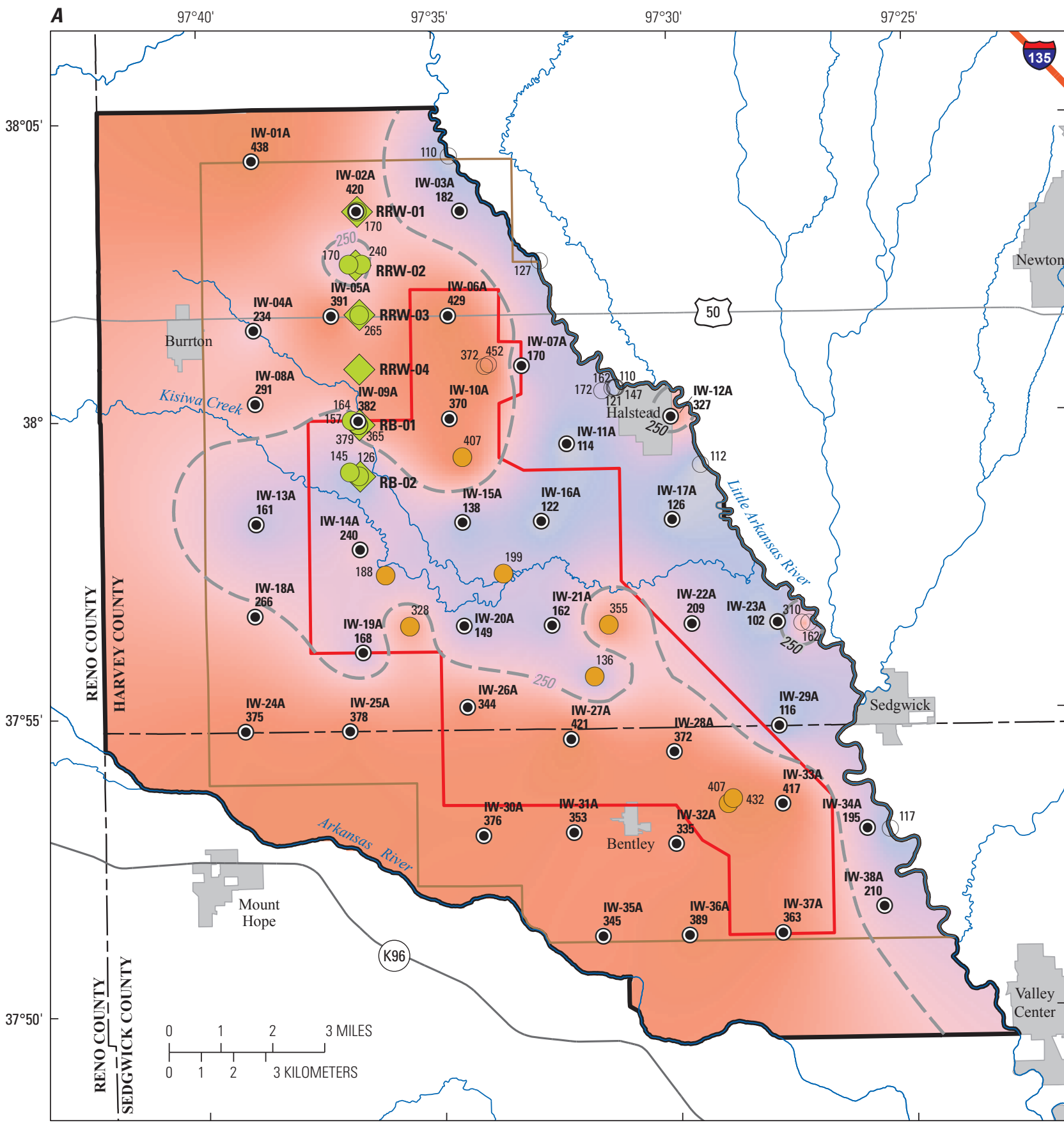

Base from U.S. Geological Survey digital data, 1:24,000, 2012 Universal Transverse Mercator projection, zone 14

Horizontal coordinate information is referenced to the North American Datum of 1983 (NAD 83)
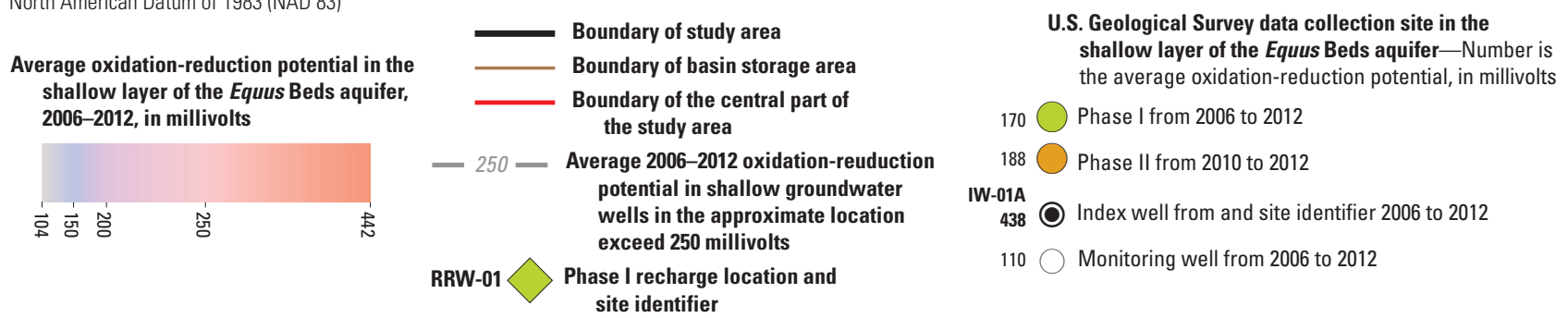

Figure 10. Average oxidation-reduction potential in and near the study area, 2006-2012, south-central Kansas, in $A$, shallow wells and $B$, deep wells. 


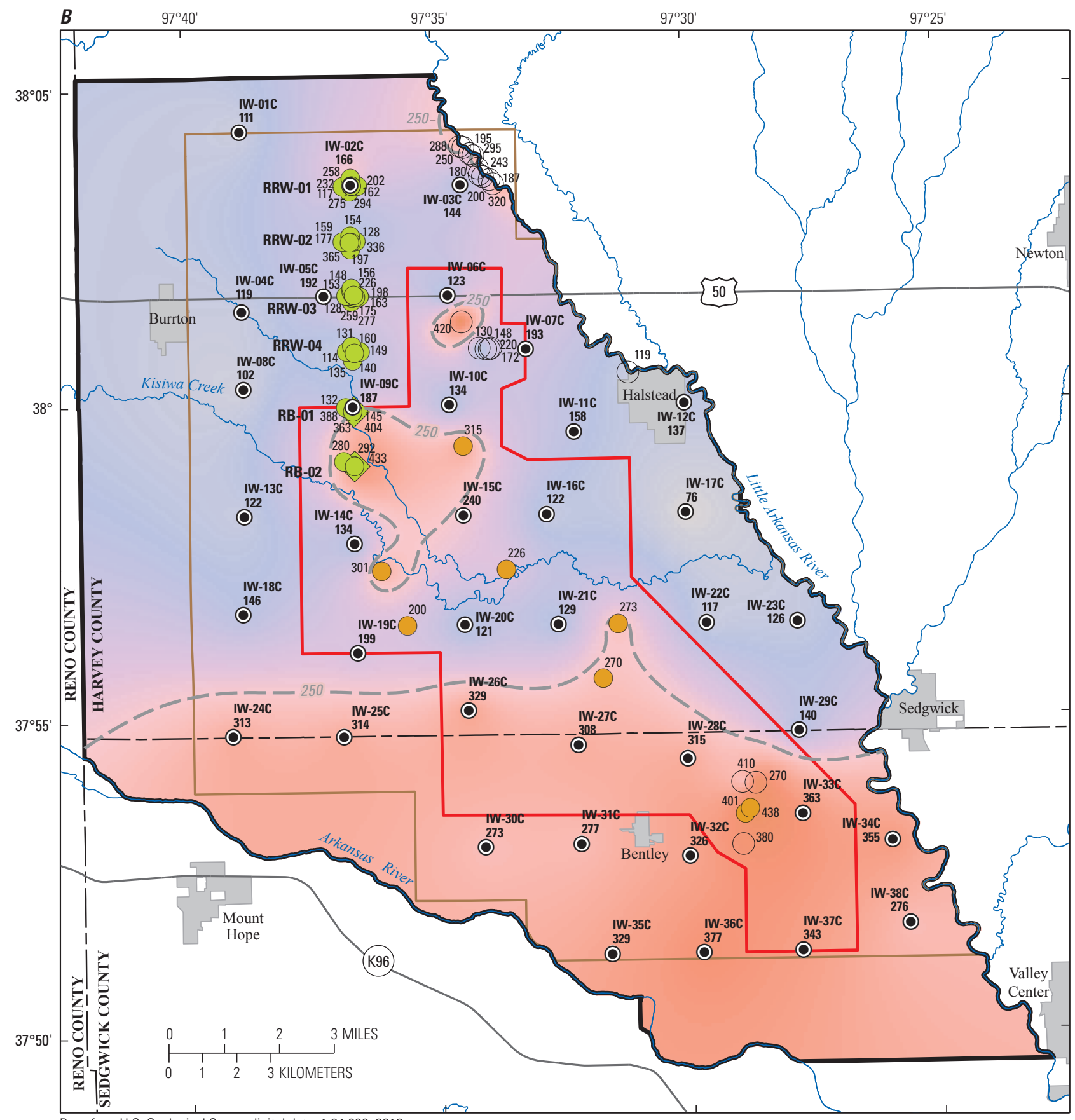

Base from U.S. Geological Survey digital data, 1:24,000, 2012

Universal Transverse Mercator projection, zone 14

Horizontal coordinate information is referenced to the

North American Datum of 1983 (NAD 83)

Average oxidation-reduction potential in the deep layer of the Equus Beds aquifer, 2006-2012, in millivolts

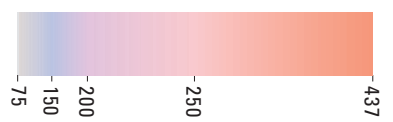

\section{EXPLANATION}

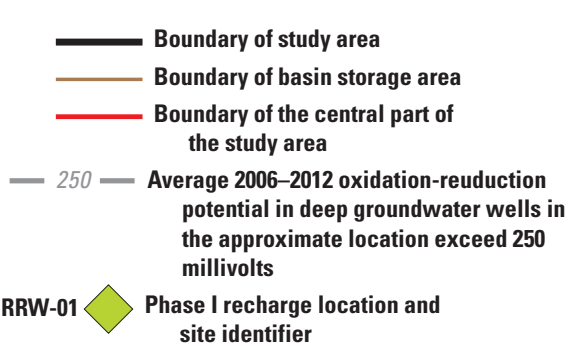

U.S. Geological Survey data collection site in the deep layer of the Equus Beds aquifer-Number is the average oxidation-reduction potential, in millivolts

$232 \bigcirc$ Phase I from 2006 to 2012

$315 \bigcirc$ Phase II from 2010 to 2012

W-01C

111 Index well and site identifier from 2006 to 2012

$230 \bigcirc$ Monitoring well from 2006 to 2012

Figure 10. Average oxidation-reduction potential in and near the study area, 2006-2012, south-central Kansas, in $A$, shallow wells and $B$, deep wells.-Continued 
Groundwater in the Equus Beds aquifer is predominantly a calcium bicarbonate type changing to a sodium chloride type in some areas (Leonard and Kleinschmidt, 1976). The groundwater near the Arkansas River is a calcium sodium chloride type. Farther away from the Arkansas River, the dominant groundwater is a calcium bicarbonate type.

Large concentrations of major ions are objectionable in drinking water because of possible physiological effects, unpalatable mineral tastes, and greater costs resulting from corrosion or the need for additional treatment (U.S. Environmental Protection Agency, 1986). Sodium, sulfate, and chloride frequently exceed water-quality criteria in the study area. Sulfate and chloride are discussed in detail in this report because of the potential for saltwater migration from the Burrton oil field and the Arkansas River into the Equus Beds aquifer.

\section{Sulfate}

Sulfate is a major ion of importance for artificial recharge. Natural sources of sulfate in surface water and groundwater are rock weathering, oxidation of sulfide minerals, and biological processes. The primary anthropogenic sources of sulfate in water are atmospheric deposition from the combustion of coal and petroleum products, and irrigation return flows (Ziegler and others, 2010). Sulfate contributes to dissolved-solids concentrations in water and is considered undesirable when exceeding $250 \mathrm{mg} / \mathrm{L}$, which is the Federal secondary maximum contaminant level (SMCL) established by the EPA (U.S. Environmental Protection Agency, 2009). Constituents exceeding Federal SMCLs do not create health issues for humans, but limits are set for aesthetic reasons (taste and odor), technical effects (corrosion and staining), and cosmetic effects.

Water samples collected from the Little Arkansas River near Halstead, Kans., and Sedgwick, Kans., during 1995 through 2012 had an average sulfate concentration of about $38 \mathrm{mg} / \mathrm{L}$ (table 3), which was substantially smaller than the SMCL. Sulfate concentrations ranged from less than 5 to $312 \mathrm{mg} / \mathrm{L}$ between the two surface water sites, and sulfate exceeded the SMCL in less than 1 percent of samples.

Christensen and others $(2000,2003)$ developed regression models to compute continuous concentrations of sulfate in the Little Arkansas River using continuously measured specific conductance as a surrogate. This model was used to compute concentrations of sulfate in the Little Arkansas River for 1999 through 2012. Data and regression model information are available at http://nrtwq.usgs.gov/ks/. Computed sulfate concentrations in the Little Arkansas River from 1999 through 2012 ranged from less than 3 to $93 \mathrm{mg} / \mathrm{L}$ near Halstead, Kans., and from less than 2 to $104 \mathrm{mg} / \mathrm{L}$ near Sedgwick, Kans. The largest sulfate concentration computed at the surface water sites on the Little Arkansas River was $104 \mathrm{mg} / \mathrm{L}$, which is substantially smaller than the largest measured concentration of $312 \mathrm{mg} / \mathrm{L}$. Computed median sulfate concentrations were
$45 \mathrm{mg} / \mathrm{L}$ at both Little Arkansas River sites during this 14-year study period.

The distribution of study area average sulfate concentrations in groundwater during 2006-2012 is shown in figure 11. In the shallow IWs, 18.7 percent of the samples exceeded the SMCL for sulfate (table 4) during 2001-2012, whereas water samples from 12.9 percent of the deep IWs had sulfate concentrations that exceeded $250 \mathrm{mg} / \mathrm{L}$ (table 4). Wells with average sulfate concentrations exceeding the SMCL are mostly located in the central part of the study area (figs. $11 A$ and $11 B$ ) where the aquifer is thickest (fig. 2), and generally associated with areas that were substantially dewatered through 1992 and have subsequently recovered (fig. 5).

Ziegler and others (2010) established that sulfate concentrations increased in the Equus Beds aquifer from 1979 to 2005 (Hathaway and others, 1981), and indicated that increased concentrations were likely the result of dewatering and subsequent oxidation of aquifer material during the modern historical water-level low of the early 1990s (figs. $4 A$ and $11 A$ ). Data presented in this report reveal sulfate concentrations have been continuing to increase since 2006, as the average concentration for all IWs was $141 \mathrm{mg} / \mathrm{L}$ during 2007-2012 compared to $129 \mathrm{mg} / \mathrm{L}$ during 2001-2006 (table 5). Sulfate is a charged ionic species that increases the specific conductance of water (Hem, 1992). Therefore, an increase in sulfate concentration can result in a corresponding increase in specific conductance. Similar to the average sulfate concentration increases since 2005, the average specific conductance for all IWs also increased during 2007-2012 compared to 2001-2006 (table 5). Sulfate concentrations can also be strongly related to oxidation-reduction properties of water (Hem, 1992); however, in Ziegler and others (2010), statistical analysis of ORP was not shown to be strongly related to sulfate in the Equus Beds aquifer.

\section{Chloride}

Sources of chloride in the Equus Beds aquifer include underlying rocks and past disposal of oil-field brines. Natural water from the unconsolidated aquifer normally contains less than $100 \mathrm{mg} / \mathrm{L}$ chloride, whereas larger concentrations (100 to $500 \mathrm{mg} / \mathrm{L}$ ) are common in the western part of the study area near the Burrton oil field and along the Arkansas River (fig. 1; Ziegler and others, 2010). Chloride concentrations in the Arkansas River averaged about $600 \mathrm{mg} / \mathrm{L}$ from 1988 through 1991 (Myers and others, 1996). Concentrations of chloride in the Arkansas River between Hutchison, Kans., and Maize, Kans., averaged about $500 \mathrm{mg} / \mathrm{L}$ during 1997 through 2006 (Kansas Department of Health and Environment, 2006a). Upwelling of brines from the underlying Permian salt beds enters tributaries upstream from Hutchison, Kans. (not shown), that flow into the Arkansas River (fig. 1; Kansas Department of Health and Environment, 2006a; Whittemore, 2007). Additionally, irrigation practices in western Colorado increase and prolong surface exposure to evaporation, subsequently leaving the remaining water that reenters the Arkansas 


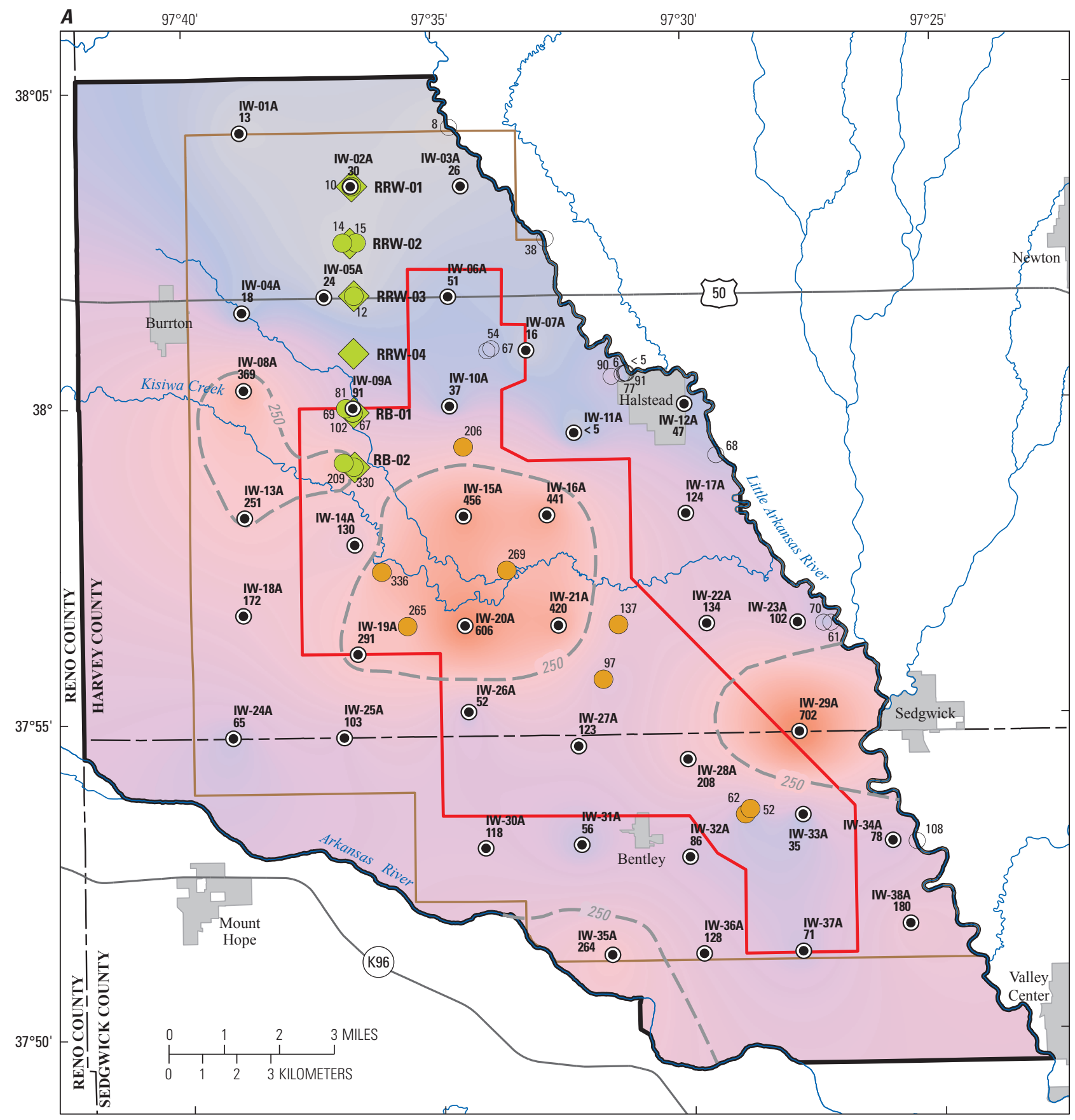

Base from U.S. Geological Survey digital data, 1:24,000, 2012

Universal Transverse Mercator projection, zone 14

Horizontal coordinate information is referenced to the

North American Datum of 1983 (NAD 83)

Average sulfate concentration in the shallow layer of the Equus Beds aquifer, 2006-2012, in milligrams per liter

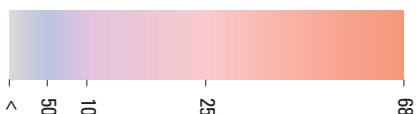

जि 당 तु

- 250 - Average 2006-2012 sulfate concentration in shallow groundwater wells in the approximate location exceed the U.S. Enviornmental Protection Agency's national secondary drinking water

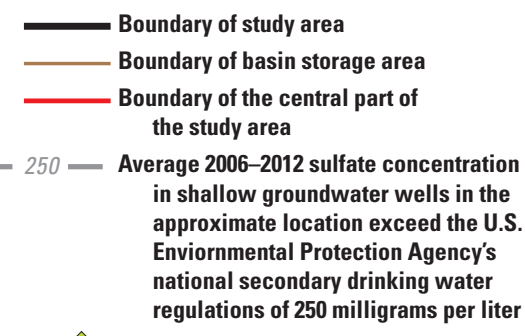

RRW-01 Phase I recharge location and site identifier
U.S. Geological Survey data collection site in the shallow layer of the Equus Beds aquifer-Number is the average sulfate concentration, in milligrams per liter

$14 \bigcirc$ Phase I from 2006 to 2012

$206 \bigcirc$ Phase II from 2010 to 2012

IW-01A

13 Index well and site identifier from 2006 to 2012

$8 \bigcirc$ Monitoring well from 2006 to 2012

Figure 11. Average sulfate concentrations in the study area, 2006-2012, south-central Kansas, in $A$, shallow wells and $B$, deep wells. 


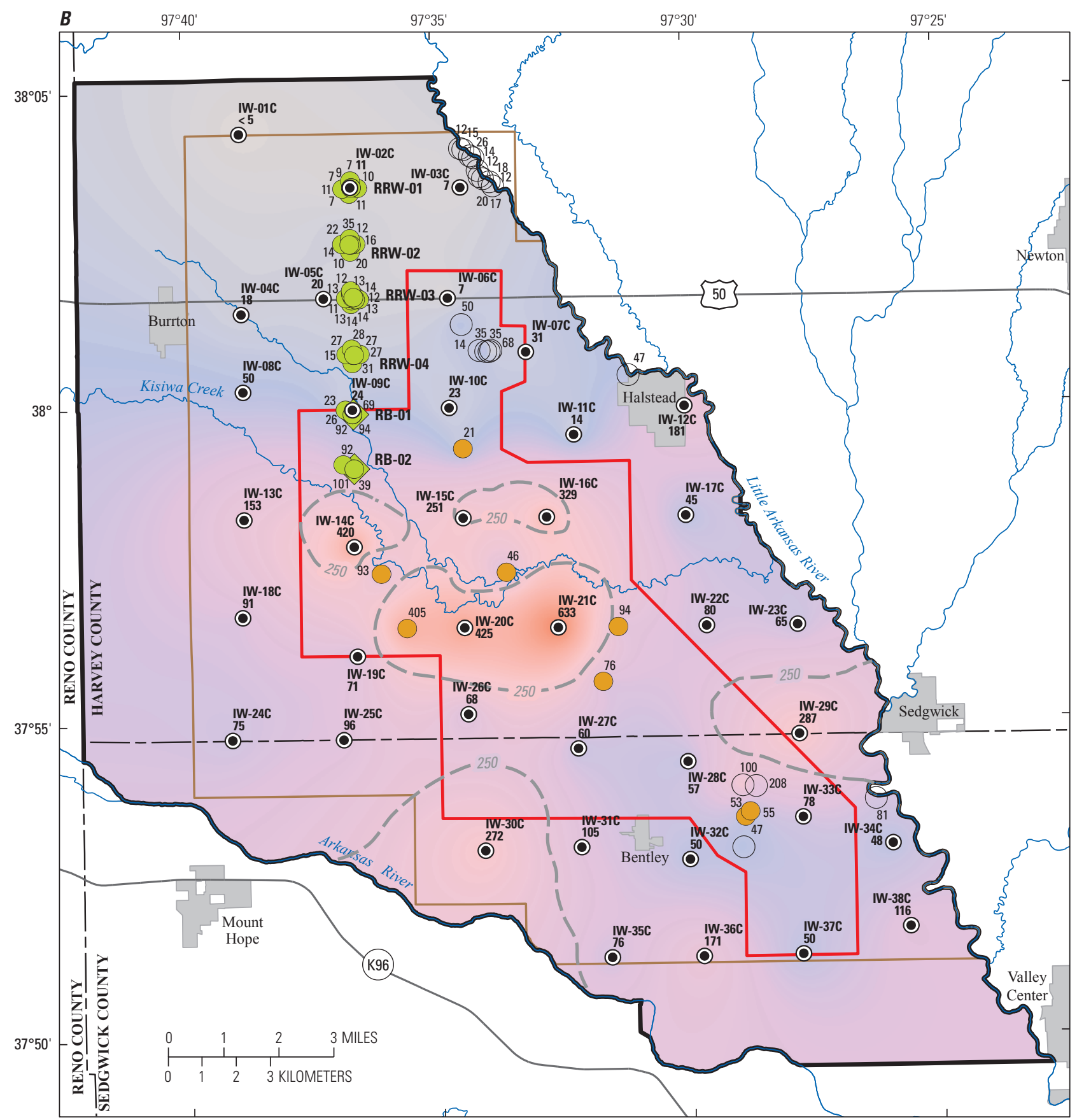

Base from U.S. Geological Survey digital data, 1:24,000, 2012 EXPLANATION Universal Transverse Mercator projection, zone 14

Horizontal coordinate information is referenced to the

North American Datum of 1983 (NAD 83)

Average sulfate concentration in the deep layer of the Equus Beds aquifer, 2006-2012, in milligrams per liter

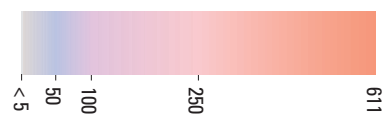

Boundary of study area

Boundary of basin storage area

Boundary of the central part of the study area

- 250 - Average 2006-2012 sulfate concentration in deep groundwater wells in the approximate location exceed the U.S. Enviornmental Protection Agency's national secondary drinking water regulations of 250 milligrams per liter

RRW-01 Phase I recharge location and
U.S. Geological Survey data collection site in the deep layer of the Equus Beds aquifer-Number is the average sulfate concentration, in milligrams per liter

7 Phase I from 2006 to 2012

$21 \bigcirc$ Phase II from 2010 to 2012

IW-01C

$<5 \bigcirc$ Index well and site identifier from 2006 to 2012

$12 \bigcirc$ Monitoring well from 2006 to 2012 site identifier

Figure 11. Average sulfate concentrations in the study area, 2006-2012, south-central Kansas, in $A$, shallow wells and $B$, deep wells.Continued 
River with higher dissolved ion concentrations (Whittemore, 2000). Sources of chloride in the Little Arkansas River also include contamination from past oil and gas activities near McPherson, Kans. (not shown), and municipal and industrial wastewater discharges (Leonard and Kleinschmidt, 1976; Kansas Department of Health and Environment, 2006b; Schmidt and others, 2007; Whittemore, 2007).

The EPA Federal SMCL for chloride is $250 \mathrm{mg} / \mathrm{L}$ (U.S. Environmental Protection Agency, 2009). When chloride concentrations are larger than $250 \mathrm{mg} / \mathrm{L}$, consumers detect a bleach-like odor and salty taste in the water. In addition, large concentrations of chloride can contribute to corrosion and staining of plumbing and fixtures (U.S. Environmental Protection Agency, 2005). Irrigation water with concentrations exceeding $350 \mathrm{mg} / \mathrm{L}$ chloride is likely to cause adverse effects on crops (Bauder and others, 2007).

Chloride concentrations in water samples collected from the Little Arkansas River near Halstead, Kans., and near Sedgwick, Kans., ranged from less than 5 to $932 \mathrm{mg} / \mathrm{L}$ during 1995 through 2012 (table 3). The Federal SMCL for chloride was exceeded in about 11 percent of the samples collected from the 2 surface water monitoring sites on the Little Arkansas River during 1995 through 2012 (table 3). Chloride concentrations were less than the SMCL for all samples at Phase I source sites (table 4).

Continuous chloride concentrations in the Little Arkansas River were computed based on specific conductance measurements using regression models from Christensen and others (2003) for the period 1999 through 2012. Median computed chloride concentration was $166 \mathrm{mg} / \mathrm{L}$ in the Little Arkansas River near Halstead, Kans., and exceeded $250 \mathrm{mg} / \mathrm{L}$ about 20 percent of the time during 1999 through 2012 (fig. 12). Median computed chloride in the Little Arkansas River near Sedgwick, Kans., was about $85 \mathrm{mg} / \mathrm{L}$ and exceeded $250 \mathrm{mg} / \mathrm{L}$ less than 1 percent of the time during 1999 through 2012 (fig. 12). Larger specific conductance and chloride concentrations generally corresponded with low-flow conditions. Chloride concentrations likely are smaller at the downstream Sedgwick site, relative to the Halstead site, because of dilution from groundwater inflow containing smaller chloride concentrations.

Chloride concentrations exceeded the SMCL in 5.6 percent of the water samples from IWs in the shallow parts of the aquifer during 2001 through 2012 (table 4). Shallow wells with average concentrations of chloride larger than the SMCL are near Burrton, Kans., and along the Arkansas River (fig. 13A). Average chloride concentrations during 2006-12 in the deep parts of the Equus Beds aquifer are shown in figure $13 B$, and chloride concentrations exceeded the SMCL in about 7.4 percent of the water samples from deep IWs during 2001 through 2012 (table 4). Similar to the shallow parts of the aquifer, concentrations exceeding $250 \mathrm{mg} / \mathrm{L}$ were detected in wells located near Burrton, Kans., and along the Arkansas River. An exception to the high chloride concentrations near the Arkansas River occurs south of Bentley, Kans. in the deep parts of the aquifer, which is also near the location of the bedrock low (fig. 13B). Average chloride concentrations at all IWs (shallow and deep) decreased during 2007-2012 compared to 2001-2006 averages; however, median chloride concentrations increased from the first period to the second (table 5).

Chloride movement through the Equus beds aquifer is complex because of discontinuous clay and sand layers. The clay layers act as aquitards, slowing the vertical movement of groundwater, whereas sand layers allow the groundwater to flow. Between the periods of 1982-1984 and 1995-2005, the Burrton chloride plume has advanced east and southeast (fig. 14) following the general direction of groundwater flow (fig. 3). The location of the chloride concentrations exceeding $250 \mathrm{mg} / \mathrm{L}$ in deep groundwater continued to move to the east and south during 2006-2012 relative to 1995-2005 and

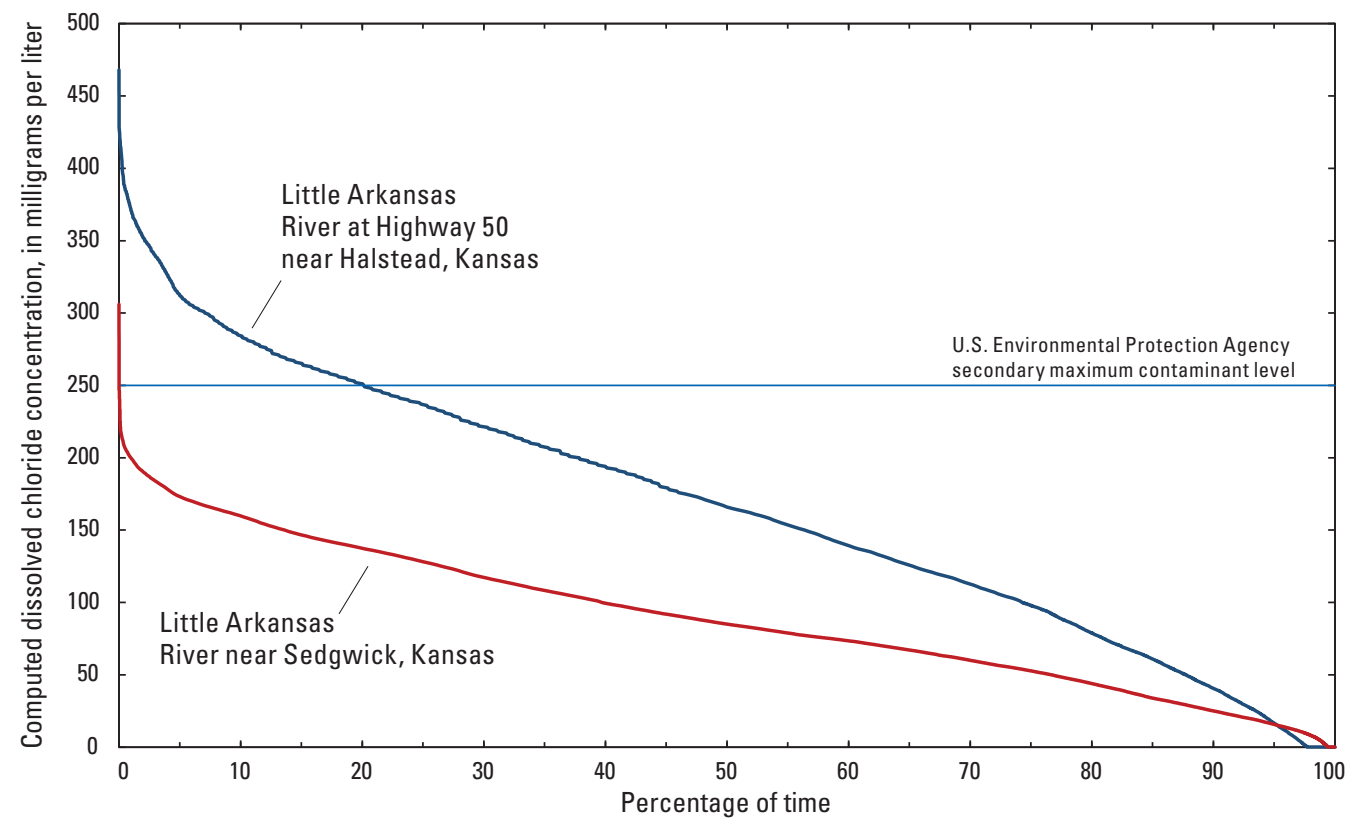

Figure 12. Duration curves of computed dissolved chloride concentrations, 1999-2012, Little Arkansas River near Halstead and near Sedgwick, Kansas. 


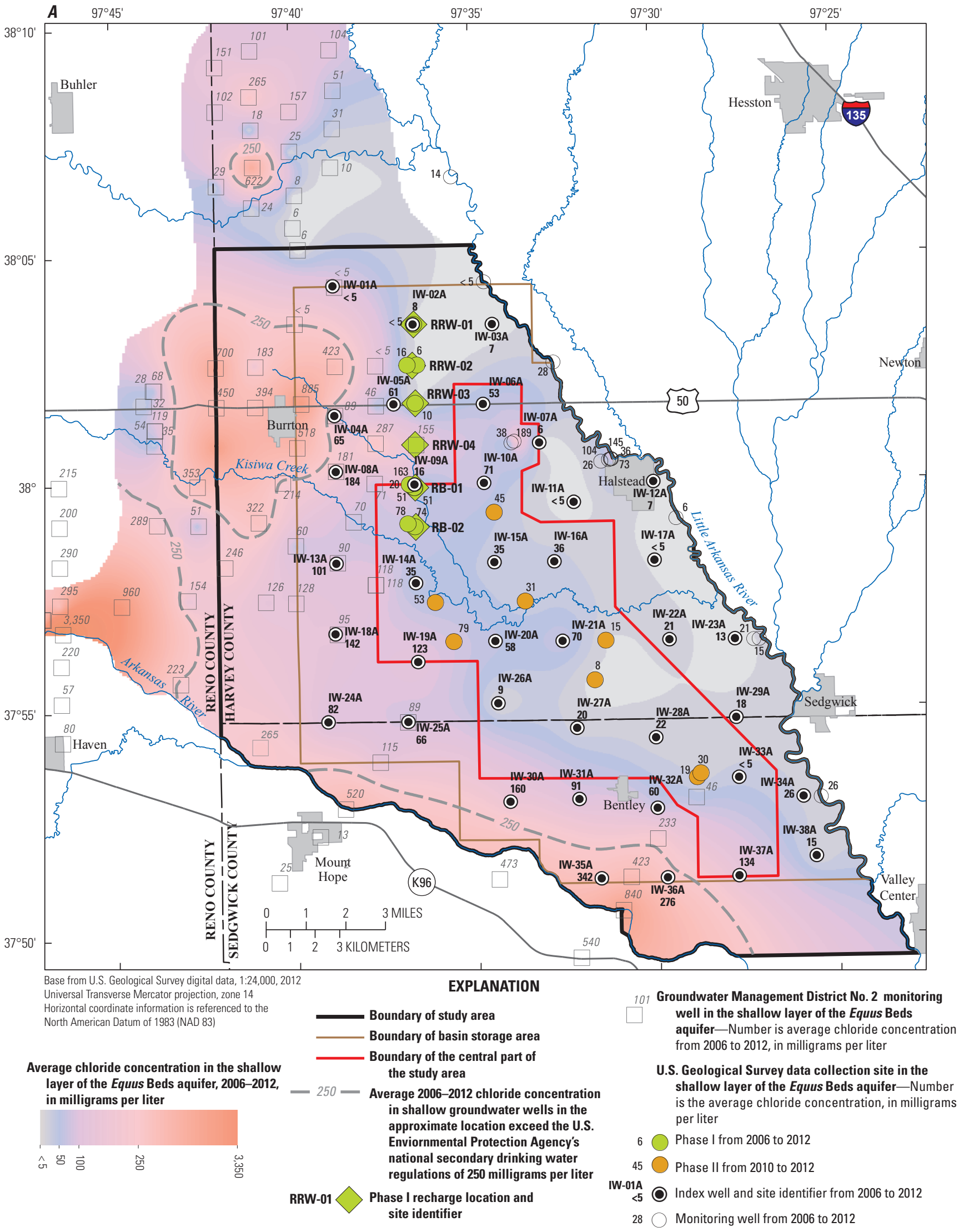

Figure 13. Average chloride concentrations in and near the study area 2006-2012, south-central Kansas, for $A$, shallow wells and $B$, deep wells. 


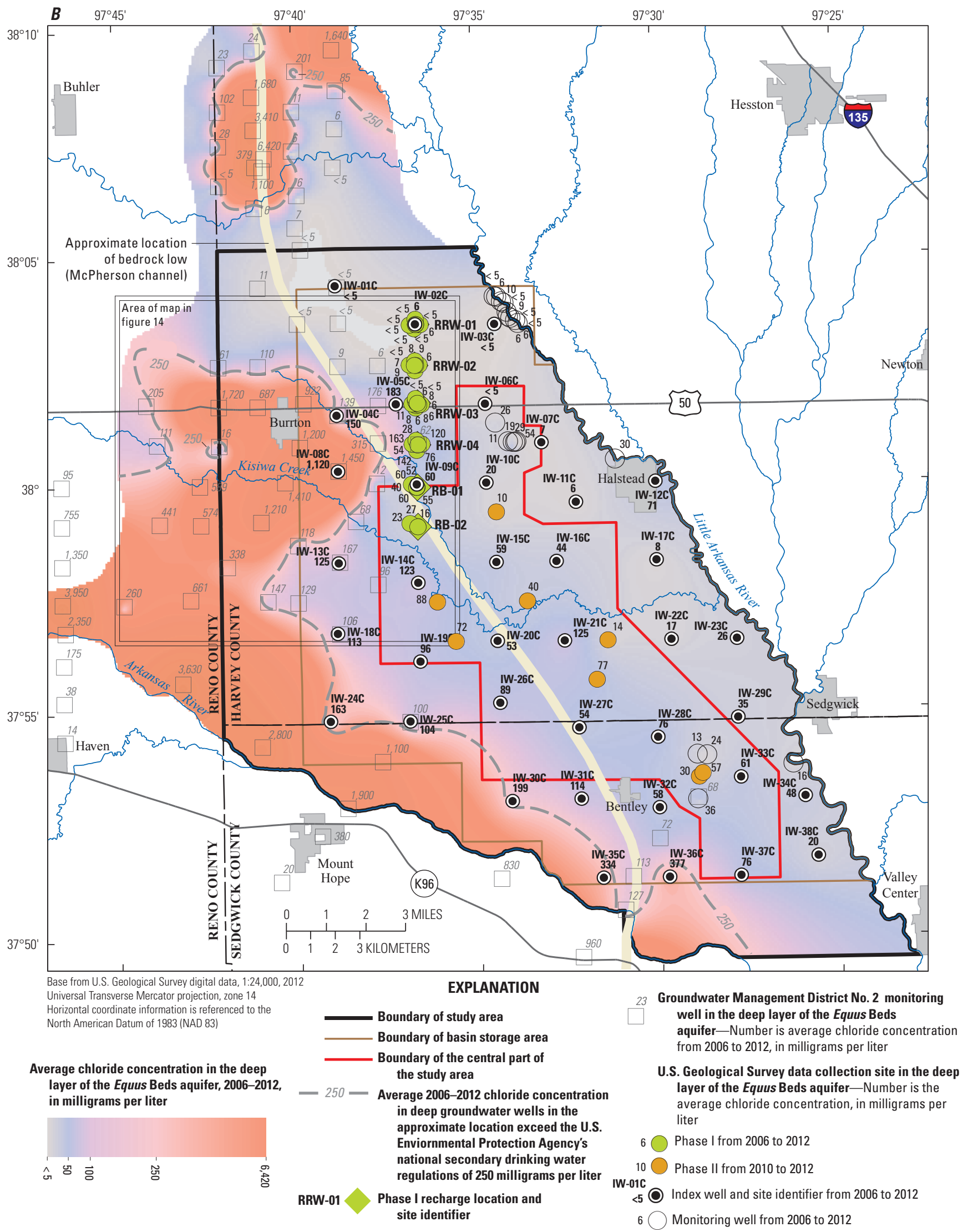

Figure 13. Average chloride concentrations in and near the study area 2006-2012, south-central Kansas, for $A$, shallow wells and $B$, deep wells.-Continued 


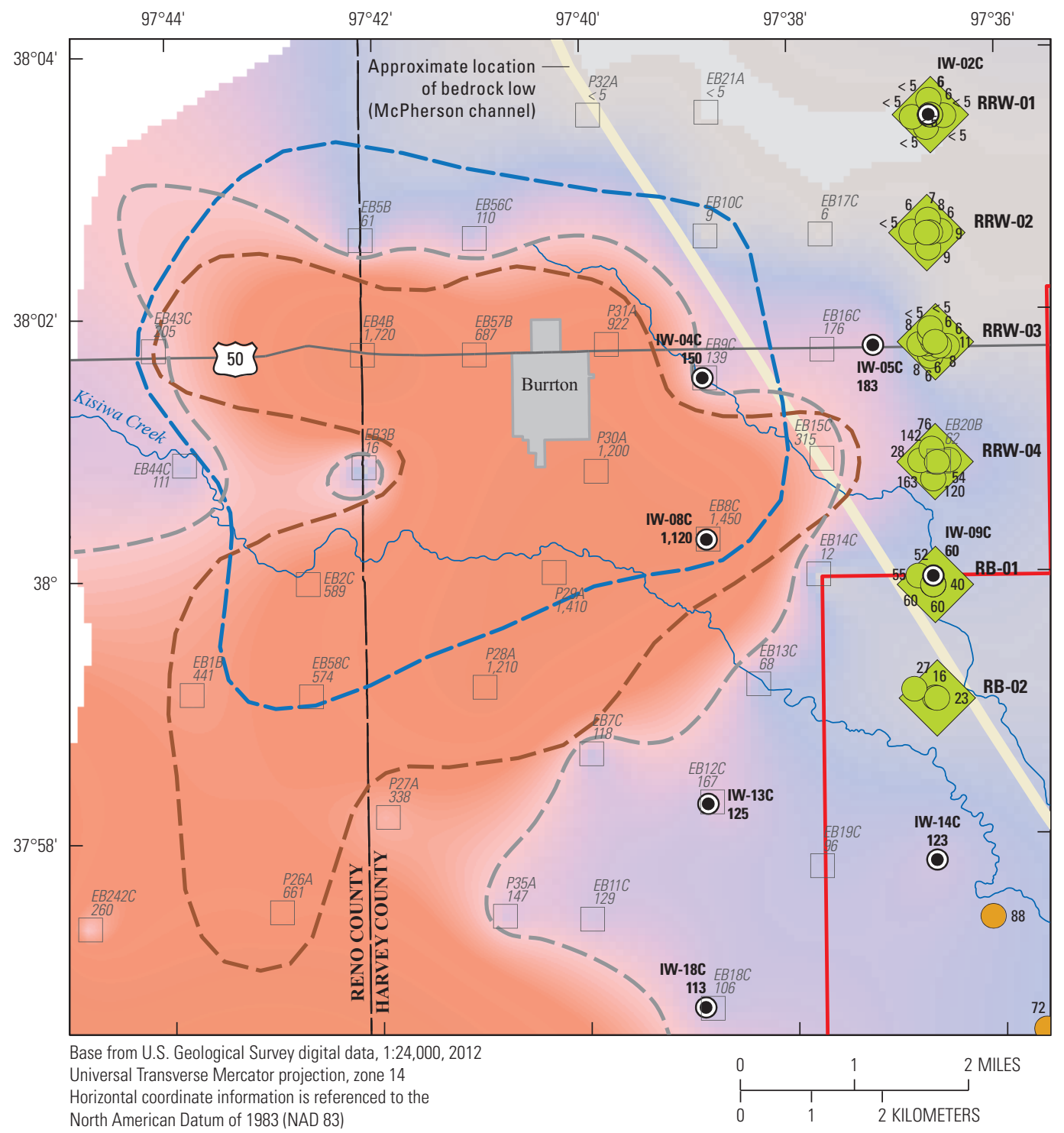

EXPLANATION

Average chloride concentration in the deep layer of the Equus Beds aquifer, 2006-2012, in milligrams per liter

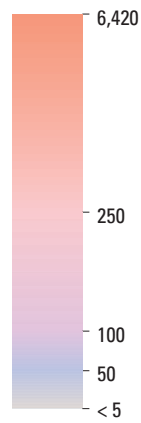

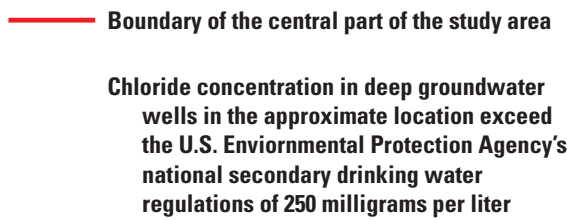

_ - Average 1982-984 (modified from Whittemore, 2007)

_ $\quad$ Average 1995-2005 (data from Zieglers and others, 2010) - Average 2006-2012

RRW-01

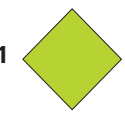

Phase I recharge location and site identifier
Groundwater Management District No. 2 monitoring well in the deep layer of the Equus Beds aquifer-Number is average chloride concentration from 2006 to 2012, in milligrams per liter

U.S. Geological Survey data collection site in the deep layer of the Equus Beds aquifer-Number is the average chloride concentration, in milligrams per liter

Phase I from 2006 to 2012

$88 \bigcirc$ Phase II from 2010 to 2012

IW-02C

6 ○ Index well and site identifier from 2006 to 2012

$6 \bigcirc$ Monitoring well from 2006 to 2012

Figure 14. Changes in chloride concentration near Burrton, Kansas during 1982-2012. 
1982-1984 averages. The chloride increases in the southernmost part of figure 14 during 2006-2012 likely represent enhanced chloride contributions to groundwater from the naturally saline Arkansas River (fig. 13B; fig. 14), this is inferred from the direction of groundwater flow in the area (fig. 3).

The injected water as part of ASR Phase I is expected to decrease the local groundwater gradient, and slow or impede the movement of the groundwater to the east. The eastward movement of the Burrton chloride plume is likely being slowed by a line of recharge locations associated with ASR Phase I; however, the line depicting average chloride concentrations in deep groundwater during 2006-2012 still advanced to less than one half mile from the central part of the study area (fig. 14). Additional evidence of the Burrton chloride plume impediment or dilution can be seen in the graph of chloride concentrations in deep well IW-05 and the amount of water recharged associated with ASR Phase I at RRW-03 (fig. 15). The IW-05 nest is about 0.5 mi west of RRW-03. Chloride concentrations increased during 2001 through 2005 at IW-05, followed by a period of annual fluctuations but little overall change in chloride concentrations during 2005 through 2010. Full-scale artificial recharge began in 2007, indicating the non-increasing chloride concentrations during the 2005 through 2010 period was likely in part due to artificial recharge. After 2010, chloride concentrations increased during the same period that there was minimal artificial recharge.

\section{Nutrients}

Nutrients such as nitrogen and phosphorus in water are closely related to agricultural activities because of their presence in fertilizers and animal waste. Nutrient-rich water from farms and feedlots can run off into streams or percolate into groundwater. Other sources of nutrients in water include wastewater treatment plants, sewage lagoons, domestic septic tanks (Ziegler and others, 1999, 2001), and the decomposition of organic matter. Nitrate in drinking water can cause adverse effects in humans. The EPA Federal MCL for nitrate is $10 \mathrm{mg} / \mathrm{L}$ as nitrogen, which is the concentration above which methemoglobinemia, or blue baby syndrome, may occur in infants (U.S. Environmental Protection Agency, 2005).

Almost all (more than 99.6 percent) nitrate concentrations in water samples collected at the two surface water monitoring sites on the Little Arkansas River from 1995 through 2012 were less than the MCL of $10 \mathrm{mg} / \mathrm{L}$ for nitrate (table 3). Average nitrate concentration in water samples collected during this period from the Little Arkansas River near Halstead, Kans., and near Sedgwick, Kans., was about $1 \mathrm{mg} / \mathrm{L}$ and ranged from 0.01 to $11.7 \mathrm{mg} / \mathrm{L}$ (table 3 ). The maximum nitrate concentration of $11.7 \mathrm{mg} / \mathrm{L}$ occurred at the site near Sedgwick, Kans. (table 3).

Nitrate concentrations exceeded the MCL in water samples from 15.7 percent of the shallow IWs during 2001-2012 (table 4). Nitrate concentrations exceeded the MCL in the shallow parts of the aquifer in the northern part of the study area between Burrton, Kans., and the Little Arkansas River, and in the southern part of the study area between Sedgwick, Kans., and the Arkansas River during 2006-2012 (fig. 16A). Nearly all nitrate concentrations in deep IWs were less than the MCL of $10 \mathrm{mg} / \mathrm{L}$ during 2001-2012 (table 4) and nitrate concentrations were less than $10 \mathrm{mg} / \mathrm{L}$ throughout the study area during 2006-2012 (fig. 16B). The highest average nitrate concentrations were in the southern part of study area southeast of Bentley, Kans., and are associated with larger effective porosity (fig. 8). Nitrate from sewage lagoons, feedlots, and fertilizer runoff is more likely to increase concentrations in the shallow parts of the aquifer. Reductive conditions (ORP less than $50 \mathrm{mV}$ ) for microbial denitrification, which is the

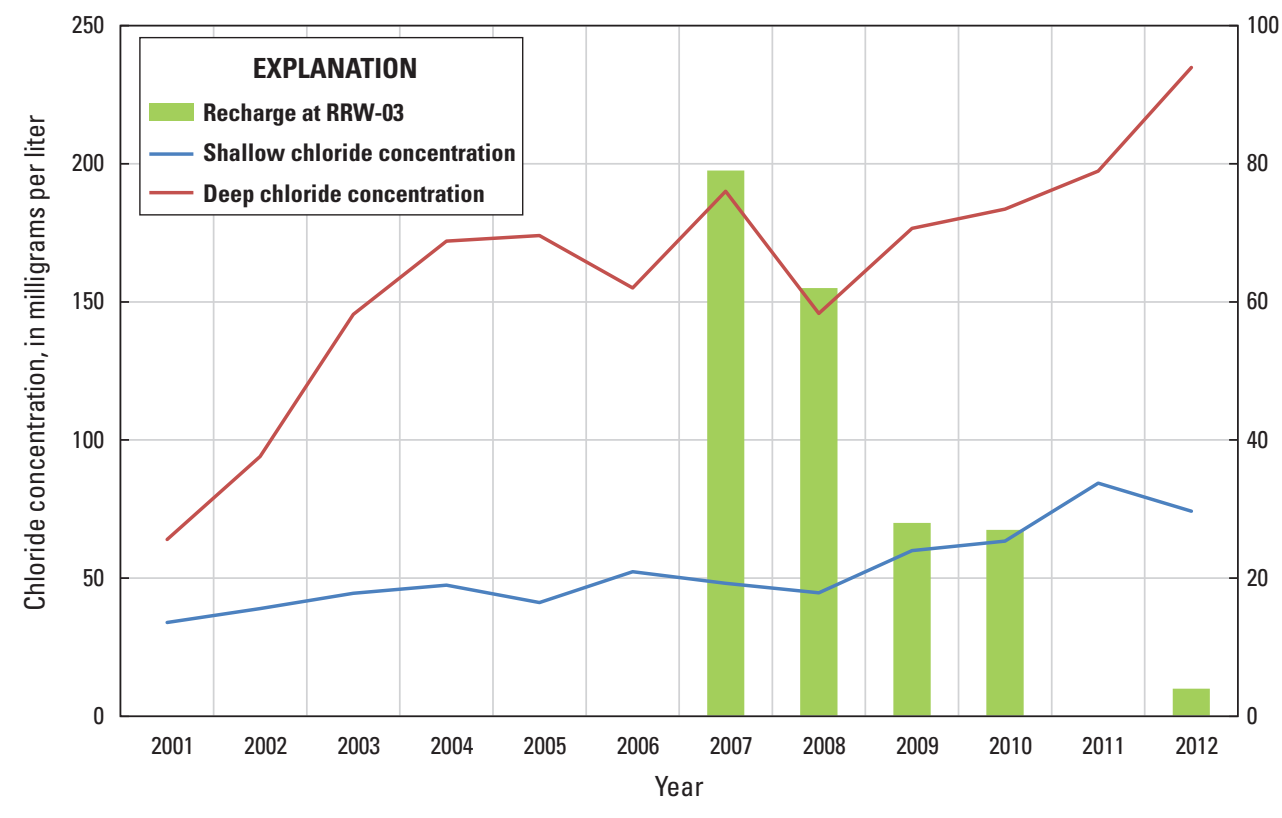

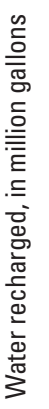

Figure 15. Chloride concentrations in IW-05 (shallow and deep) and Phase I recharge at RRW-03 in the Equus Beds aquifer near Burrton, Kansas, 2001-2012. 


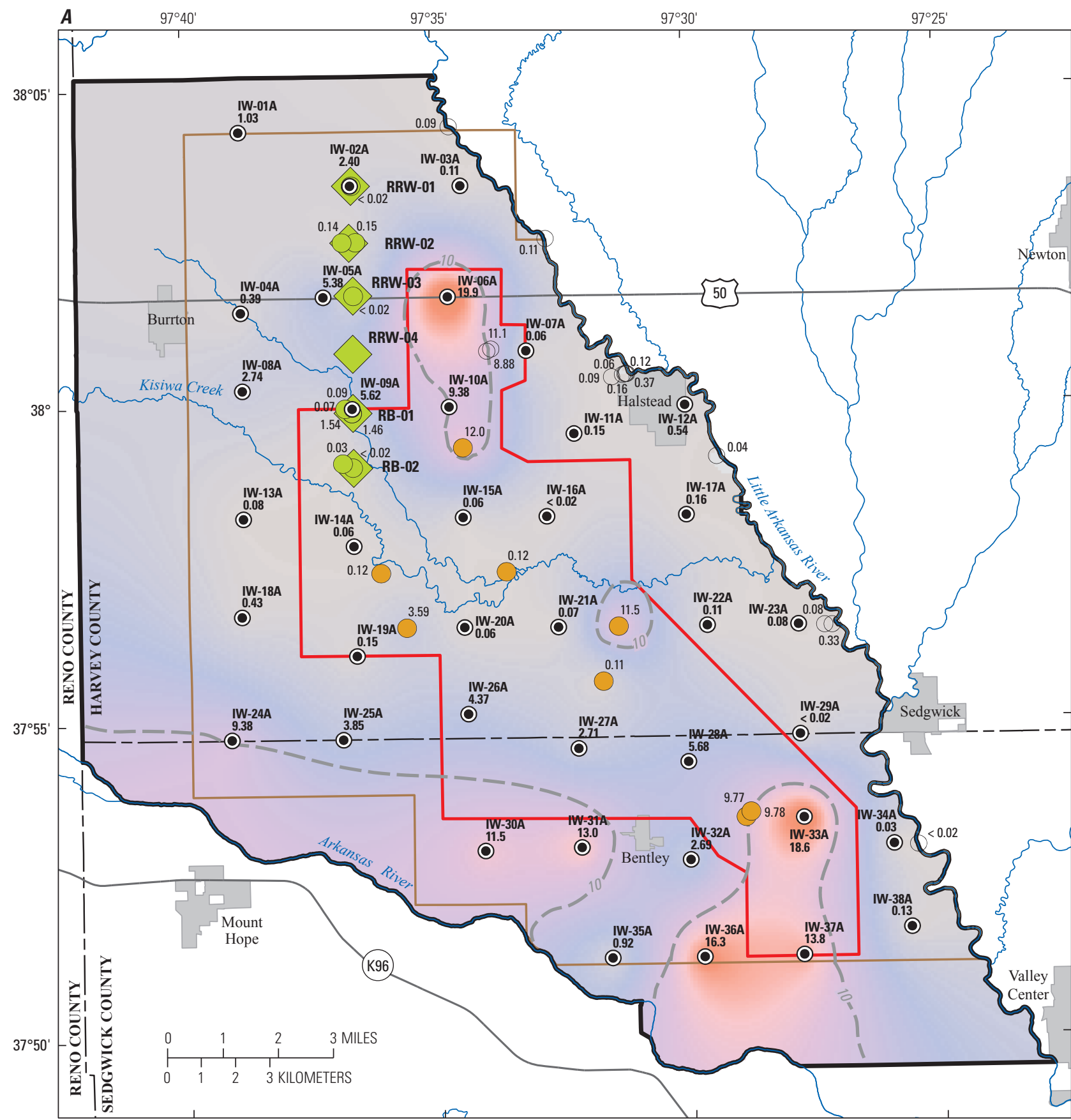

Base from U.S. Geological Survey digital data, 1:24,000, 2012

Universal Transverse Mercator projection, zone 14

Horizontal coordinate information is referenced to the

North American Datum of 1983 (NAD 83)

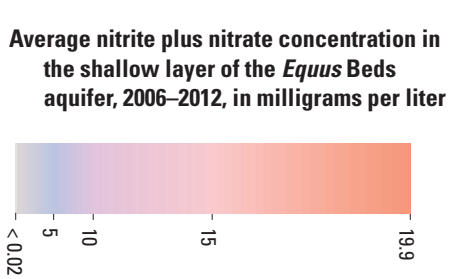

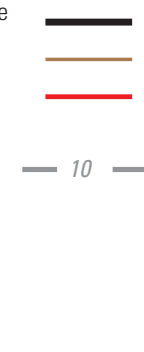

RRW-01
EXPLANATION

Boundary of study area

Boundary of basin storage area

Boundary of the central part of the study area

Average 2006-2012 nitrite plus nitrate concentration in shallow groundwater wells in the approximate location exceed the U.S. Enviornmental Protection Agency's national primary drinking water regulations of 10 milligrams per liter

hase I recharge location and site identifier

\footnotetext{
U.S. Geological Survey data collection site in the shallow layer of the Equus Beds aquifer-Number is average nitrite plus nitrate concentration, in milligrams per liter

$0.14 \bigcirc$ Phase I from 2006 to 2012

$12.0 \bigcirc$ Phase II from 2010 to 2012

IW-01A $\bigcirc$ Index well and site identifier from 2006 to 2012

$0.11 \bigcirc$ Monitoring well from 2006 to 2012
}

Figure 16. Average nitrite plus nitrate concentrations in the study area, 2006-2012, south-central Kansas, in $A$, shallow wells and $B$, deep wells. 


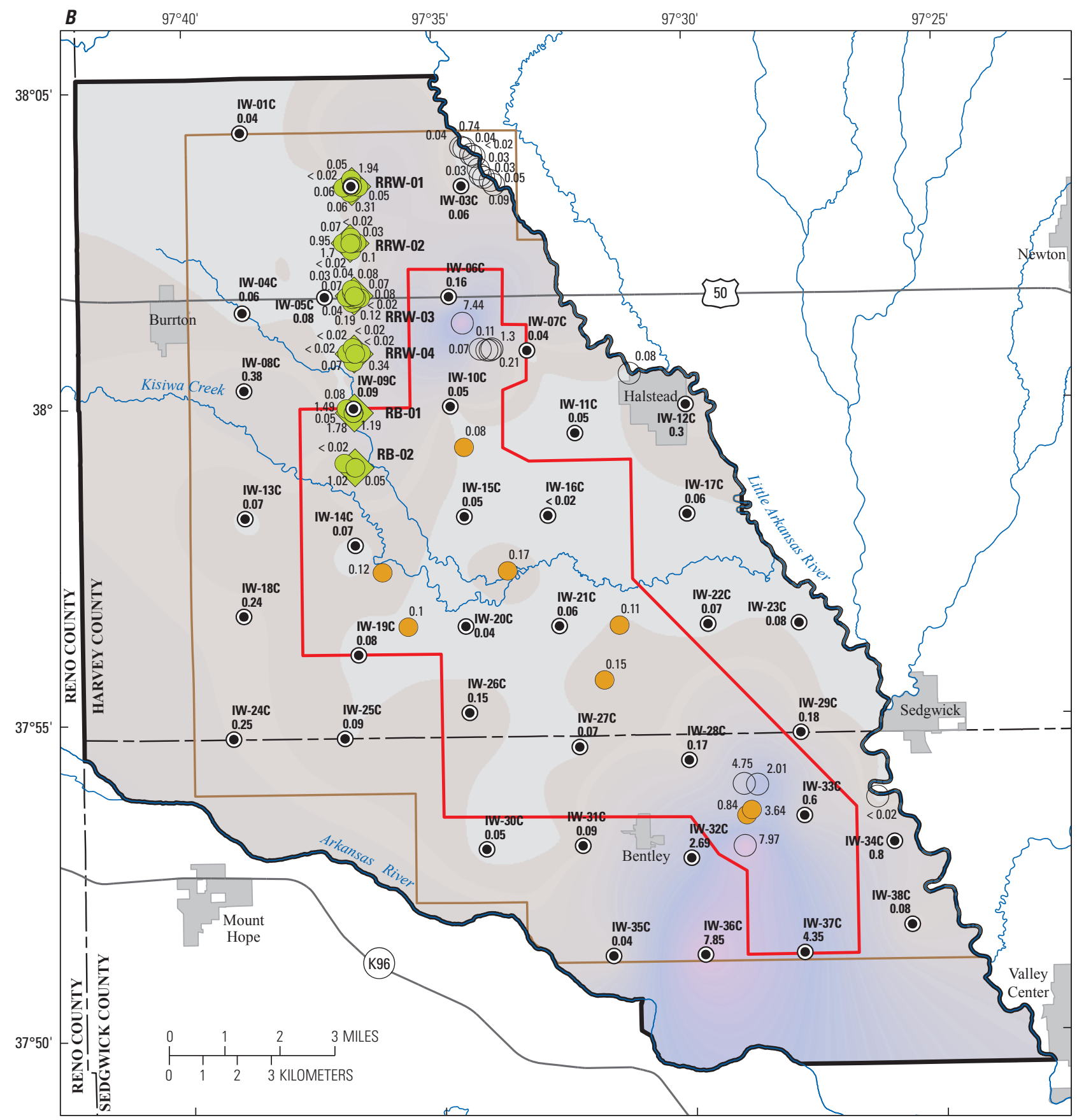

Base from U.S. Geological Survey digital data, 1:24,000, 2012

Universal Transverse Mercator projection, zone 14

Horizontal coordinate information is referenced to the

North American Datum of 1983 (NAD 83)

EXPLANATION

Average nitrite plus nitrate concentration in the deep layer of the Equus Beds aquifer, 2006-2012, in milligrams per liter

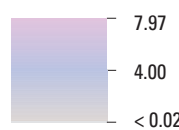

7.97
4.00
$<0.02$

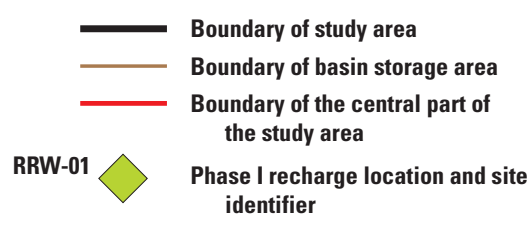

U.S. Geological Survey data collection site in the deep layer of the Equus Beds aquifer-Number is average nitrite plus nitrate concentration, in milligrams per liter

$0.05 \bigcirc$ Phase I from 2006 to 2012

$0.08 \bigcirc$ Phase II from 2010 to 2012

IW-01C $\bigcirc$ Index well and site identifier from 2006 to 2012

$0.11 \bigcirc$ Monitoring well from 2006 to 2012

Figure 16. Average nitrite plus nitrate concentrations in the study area, 2006-2012, south-central Kansas, in $A$, shallow wells and $B$, deep wells.-Continued 
conversion of nitrate to nitrogen gas, are unavailable in the shallow parts of the aquifer (fig. 10A). Locations with larger nitrate concentrations in shallow and deep groundwater likely were at least partly the result of more rapid percolation from agricultural land uses in areas of larger effective porosity (fig. 8) and geochemical controls, especially in deep groundwater. Nitrate concentrations generally were smaller in deeper parts of the aquifer, which is likely a result of more reducing conditions indicated by smaller ORP values (fig. 10). Artificial recharge of oxygenated water could inhibit the denitrification process in previously reductive parts of the aquifer, potentially resulting in increased nitrate concentrations.

\section{Trace Elements}

Dissolved concentrations of trace elements of particular interest in this report include arsenic, iron, and manganese. Arsenic is a carcinogen, whereas iron and manganese precipitates can plug wells, and give water an undesirable taste and color. Infiltration of stream water or treated water into the Equus Beds aquifer by artificial recharge operations could affect dissolved arsenic mobility or could stimulate microbial activity, and cause iron and manganese precipitation from groundwater.

\section{Arsenic}

Although arsenic occurs naturally in clay layers associated with iron sulfide minerals (Hem, 1992), it is a health concern in drinking water because it causes skin damage, affects the circulatory system, and increases cancer risk (U.S. Environmental Protection Agency, 2005). The EPA Federal MCL for arsenic is $10 \mu \mathrm{g} / \mathrm{L}$ (U.S. Environmental Protection Agency, 2009). Water samples collected from the Little Arkansas River near Halstead, Kans., and near Sedgwick, Kans., from 1995 through 2012 had a median and average dissolved arsenic concentration of about $5 \mu \mathrm{g} / \mathrm{L}$, which is one-half the MCL for arsenic of $10 \mu \mathrm{g} / \mathrm{L}$ (table 3 ). Dissolved arsenic concentrations ranged from less than 1 to $15.9 \mu \mathrm{g} / \mathrm{L}$ and exceeded the MCL in about 11 percent of the samples from the Little Arkansas River (table 3).

Christensen and others (2003) developed regression models to compute dissolved arsenic concentrations in the Little Arkansas River based on streamflow. Using the previously developed models, computed dissolved arsenic concentrations as large as $24 \mu \mathrm{g} / \mathrm{L}$ occurred at the Sedgwick surface water monitoring site on the Little Arkansas River from 1999 through 2012. The maximum computed arsenic concentration occurred during the summer of 2012 during substantially decreased streamflow after an extended drought. Generally, larger dissolved arsenic concentrations in stream water occurred during decreased streamflow when base flow to the stream was supplied from groundwater. In the Little Arkansas River near Halstead, Kans., computed dissolved arsenic concentrations exceeded the MCL of $10 \mu \mathrm{g} / \mathrm{L}$ about 19 percent of the time and at the Little Arkansas River near Sedgwick, Kans., about 14 percent of the time (fig. 17).

Dissolved arsenic concentrations exceeded $10 \mu \mathrm{g} / \mathrm{L}$ in water samples from 11.9 percent of the IWs in the shallow parts of the Equus Beds aquifer during 2001-2012 (table 4). Arsenic concentrations in water samples from the shallow parts of the aquifer generally were larger near the Little Arkansas River near Halstead, Kans., and the center of the study area, and, to a lesser extent, around Burrton, Kans., during 2006-2012 (fig. 18A). Average dissolved arsenic concentrations exceeded the MCL near Burrton, Kans., west of Sedgwick, Kans., and in an area extending diagonally to the southwest from near Halstead, Kans. (fig. 18A). One

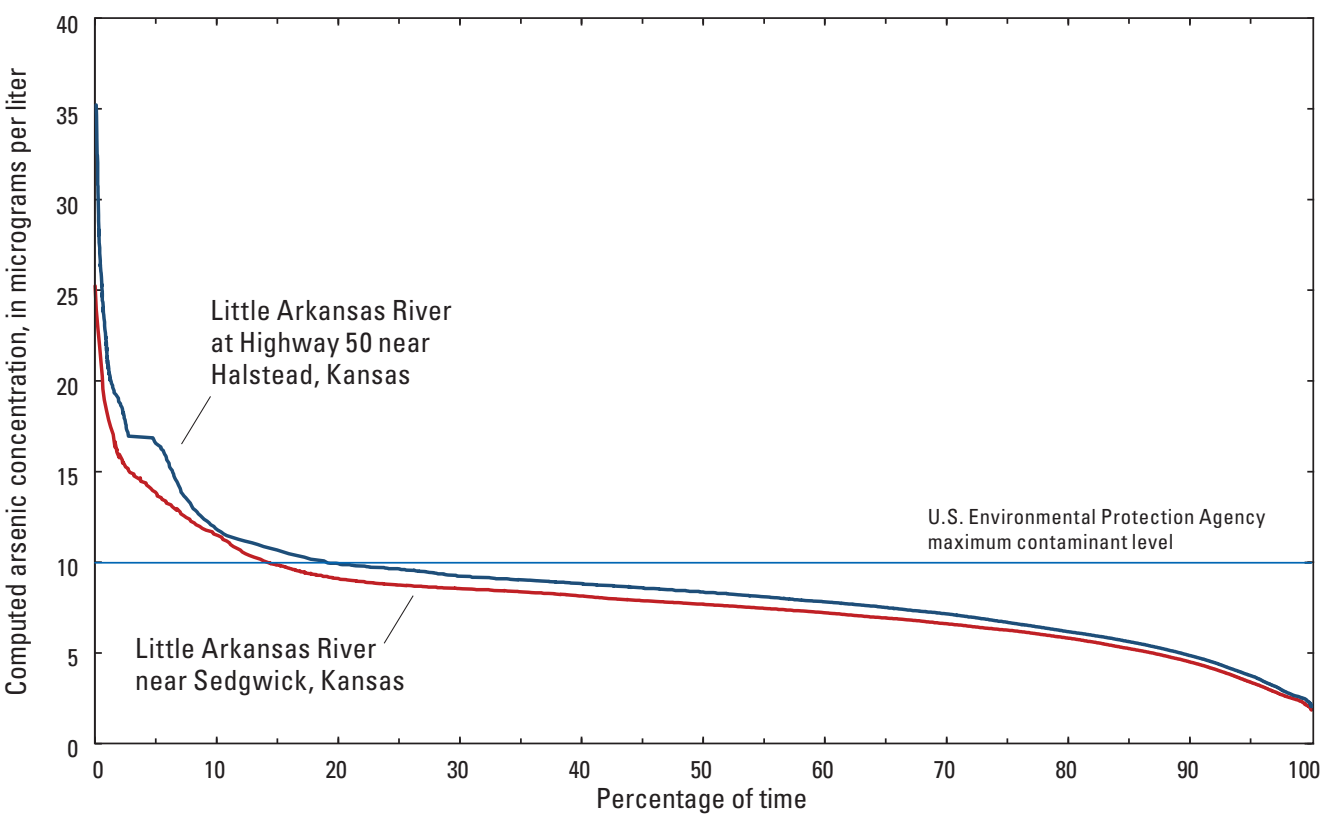

Figure 17. Duration curves of computed dissolved arsenic concentrations, 1999-2012, Little Arkansas River near Halstead and near Sedgwick, Kansas. 


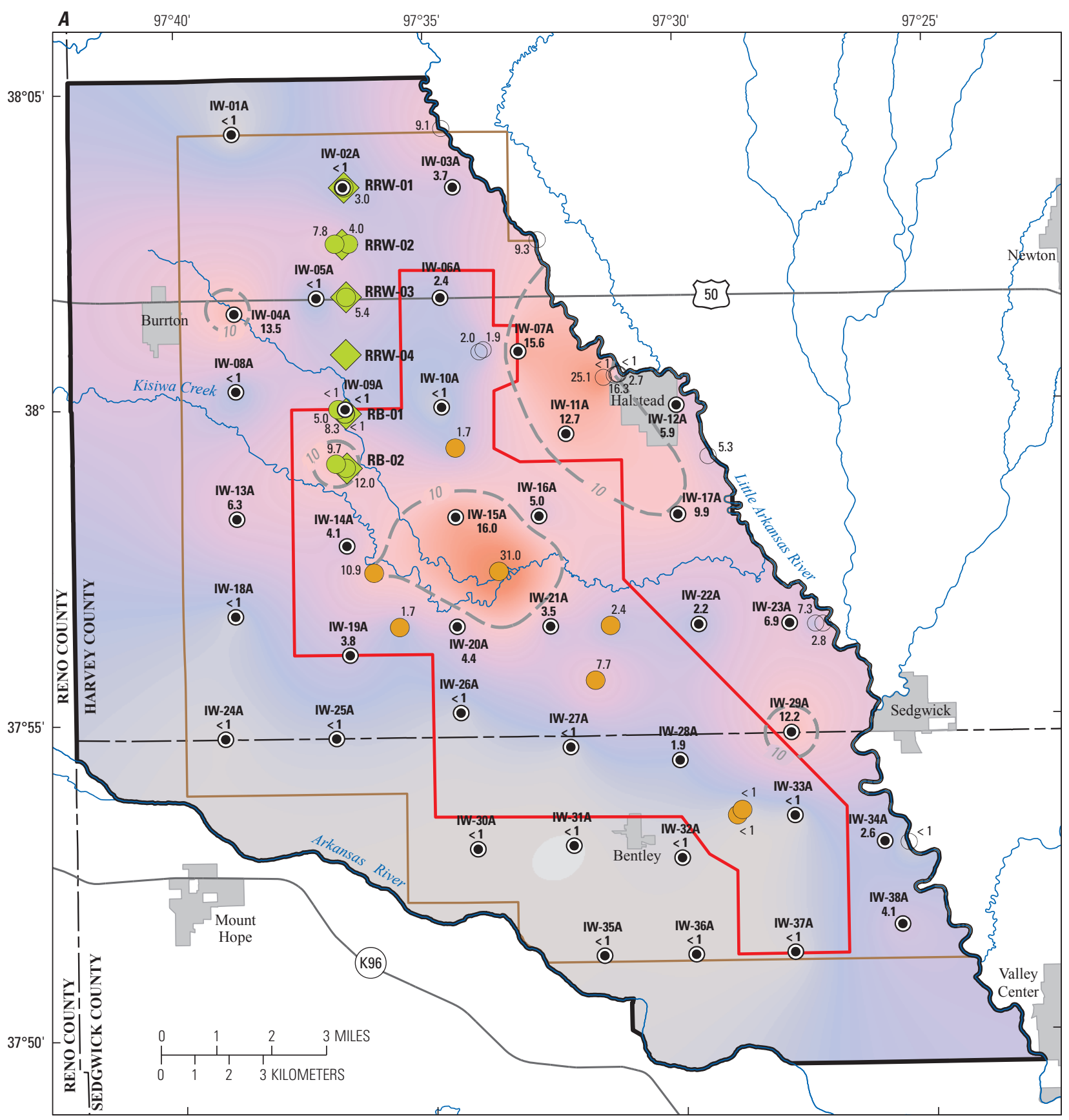

Base from U.S. Geological Survey digital data, 1:24,000, 2012 Universal Transverse Mercator projection, zone 14 Horizontal coordinate information is referenced to the North American Datum of 1983 (NAD 83)

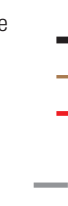

Average arsenic concentration in the shallow layer of the Equus Beds aquifer, 2006-2012, in micrograms per liter

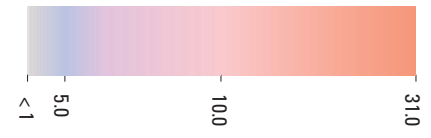

\section{EXPLANATION}

Boundary of study area

Boundary of basin storage area

Boundary of the central part of the study area

- 10 - Average 2006-2012 arsenic concentration in shallow groundwater wells in the approximate location exceed the U.S. Enviornmental Protection Agency's national primary drinking water regulations of 10 micrograms per liter

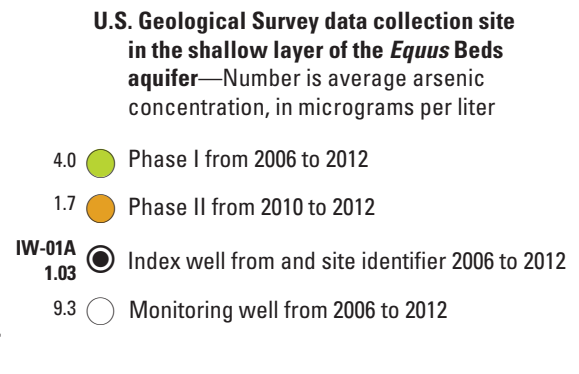

U.S. Geological Survey data collection site in the shallow layer of the Equus Beds averifer-Number is average arsenic

$4.0 \bigcirc$ Phase I from 2006 to 2012

1.7 Phase II from 2010 to 2012

RRW-01

Phase I recharge location and site identifier

Figure 18. Average arsenic concentrations in the study area, 2006-2012, south-central Kansas, in $A$, shallow wells and $B$, deep wells. 


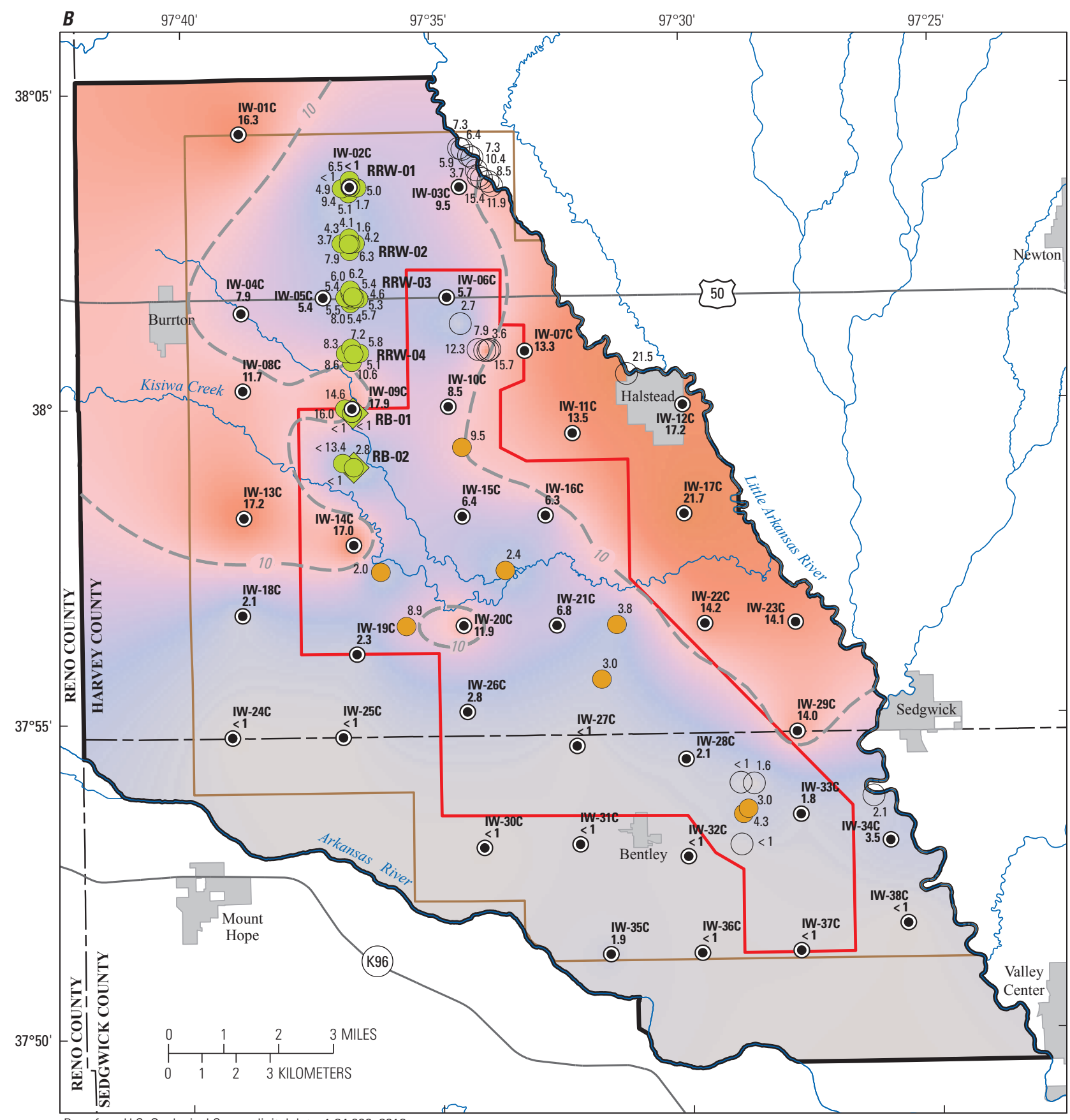

Base from U.S. Geological Survey digital data, 1:24,000, 2012 Universal Transverse Mercator projection, zone 14 Horizontal coordinate information is referenced to the North American Datum of 1983 (NAD 83)

EXPLANATION
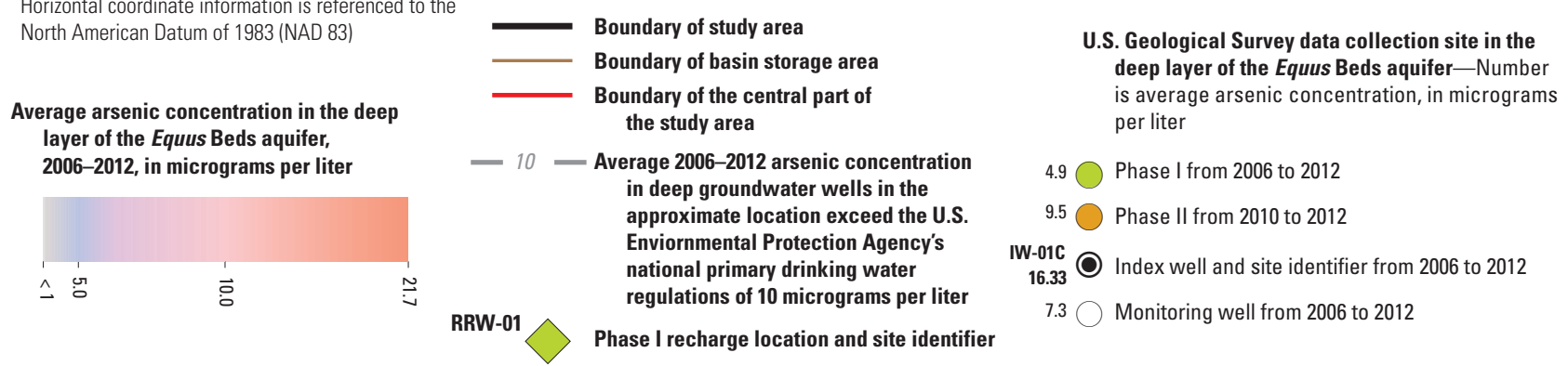

Figure 18. Average arsenic concentrations in the study area, 2006-2012, south-central Kansas, in $A$, shallow wells and $B$, deep wells.-Continued 
ASR Phase II monitoring well (MW-3 shallow; fig. 7A) near Kisiwa Creek in the central part of the study area (fig. 1), had an average arsenic concentration of $31 \mu \mathrm{g} / \mathrm{L}$ (fig. 18A). The central part of the study area corresponds to the areas that had the most water-level recovery since 1993 (Hansen and others, 2014; fig. 5).

Nearly 35 percent of water samples from deep IWs had dissolved arsenic concentrations that exceeded the MCL (table 4). Larger concentrations of arsenic in the deep parts of the aquifer occurred on the west side of the study area near Kisiwa Creek and on the eastern side of the study area along the Little Arkansas River (fig. 1, fig. 18B). Arsenic concentrations were smallest in the southern part of the study area along the Arkansas River. Ziegler and others (2010) identified a moderate to strong negative correlation $\left(\mathrm{R}^{2}=0.63\right)$ between average ORP and average arsenic concentrations for all IWs, indicating larger dissolved arsenic concentrations were most common in areas with reducing conditions. Clay is a natural source of arsenic because arsenic can occur as an impurity in the mineral pyrite (Hem, 1992; Welch and others, 2000), which commonly occurs in clay. In reducing conditions, pyrite can get reduced, which can lead to the dissolution of arsenic resulting in increased concentrations of dissolved arsenic in water. The average ORP values of all IWs sites for 2007-2012 ( $242 \mathrm{mV}$; table 5) has decreased by more than 17 percent relative to 2001-2006 average values (294 mV; table 5), which is of concern because of the potential for increased arsenic mobilization.

Arsenic mobility generally is controlled by adsorption and desorption reactions, and solid-phase precipitation and dissolution reactions (Hem, 1992; Hinkle and Polette, 1999; Smedley and Kinniburgh, 2002; McMahon and Chapelle, 2008). These processes are affected by $\mathrm{pH}$, oxidation/ reduction reactions, and the presence of competing anions, all of which could be altered as a result of artificial recharge activities. Arsenic adsorption to iron-oxide surfaces tends to decrease as $\mathrm{pH}$ increases, resulting in the mobilization of arsenic species; therefore, changes in $\mathrm{pH}$ of groundwater can promote adsorption or desorption of arsenic. Additionally, groundwater $\mathrm{pH}$ often naturally increases with time because of free hydrogen ion consumption during water-bedrock interaction, especially in groundwater systems with long residence times. The oxidation state in which arsenic occurs has an important effect on the mobility and toxicity of arsenic. Arsenate $\left(\mathrm{As}^{5+} ; \mathrm{H}_{2} \mathrm{AsO}_{4}^{-}\right)$is dominant under oxidizing conditions and $\mathrm{pH}$ values between 3 and 7 , and arsenite $\left(\mathrm{As}^{3+} ; \mathrm{HAsO}_{2}\right)$ is dominant under more reducing conditions.

\section{Iron}

Iron in water is derived from rocks and soils. Water containing excessive concentrations of iron is unpleasant to drink because of odor, metallic taste, and rusty color. The EPA Federal SMCL for iron is $300 \mu \mathrm{g} / \mathrm{L}$ (U.S. Environmental Protection Agency, 2009). At concentrations exceeding the
SMCL, iron forms red oxyhydroxide precipitates in water that can stain laundry and plumbing fixtures, and cause corrosion. Iron becomes more soluble in water at low $\mathrm{pH}$ and low ORP values. Bacterial activity also may affect iron concentrations (Hem, 1992) and can be of particular concern in artificial recharge operations. The addition of oxygenated water could create favorable conditions for increased bacterial activity. In turn, increased biological activity can produce a biofilm that can clog well screens and decrease injection well efficiency (Schmidt and others, 2007).

Water samples collected from the Little Arkansas River near Sedgwick, Kans., had a median dissolved iron concentration of $16.1 \mu \mathrm{g} / \mathrm{L}$, which is substantially smaller than the SMCL (table 3), whereas water samples from the Little Arkansas River near Halstead, Kans., had a median of $9.7 \mu \mathrm{g} / \mathrm{L}$ (table 3). Samples with dissolved iron concentrations that exceeded the SMCL were collected from both surface water monitoring sites on the Little Arkansas River, but were exceeded in 8.0 percent of samples near Sedgwick, Kans., and 2.8 percent of samples near Halstead, Kans. (table 3). Overall, dissolved iron concentrations at the two Little Arkansas River sites exceeded the SMCL in about 5 percent of the samples. Larger concentrations of iron likely were caused by colloids that passed through the $0.45-\mu \mathrm{m}$ filters during sample processing when sediment concentrations were larger.

Dissolved iron concentrations exceeded the SMCL from 37.2 and 44.6 percent of the samples from the IWs in the shallow and deep parts of the aquifer during 2001-2012, respectively (table 4). Iron concentrations were as large as 40,700 $\mu \mathrm{g} / \mathrm{L}$ in the shallow part of the aquifer at well IW-20A and as large as $17,900 \mu \mathrm{g} / \mathrm{L}$ in the deep part of the aquifer. Dissolved concentrations of iron that exceeded $300 \mu \mathrm{g} / \mathrm{L}$ in the shallow and deep parts of the aquifer occurred mostly in the central and northwestern parts of the study area, and along the Little Arkansas River (fig. 19A; fig. 19B).

Iron in the Equus Beds aquifer most likely occurs naturally from the oxidation of pyrite $\left(\mathrm{FeS}_{2}\right)$, which occurs in clay in the aquifer. Very large dissolved concentrations of iron (greater than 3,000 $\mu \mathrm{g} / \mathrm{L}$ ) in the shallow parts of the aquifer generally correspond with areas of larger water-level declines and subsequent recovery (fig. 4; fig. 19A). These larger concentrations likely were caused by oxidation of the aquifer material during the drawdown period. After an increase in water levels, ferric oxyhydroxides that formed during the period of dewatering were likely reduced increasing dissolved iron in groundwater. These areas also had larger sulfate concentrations, which also indicated that pyrite oxidation occurred during the period of dewatering (fig. 11A). Previously published data by Hathaway and others (1981) documented dissolved iron concentrations larger than 1,500 $\mu \mathrm{g} / \mathrm{L}$ in groundwater near Burrton, Kans., and Kisiwa Creek, and concentrations less than $50 \mu \mathrm{g} / \mathrm{L}$ occurred near the Arkansas River. Based on the data collected by Hathaway and others (1981) and this report, iron concentrations have not changed substantially in these areas during the past 30 years. 


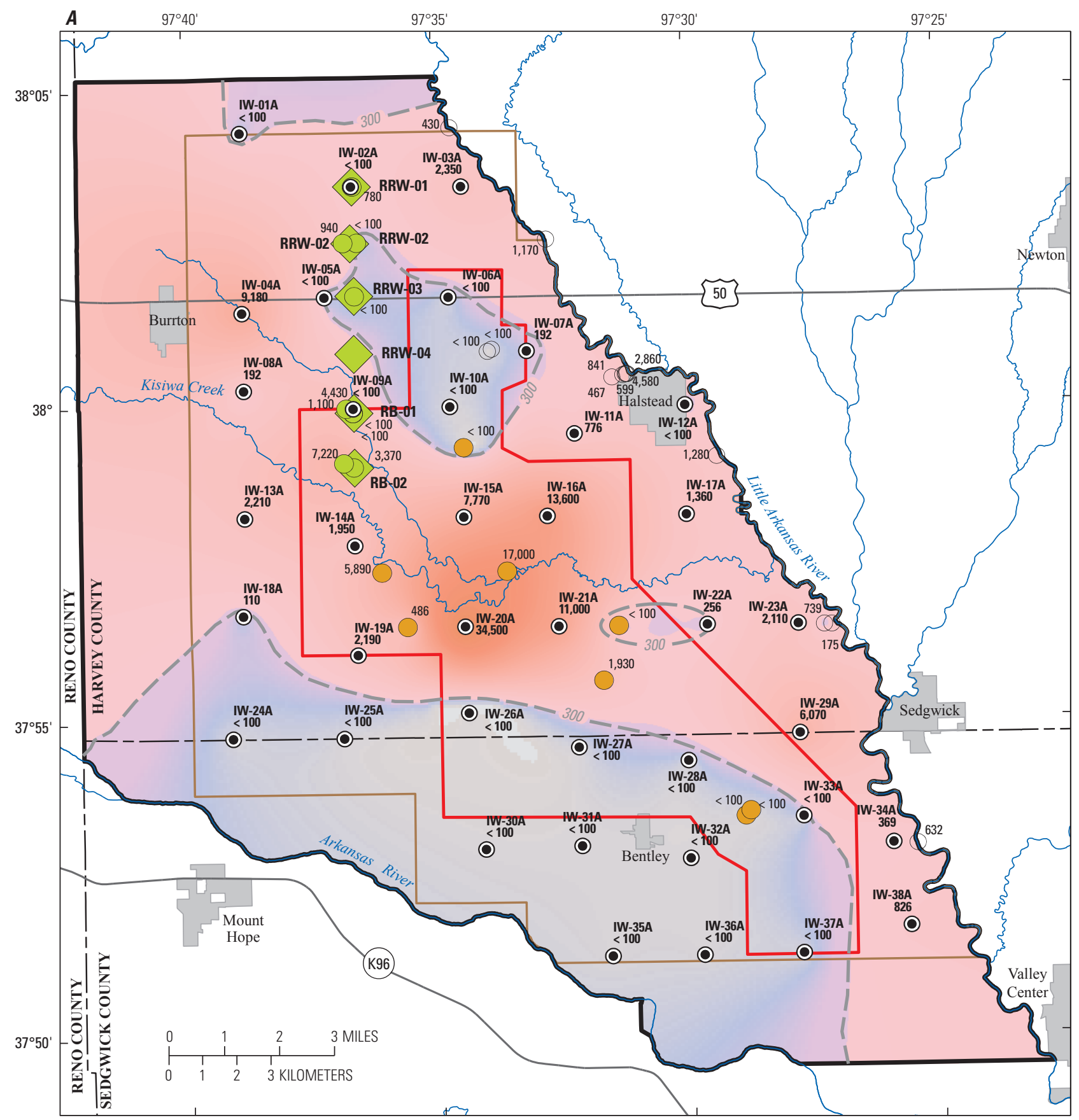

Base from U.S. Geological Survey digital data, 1:24,000, 2012

Universal Transverse Mercator projection, zone 14

Horizontal coordinate information is referenced to the

North American Datum of 1983 (NAD 83)

EXPLANATION

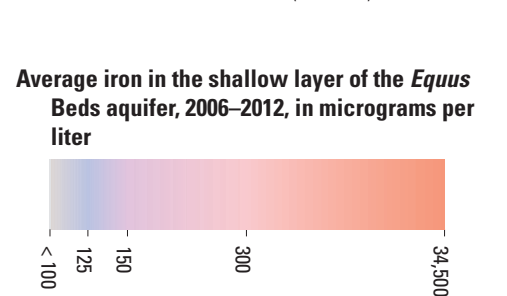

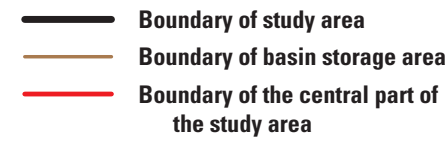

- 300 - Average 2006-2012 iron concentration in shallow groundwater wells in the approximate location exceed the U.S Enviornmental Protection Agency's national secondary drinking water

Phase I recharge location and site identifier regulations of $\mathbf{3 0 0}$ micrograms per liter

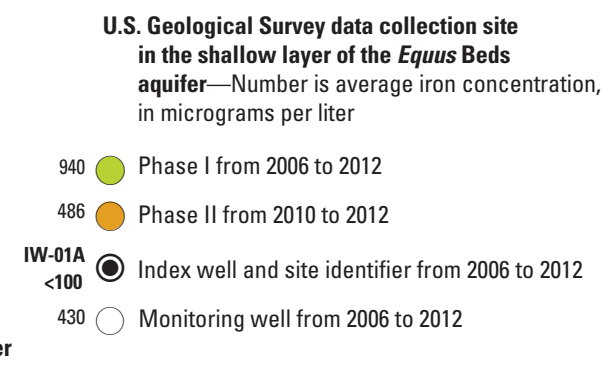

U.S. Geological Survey data collection site in the shallow layer of the Equus Beds aquifer-Number is average iron concentration, in micrograms per liter

RRW-01

Figure 19. Average dissolved iron concentrations in the study area, 2006-2012, south-central Kansas, in $A$, shallow wells and $B$, deep wells. 


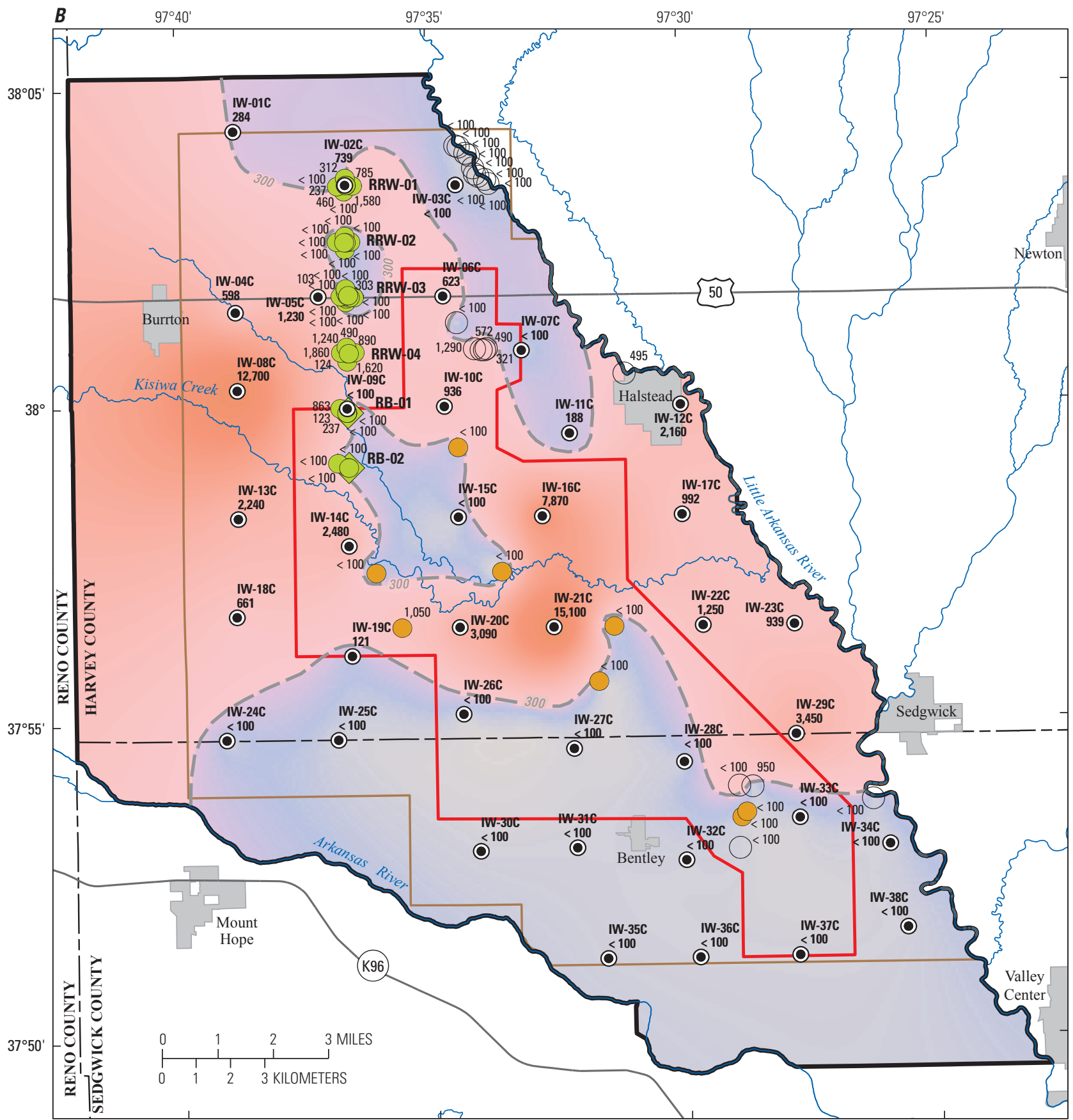

Base from U.S. Geological Survey digital data, 1:24,000, 2012

Universal Transverse Mercator projection, zone 14

Horizontal coordinate information is referenced to the

North American Datum of 1983 (NAD 83)

EXPLANATION

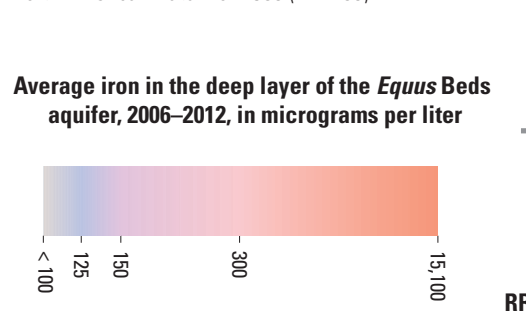

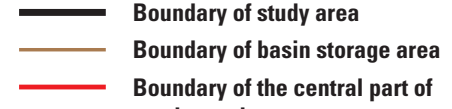
the study area

- 300 - Average 2006-2012 iron concentration in deep groundwater wells in the approximate location exceed the U.S. Enviornmental Protection Agency's national secondary drinking water regulations of $\mathbf{3 0 0}$ micrograms per liter

Phase I recharge location and site identifier
U.S. Geological Survey data collection site in the deep layer of the Equus Beds aquifer-Number is average iron concentration, in micrograms per liter

$237 \bigcirc$ Phase I from 2006 to 2012

$<100 \bigcirc$ Phase II from 2010 to 2012

IW-01C

284 Index well and site identifier from 2006 to 2012

$<100 \bigcirc$ Monitoring well from 2006 to 2012

Figure 19. Average dissolved iron concentrations in the study area, 2006-2012, south-central Kansas, in $A$, shallow wells and $B$, deep wells.-Continued 


\section{Manganese}

Manganese is another trace element that is commonly analyzed in water because of its tendency to deposit black oxide stains. Like iron, manganese originates from rocks and soil, but it is much less abundant than iron (Hem, 1992). The EPA Federal SMCL for manganese is $50 \mu \mathrm{g} / \mathrm{L}$ (U.S. Environmental Protection Agency, 2009). At concentrations larger than the SMCL, consumers may notice a bitter metallic taste, a black to brown color, and black staining on plumbing fixtures (U.S. Environmental Protection Agency, 2005).

Dissolved manganese in water samples collected during 1995 through 2012 at the two surface water monitoring sites on the Little Arkansas River near Halstead, Kans., and near Sedgwick, Kans., ranged from less than 1 to $1,140 \mu \mathrm{g} / \mathrm{L}$, and had median concentrations of $70.1 \mu \mathrm{g} / \mathrm{L}$ and $36.1 \mu \mathrm{g} / \mathrm{L}$, respectively, which exceeded and were near the SMCL (table 3). Manganese concentrations exceeded the SMCL in 54.9 percent of water samples collected from the Little Arkansas River near Halstead, Kans., and 45.6 percent near Sedgwick, Kans. (table 3).

Dissolved manganese concentrations exceeded the SMCL in water samples from 54.6 percent of the IWs in the shallow parts of the Equus Beds aquifer in the study area, and median concentrations were $82.0 \mu \mathrm{g} / \mathrm{L}$ during 2001-2012 (table 4). In shallow parts of the aquifer, almost all of the central and northern parts of study area had average dissolved manganese concentrations that exceeded $50 \mu \mathrm{g} / \mathrm{L}$ during 2006-2012 (fig. 20A). Average dissolved manganese concentrations larger than $500 \mu \mathrm{g} / \mathrm{L}$ were detected near Burrton, Kans., in a large area about 5 mi southwest of Halstead, Kans., and areas near the Little Arkansas River (fig. 20A).

Dissolved manganese concentrations exceeded the SMCL in water samples from 91.8 percent of the IWs in the deep parts of the aquifer (table 4). A dissolved manganese concentration of $1,480 \mu \mathrm{g} / \mathrm{L}$ was the largest from the deep parts of the aquifer. Most of the study area had average dissolved manganese concentrations that exceeded $50 \mu \mathrm{g} / \mathrm{L}$ in water from deep wells (fig. 20B). Average dissolved manganese concentrations exceeded $500 \mu \mathrm{g} / \mathrm{L}$ in water from the deep parts of the aquifer in a large area in the center of the study area, near Burrton, Kans., near Sedgwick Kans., and near Halstead, Kans. (fig. 20B).

\section{Organic Compounds}

Many of the organic compounds detected in surface water and groundwater in the study area are chemicals used in agricultural pesticides and herbicides. These compounds enter streams or slowly infiltrate into the aquifer from the application on fields, or through irrigation return flow and surface runoff. Atrazine is an herbicide commonly used on corn and sorghum, which are crops commonly grown in the study area. Atrazine can cause cardiovascular system or reproductive problems in humans (U.S. Environmental Protection Agency, 2009). The EPA Federal MCL in drinking water for atrazine is
$3.0 \mu \mathrm{g} / \mathrm{L}$ as an annual average (U.S. Environmental Protection Agency, 2009).

Ziegler and others (1999) identified that atrazine made up 81 percent of the triazine compound concentrations detected in Little Arkansas River samples by using the enzyme-linked immunosorbent assay (ELISA) method. Therefore, dissolved triazine compounds detected by ELISA will be referred to as atrazine concentrations. Atrazine was detected in about 98 percent of the surface water samples collected for this study and exceeded $3.0 \mu \mathrm{g} / \mathrm{L}$ in about 33 percent of the samples analyzed for triazine herbicides (table 3 ). Average rather than median concentrations of atrazine are discussed in this report to facilitate a direct comparison of measured and computed atrazine concentrations to the MCL, which is defined as an annual average.

The summary of concentrations of atrazine in surface water samples collected from 1995 through 2012 at the two monitoring sites on the Little Arkansas River had an average concentration of $3.4 \mu \mathrm{g} / \mathrm{L}$, which exceeded the MCL (table 3). The average atrazine concentrations were $2.4 \mu \mathrm{g} / \mathrm{L}$ near Halstead, Kans., and $3.7 \mu \mathrm{g} / \mathrm{L}$ near Sedgwick, Kans. (table 3). Atrazine concentrations larger than the MCL of $3.0 \mu \mathrm{g} / \mathrm{L}$ generally occur in the Little Arkansas River during late spring to early fall. Regression models for computing concentrations of atrazine in the Little Arkansas River were previously developed by Christensen and others (2003) using specific conductance measurements in the stream and day of year. Duration curves of computed atrazine concentrations exceeded the MCL of $3.0 \mu \mathrm{g} / \mathrm{L}$ about 24 percent of the time from 1999 through 2012 in the Little Arkansas River near Halstead, Kans., and 28 percent of the time near Sedgwick, Kans. (fig. 21).

Alachlor, which is an herbicide used to control weeds in soybeans, was the only organic compound other than atrazine that was frequently detected (about 61 percent) in surface water samples. Only 2.4 percent of the samples were above levels exceeding the EPA Federal drinking-water criterion of $2 \mu \mathrm{g} / \mathrm{L}$ for alachlor (table 3; U.S. Environmental Protection Agency, 2009). Dissolved concentrations of alachlor in the Little Arkansas River near Halstead, Kans., were as large as $28 \mu \mathrm{g} / \mathrm{L}$ (table 3 ). Alachlor was infrequently detected in groundwater samples, and of the samples with detections, none approached the MCL (table 4). The only other organic compound with a Federal MCL that was detected more than 5 percent of the time in groundwater was bis(2-ethylhexyl) phthalate, and of the detections the average $(4.8 \mu \mathrm{g} / \mathrm{L})$ was near the MCL of $6 \mu \mathrm{g} / \mathrm{L}$ (available online at: http://ks.water. usgs.gov/equus-water-quality, June 2014). Bis(2-ethylhexyl) phthalate is a plasticizer used in polyvinyl chloride ([PVC]; U.S. Environmental Protection Agency, 2009), which indicates the detections are likely from the PVC well material.

The relation between ELISA triazine compound analysis and atrazine concentrations is not defined in groundwater in the study area (Ziegler and others, 2010), therefore, groundwater atrazine concentrations discussed hereafter were determined by gas chromatography-mass spectrometry ( $\mathrm{GC}-$ MS). In groundwater, the percentage of samples with atrazine 


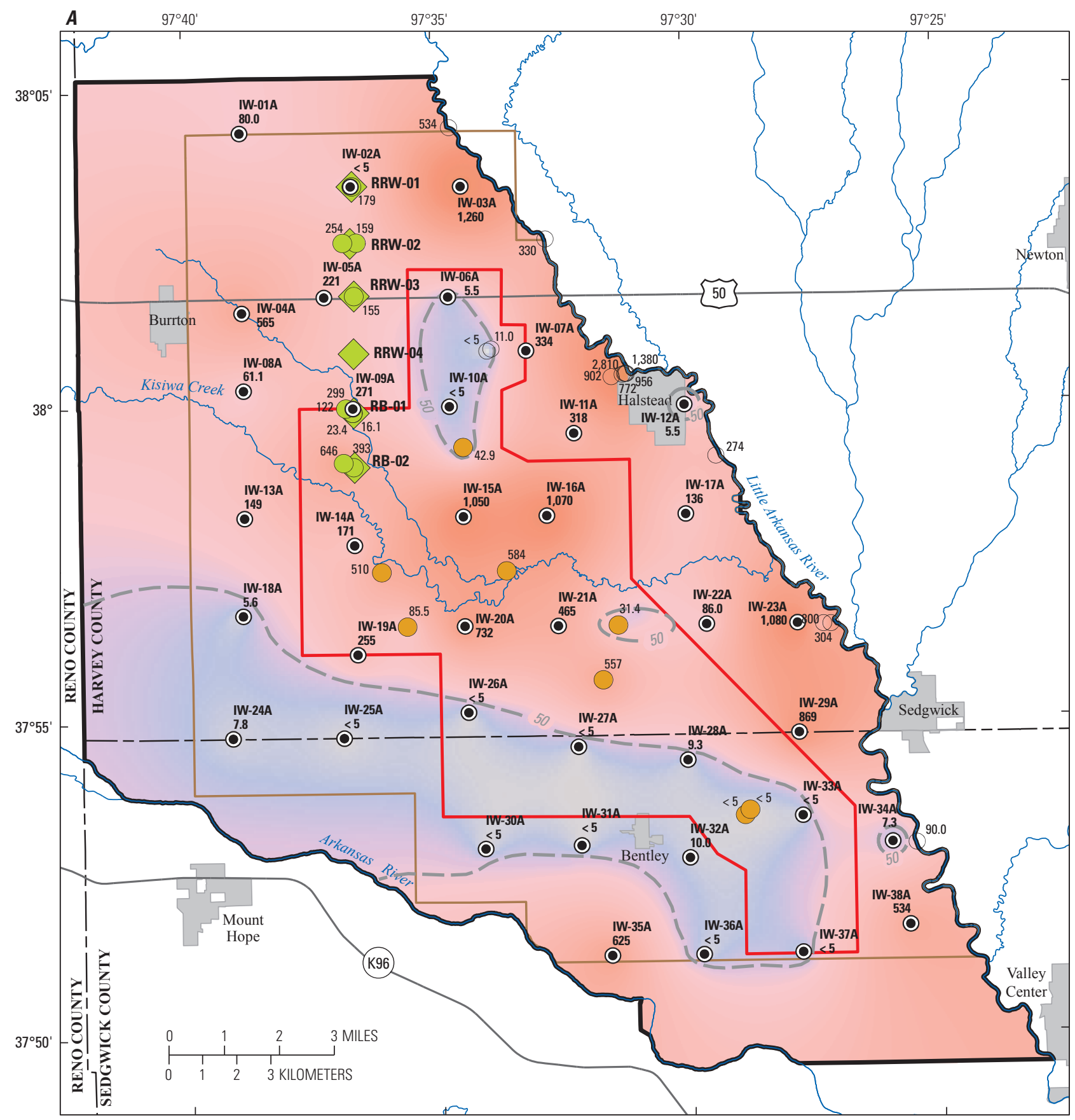

Base from U.S. Geological Survey digital data, 1:24,000, 2012 Universal Transverse Mercator projection, zone 14 Horizontal coordinate information is referenced to the North American Datum of 1983 (NAD 83)

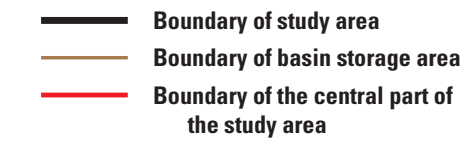

- 50 - Average 2006-2012 manganese concentration in shallow groundwater wells in the approximate location exceed the U.S. Enviornmental Protection Agency's national secondary drinking water regulations of 50 micrograms per liter
Average manganese in the shallow layer of the Equus Beds aquifer, 2006-2012, in micrograms per liter

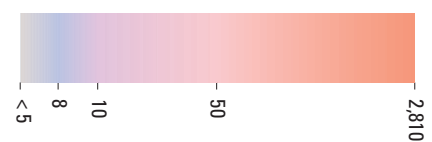

Phase I recharge location and site identifier

U.S. Geological Survey data collection site in the shallow layer of the Equus Beds aquifer-Number is average iron concentration, in micrograms per liter

$179 \bigcirc$ Phase I from 2006 to 2012

42.9 Phase II from 2010 to 2012

80.0 $\bigcirc$ Index well and site identifier from 2006 to 2012

$534 \bigcirc$ Monitoring well from 2006 to 2012

RRW-01

Figure 20. Average dissolved manganese concentrations in the study area, 2006-2012, south-central Kansas, in $A$, shallow wells and $B$, deep wells. 


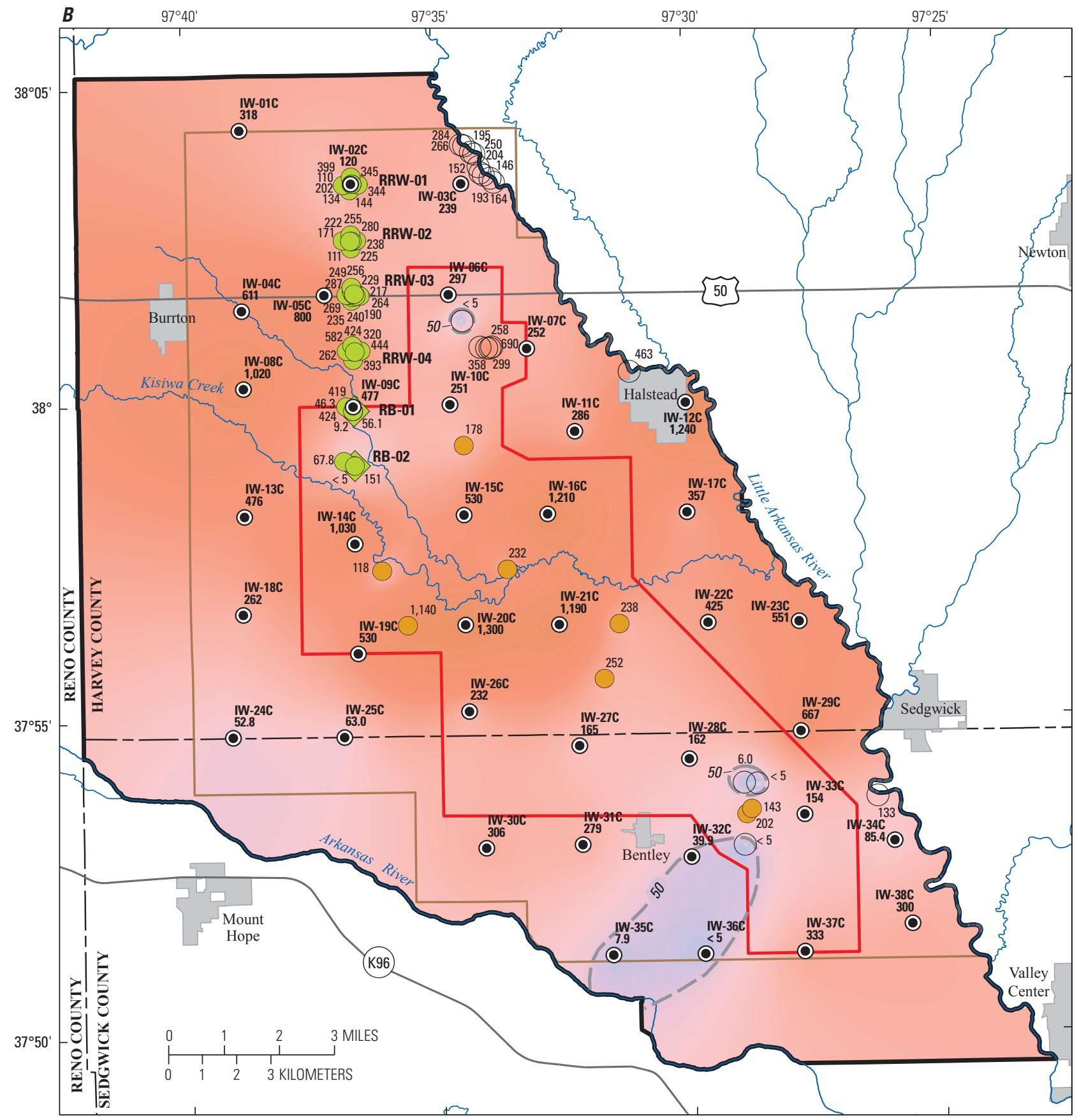

Base from U.S. Geological Survey digital data, 1:24,000, 2012 Universal Transverse Mercator projection, zone 14

Horizontal coordinate information is referenced to the North American Datum of 1983 (NAD 83)

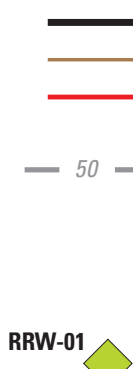

EXPLANATION

Average manganese in the deep layer of the Equus Beds aquifer, 2006-2012, in micrograms per liter

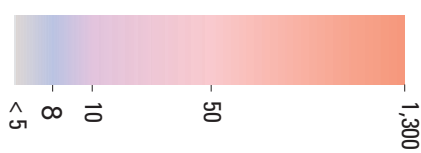

Boundary of study area

Boundary of basin storage area

Boundary of the central part of the study area

Average 2006-2012 manganese concentration in deep groundwater wells in the approximate location exceed the U.S. Enviornmental Protection Agency's national secondary drinking water regulations of $\mathbf{5 0}$ micrograms per liter

Phase I recharge location and site identifier

U.S. Geological Survey data collection site in the deep layer of the Equus Beds aquifer-Number is average iron concentration, in micrograms per liter

$110 \bigcirc$ Phase I from 2006 to 2012

$178 \bigcirc$ Phase II from 2010 to 2012

IW-01C $\bigcirc$ Index well and site identifier from 2006 to 2012

$284 \bigcirc$ Monitoring well from 2006 to 2012

Figure 20. Average dissolved manganese concentrations in the study area, 2006-2012, south-central Kansas, in $A$, shallow wells and $B$, deep wells.-Continued 


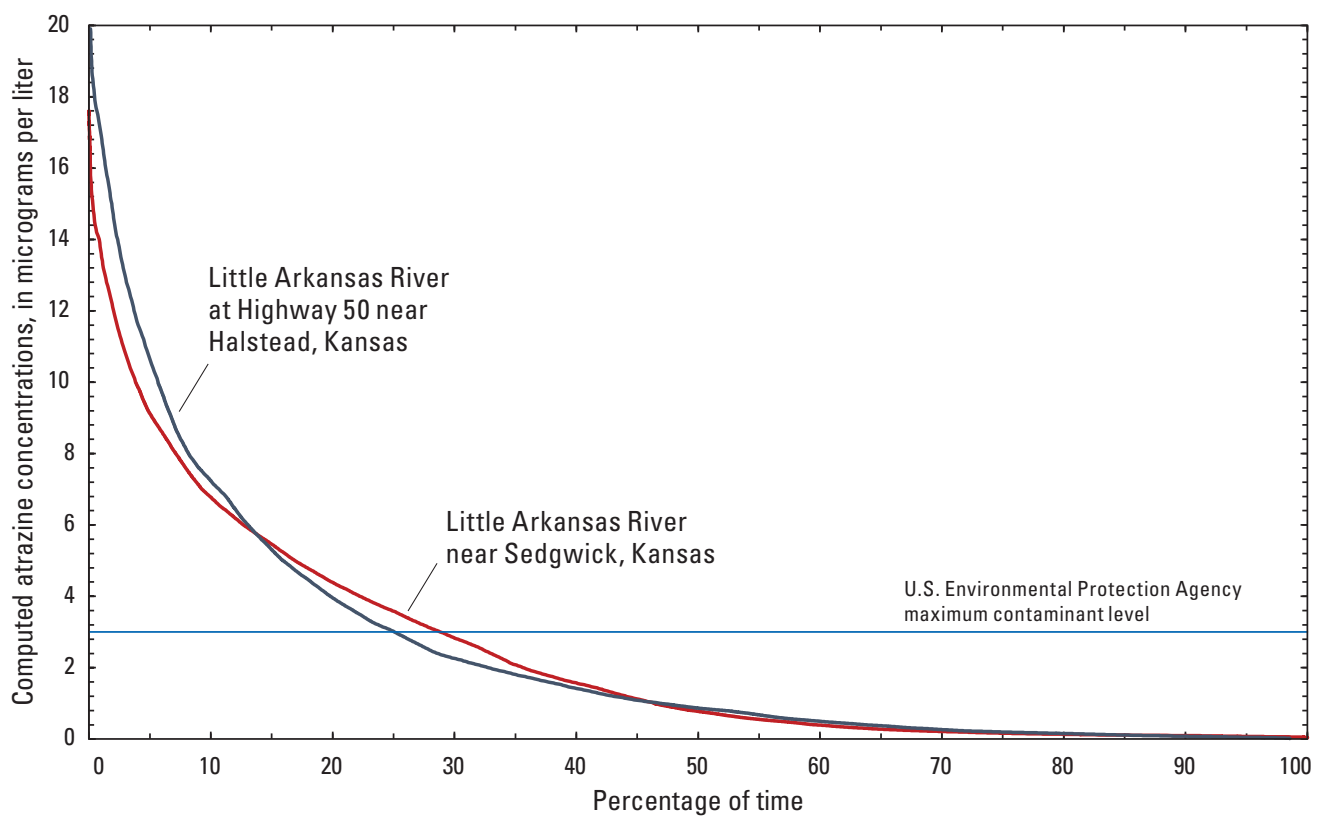

Figure 21. Duration curves of computed atrazine concentrations, 1999-2012, Little Arkansas River near Halstead and near Sedgwick, Kansas. detections ranged from 26.0 percent in deep IWs to about 57.0 percent in water from shallow IWs during 2001-2012, which indicates infiltration from field applications (table 4). Average atrazine concentrations were less than $0.1 \mu \mathrm{g} / \mathrm{L}$ in the shallow and deep IWs, and no samples exceeded the Federal MCL (table 4). Similar to the general groundwater concentrations of atrazine, ASR Phase I monitoring wells resulted in atrazine detections in 50.0 percent of samples from shallow wells and 33.6 percent of samples from deep wells (table 4). The largest atrazine concentration in the IW network during 2001-2012 was $1.4 \mu \mathrm{g} / \mathrm{L}$ in water from IW-04A, which is near the North Branch Kisiwa Creek (fig. 7A; fig. 1).

\section{Bacterial and Viral Indicators}

Measuring the concentrations or densities of bacterial indicators and viruses in water is challenging because these organisms depend on specific conditions for growth. Additionally, the presence of bacteria and viruses in water is affected by runoff into waterways; therefore, sampling must quantify concentrations during storm runoff to describe the variability in surface water.

To indicate the presence of disease-causing organisms in water, a bacterial indicator such as coliform is measured. Fecal coliform and E. coli are two types of coliform indicator bacteria that come only from the intestines and waste material of homeothermic animals. E. coli are a specific type of fecal coliform. They are carried into water from septic systems, sewer pipes, wastewater treatment plants, farms, and yards. The presence of fecal coliform and E. coli indicates that water may be contaminated with human or animal wastes, and may indicate that other harmful bacteria or viruses are present (Dufour and others, 1981; Dufour, 1984). These bacteria indicate the potential for pathogens that may cause diarrhea, nausea, headaches, and abdominal cramps, and may pose a special health risk for infants, young children, and people with compromised immune systems (U.S. Environmental Protection Agency, 2009).

\section{Total Coliform}

The EPA Federal MCL in drinking water for total coliform bacteria is that no more than 5 percent of samples test positive during 1 month for water systems that collect at least 40 routine samples per month (U.S. Environmental Protection Agency, 2009). If fewer than 40 samples are collected per month, only 1 sample can test positive for total coliform (U.S. Environmental Protection Agency, 2009). The EPA Federal maximum contaminant level goal (MCLG) in drinking water for total coliform bacteria is 0 colonies per 100 milliliters (col/100 mL).

The median total coliform density of $1,700 \mathrm{col} / 100 \mathrm{~mL}$ for water samples collected from 1995 through 2012 at the Little Arkansas River near Sedgwick, Kans. (table 3), was substantially larger than the MCLG for drinking water for total coliform of $0 \mathrm{col} / 100 \mathrm{~mL}$. Similarly, the median total coliform density at the Little Arkansas River at Highway 50 near Halstead, Kans. was 1,350 col/100 mL (table 3). About 95 percent of the samples collected from the two sites on the Little Arkansas River had total coliform detections. Coliform detections in water samples collected from the Little Arkansas River during this period were as large as 2,000,000 col/100 $\mathrm{mL}$ near Halstead, Kans., and as large as 9,000,000 col/100 $\mathrm{mL}$ near Sedgwick, Kans. (table 3). Large detections in surface water likely resulted from municipal wastewater discharge or runoff from livestock-producing areas. These large bacterial indicator densities are typical in central and eastern Kansas streams, especially during runoff conditions (Kansas Department of Health and Environment, 2006a and 2006b). 
Total coliform densities in groundwater were substantially less than in samples from the Little Arkansas River (tables 3 and 4). Total coliform detections exceeded the EPA Federal MCLG of 0 colonies in water samples from 24.7 percent of the shallow IWs and in 12.4 percent of the deep IWs in the Equus Beds aquifer during 2001-2012 (table 4). Many of these detections were in the first samples collected from the wells after they were developed, indicating that at least some of these detections may be related to drilling. Almost all wells sampled for this study had at least one sample with a total coliform detection; however, the median densities for most of these wells were less than $1 \mathrm{col} / 100 \mathrm{~mL}$ (table 4). No areal distribution pattern was identified for total coliform detections in groundwater samples from the study area.

\section{Fecal Coliform}

No EPA Federal drinking-water criterion for fecal coliform bacteria has been established for drinking water; however, the State of Kansas established recreational-use guidelines for water in Kansas streams of $200 \mathrm{col} / 100 \mathrm{~mL}$ for primary contact (swimming) during April 1 through October 31 of each year, and 2,000 col/100 mL for primary contact during the rest of the year and for secondary contact (boating or wading; Kansas Department of Health and Environment, 2001).

During 1995 through 2012, the median fecal coliform densities in water samples collected from April through October were $884 \mathrm{col} / 100 \mathrm{~mL}$ for the Little Arkansas River site near Halstead, Kans., and $900 \mathrm{col} / 100 \mathrm{~mL}$ for the site near Sedgwick, Kans., while the median densities from November through March were $120 \mathrm{col} / 100 \mathrm{~mL}$ for both sites (table 3).
About 78 percent of the samples collected from the Little Arkansas River for April through October exceeded the criterion, and about 14 percent of the samples collected exceeded the criterion during November-March during 1995 through 2012 (table 3).

Regression models developed by Rasmussen and Ziegler (2003) were used to compute densities of fecal coliform bacteria at the two surface water sites. Duration curves for the Little Arkansas River near Halstead, Kans., show that computed fecal coliform concentrations exceeded the primary contact recreational criterion about 70 percent of the time and exceeded the secondary contact recreational criterion about 15 percent of the time (fig. 22). At the Little Arkansas River near Sedgwick, Kans., computed fecal coliform concentrations exceeded the primary contact recreational criterion about 52 percent of the time and exceeded the secondary contact recreational criterion about 12 percent of the time (fig. 22).

The fecal coliform criterion does not apply to groundwater. Fecal coliform bacteria were rarely detected in water from IWs (table 4). Fecal coliform detections in IWs may be related to drilling activities because the only detections generally occurred shortly after wells were completed. Indicator bacteria that reach groundwater are not viable because they require dissolved oxygen, and there is little dissolved oxygen in groundwater.

\section{Escherichia coliBacteria}

E. coli is a specific type of fecal coliform bacteria. There also is no EPA Federal drinking-water criterion for $E$. coli bacteria; however, in 2004 the State of Kansas established surface water recreational-use criteria. The criteria for

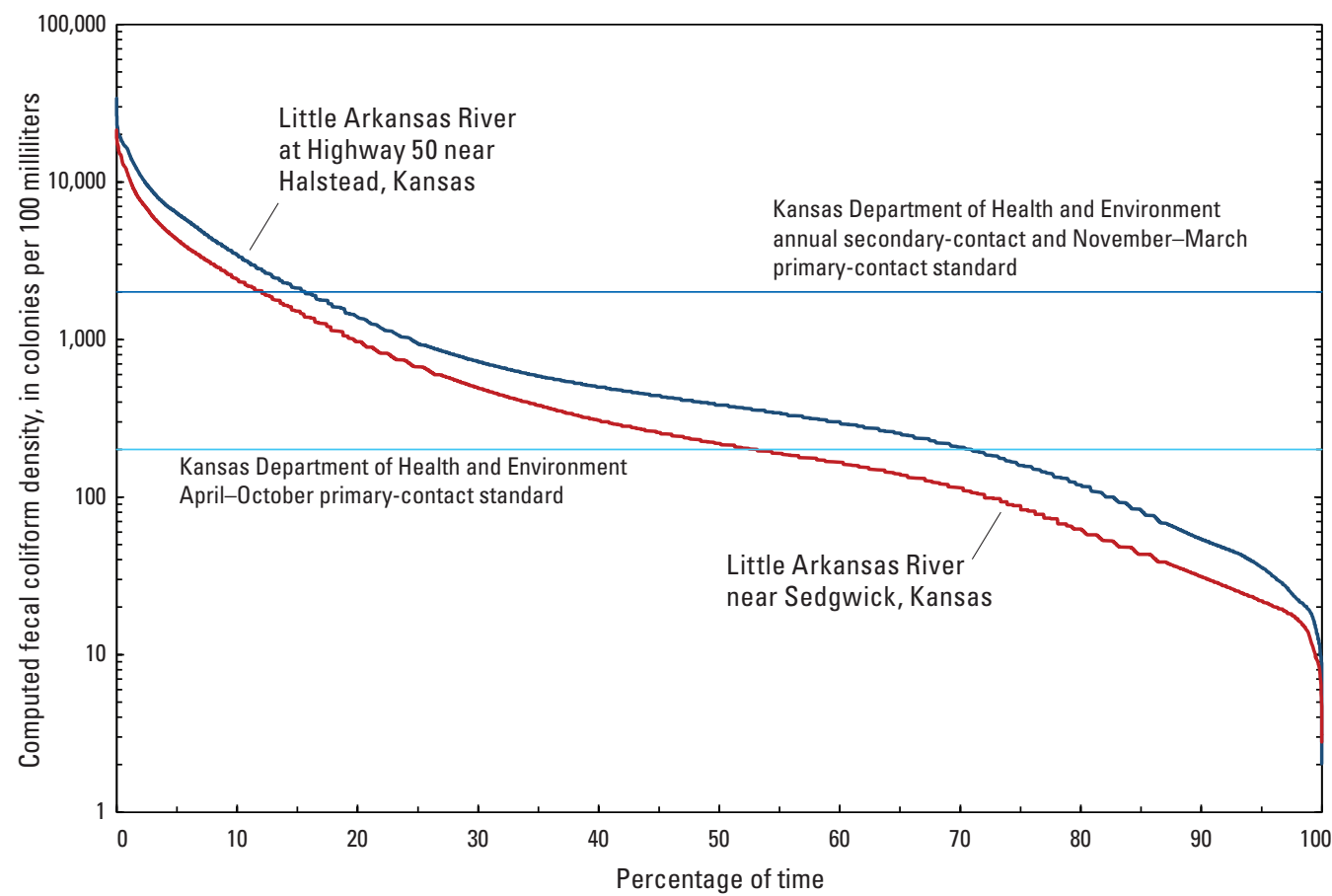

Figure 22. Duration curves of computed fecal coliform bacteria densities, 1999-2012, Little Arkansas River near Halstead and near Sedgwick, Kansas. 


\section{Water Quality of the Little Arkansas River and Equus Beds Aquifer Before and Concurrent with Large-Scale Artificial Recharge}

publicly accessible (Class B) Kansas streams with flows of at least 1 cubic foot per second $\left(\mathrm{ft}^{3} / \mathrm{s}\right)$ require that the geometric mean of at least five samples collected during separate 24-hour periods within a 30-day period not exceed 262 colony forming units per 100 milliliters $(\mathrm{CFU} / 100 \mathrm{~mL})$ for primary contact during April 1 through October 31 of each year and $2,358 \mathrm{CFU} / 100 \mathrm{~mL}$ for primary contact during the rest of the year. For secondary contact, the geometric mean should not exceed 2,358 CFU/100 mL at any time of year (Kansas Department of Health and Environment, 2004). For the purposes of this report, $\mathrm{CFU} / 100 \mathrm{~mL}$ are considered equivalent to colonies per $100 \mathrm{~mL}$.

Median E. coli bacteria densities in water samples collected during 1995 through 2012 at the Little Arkansas River near Halstead, Kans., were 1,020 col/100 mL for April through October and $108 \mathrm{col} / 100 \mathrm{~mL}$ for November through March (table 3). Median E. coli bacteria densities in water samples collected during 1995 through 2012 at the Little Arkansas River near Sedgwick, Kans., were 1,070 col/100 mL for April through October and $206 \mathrm{col} / 100 \mathrm{~mL}$ for November through March (table 3). Of the samples collected from the Little Arkansas River during 1995 through 2012, about 76 percent of those collected during April-October exceeded the publicaccess primary contact standard for E. coli of $262 \mathrm{col} / 100$ $\mathrm{mL}$. About 16 percent of the samples collected from the Little Arkansas River during November through March exceeded the public-access primary and secondary standard for $E$. coli of 2,358 col/100 $\mathrm{mL}$ (table 3).
Densities of E. coli bacteria were computed using continuous measurements of turbidity in streams (Rasmussen and Ziegler, 2003). The Little Arkansas River near Halstead's computed $E$. coli concentrations exceeded the public-access primary contact recreational criterion about 55 percent of the time and exceeded the public-access secondary contact recreational criterion about 10 percent of the time during 1999 through 2012 (fig. 23). At the Little Arkansas River near Sedgwick, Kans., during 1999 through 2012, computed E. coli densities exceeded the public-access primary contact recreational criterion about 41 percent of the time and exceeded the public-access secondary contact recreational criterion about 10 percent of the time (fig. 23). Computed E. coli data and regression models are available online at http://nrtwq.usgs. gov $/ \mathrm{ks} /$. The recreational-use criteria for $E$. coli do not apply to groundwater, and only a few groundwater samples analyzed for $E$. coli had detections that exceeded $1 \mathrm{col} / 100 \mathrm{~mL}$ (table 4).

\section{Viral Indicators}

Viral indicators Clostridium perfringens and E. coli coliphage were analyzed in water samples from the Little Arkansas River and selected groundwater samples. Clostridium perfringens was detected at concentrations as much as $356 \mathrm{col} / 100 \mathrm{~mL}$, and E. coli coliphage was detected at concentrations varying from 40 to 1,300 plaque forming units per $100 \mathrm{~mL}$ (pfu/100 mL) in storm-water samples from the Little Arkansas River. These viral indicators were not detected in

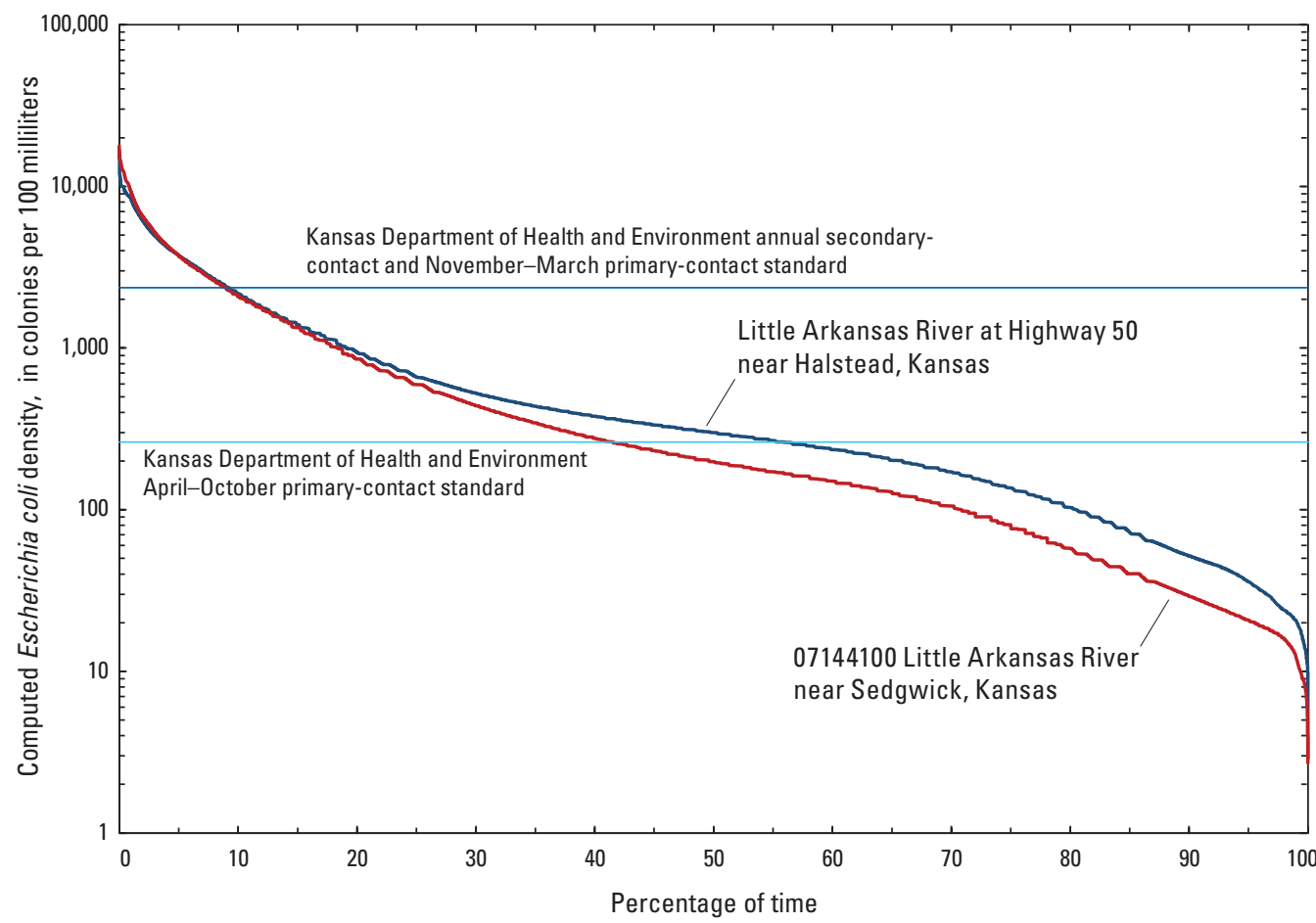

Figure 23. Duration curves of computed Escherichia coli bacteria densities, 1999-2012, Little Arkansas River near Halstead and near Sedgwick, Kansas. 
any samples of groundwater. These data indicate that natural infiltration of water through the soil removes viral indicator organisms. (Ziegler and others, 2010).

\section{Timeline of Water Quality at and Near Phase I Recharge Sites}

The water quality at and near Phase I recharge sites can be examined over the period before large-scale artificial recharge began to 2012 (figs. 24-29; table 4). Total coliform bacteria was the only constituent of concern that had a greater percentage of samples exceeding Federal criteria in ASR Phase I source water than in ASR Phase I shallow and deep monitoring wells (table 4). Nearly every total coliform bacteria detection was from the two recharge basin locations (RB-1 and RB-2), where diverted surface water was used for recharge. The average concentration of sulfate, chloride, arsenic, iron, and manganese in ASR Phase I source water samples was substantially lower than in ASR Phase I monitoring well samples (table 4), indicating that the mixing of artificial recharge water and background aquifer water will likely decrease the concentrations of these major ions and trace elements in groundwater.

A timeline of concentrations of chloride, atrazine, and arsenic during 2002-2012 at ASR Phase I recharge monitoring sites is presented in figures 24-29. The recharge sites associated with Phase I artificial recharge include RRW-1, RRW-2, RWW-3, RRW-4, RB-1, and RB-2 (fig. 1). At RRW-1, the farthest north recharge site, chloride, atrazine, and arsenic concentrations are all less than their respective EPA drinkingwater criteria (fig. 24); artificial recharge had no quantifiable effect on chloride, atrazine, or arsenic concentrations. At RRW-2 and RRW-3 (figs. 25 and 26), all concentrations of chloride, atrazine, and arsenic were below criteria. RRW-4 is the recharge well that is closest to the Burrton chloride plume (fig. 27). Chloride concentrations are less than the SMCL but are greater than the concentrations near the Phase I recharge wells to the north, and are increasing with time as the Burrton chloride plume moves southeast and east (fig. 14; fig. 27). Arsenic concentrations are also greater than at Phase I recharge wells to the north, as the MCL is exceeded in some of the wells, but does not appear to be increasing with time. Atrazine concentrations at RRW-4 remain well below the MCL levels. Increasing concentrations of chloride also is occurring at RB-1 (fig. 28) and RB-2 (fig. 29), but concentrations are still below the chloride SMCL. Arsenic concentrations exceed the MCL for the deep wells at RB-1, while several shallow wells exceed the MCL at RB-2. The arsenic concentrations do not appear to be increasing with time near any of the Phase I recharge wells. 

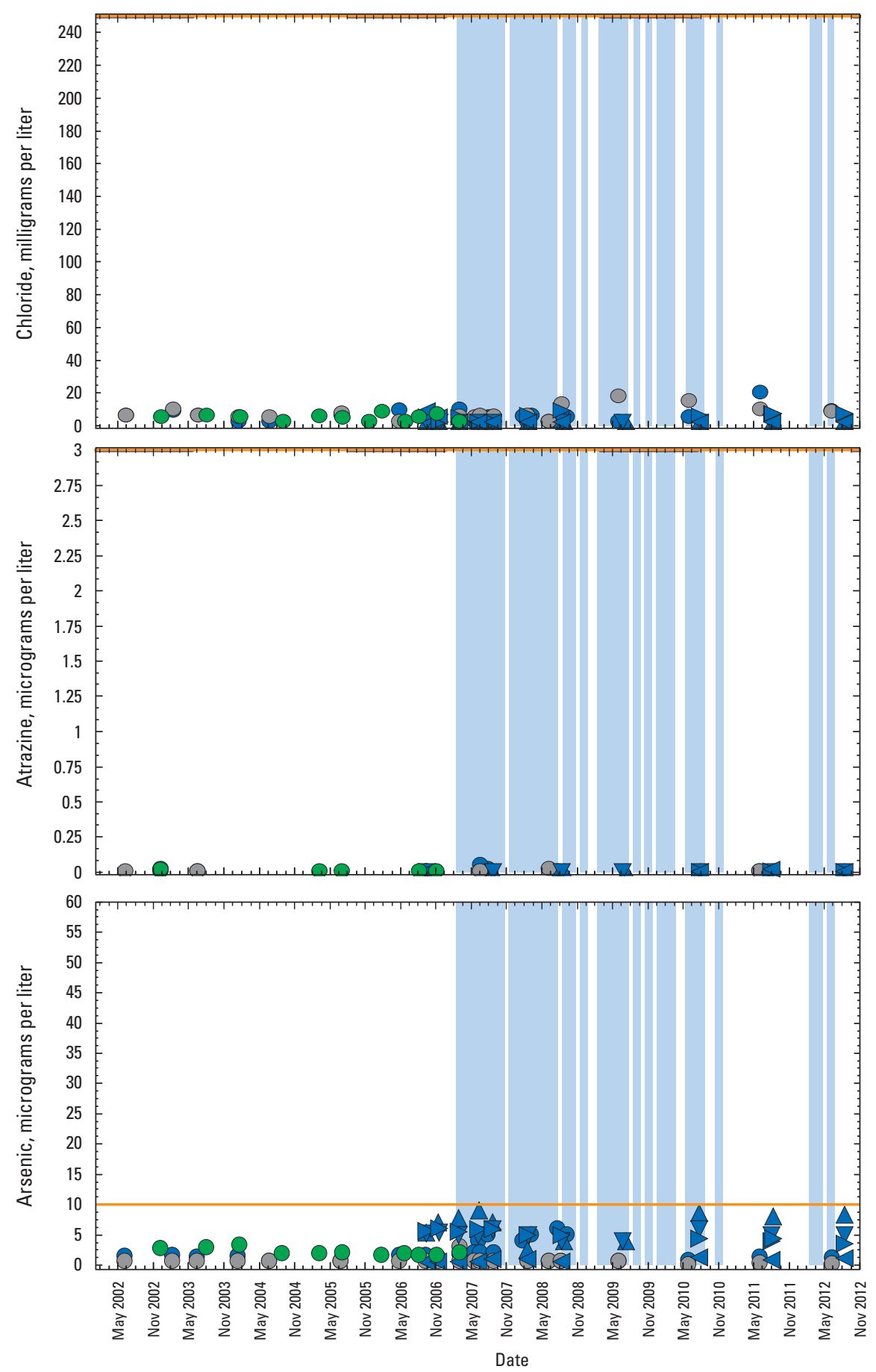

EXPLANATION

$\begin{array}{lll}\text { Artificial recharge period } & \text { Monitoring wells to north } & \text { Monitoring wells to east } \\ \text { Federal drinking-water criteria } & \triangle \text { Shallow } & \text { Shallow } \\ \text { Recharge site } & \triangle \text { Deep } & \text { Moep } \\ \text { Monitoring at recharge site } & \text { Monitoring wells to south } & \text { Shallow } \\ \bigcirc \quad \text { Shallow } & \nabla \text { Shallow } & \text { Deep } \\ \quad \text { Deep } & \nabla \text { Deep }\end{array}$

Figure 24. Chloride, atrazine, and arsenic concentration plots and recharge activity associated with RRW-1 during 2002 to 2012, south-central Kansas. 

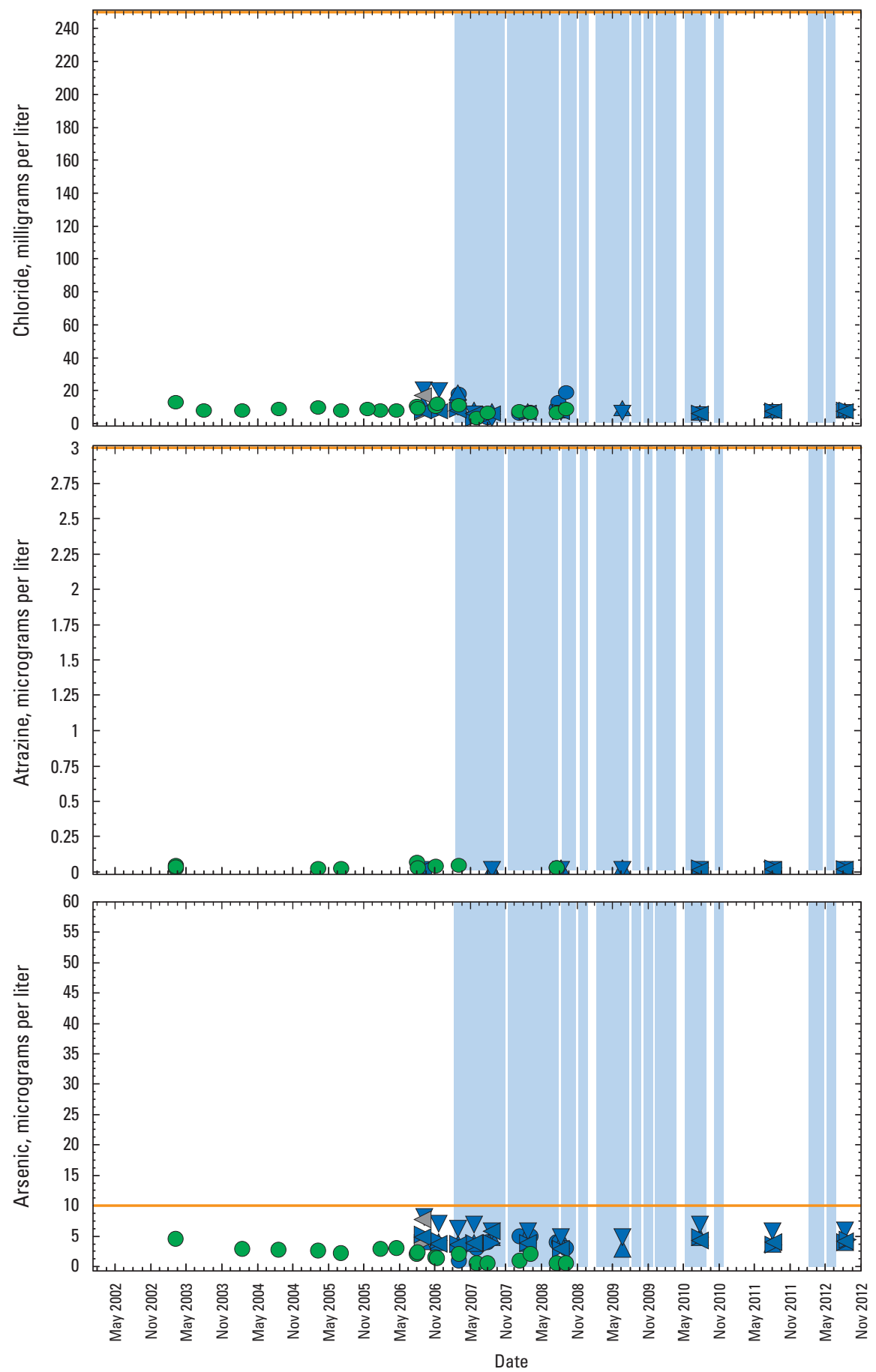

EXPLANATION

$\begin{array}{lll}\text { Artificial recharge period } & \text { Monitoring wells to north } & \text { Monitoring wells to east } \\ \text { Federal drinking-water criteria } & \triangle \text { Shallow } & \text { Shallow } \\ \text { Recharge site } & \triangle \text { Deep } & \text { Monitoring wells to west } \\ \text { Monitoring at recharge site } & \text { Monitoring wells to south } & \text { Shallow } \\ \bigcirc \quad \text { Shallow } & \nabla \text { Shallow } & \text { Deep } \\ \quad \text { Deep } & \nabla \text { Deep }\end{array}$

Figure 25. Chloride, atrazine, and arsenic concentration plots during 2002 to 2012 and recharge activity associated with RRW-2, south-central Kansas. 

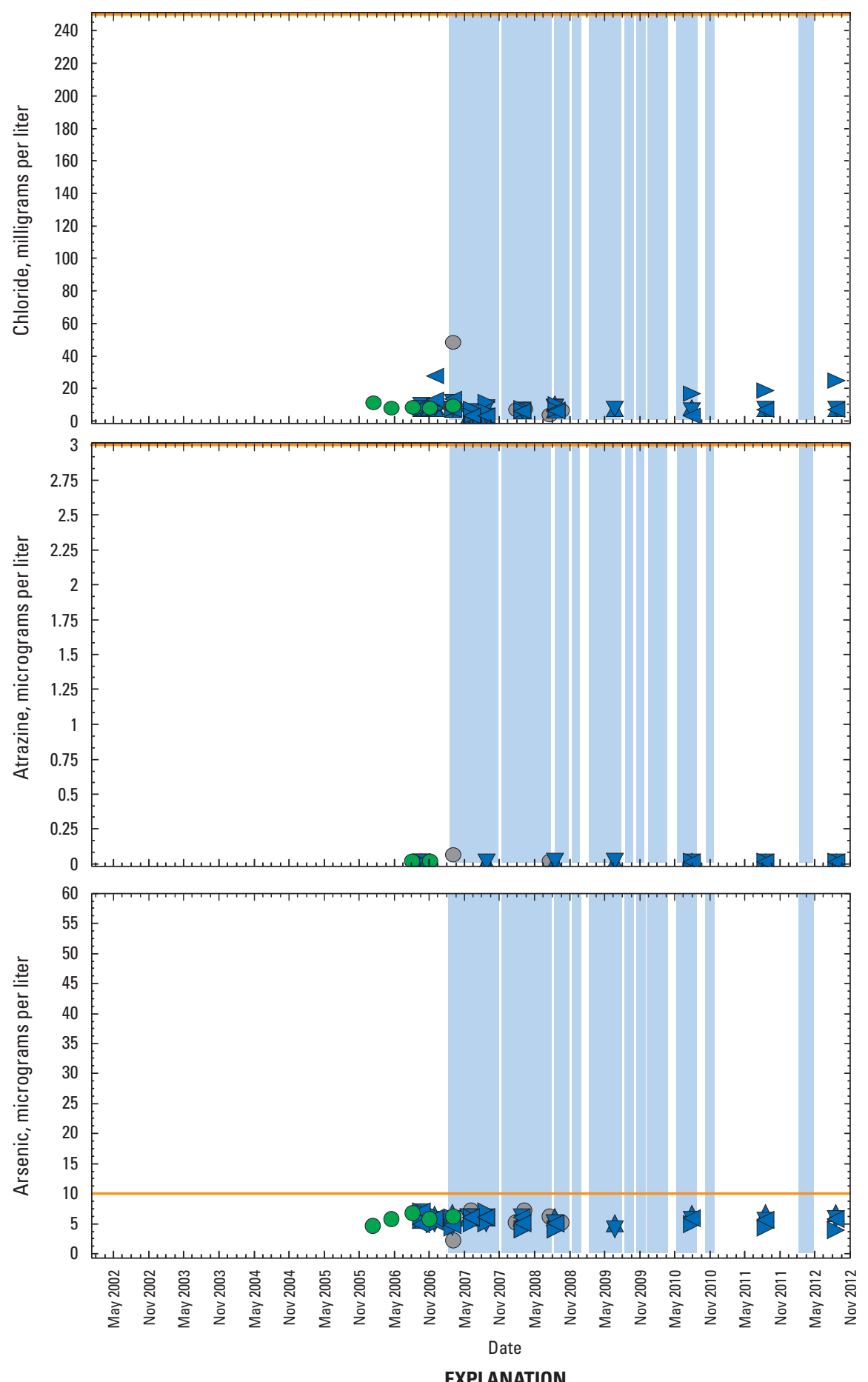

$\begin{array}{lll}\text { Artificial recharge period } & \text { Monitoring wells to north } & \text { Monitoring wells to east } \\ \text { Federal drinking-water criteria } & \triangle \text { Shallow } & \text { Shallow } \\ \text { Recharge site } & \triangle \text { Deep } & \text { Meep } \\ \text { Monitoring at recharge site } & \text { Monitoring wells to south } & \checkmark \text { Shallow } \\ \bigcirc \quad \text { Shallow } & \nabla \text { Shallow } & \text { Deep } \\ \quad \text { Deep } & \nabla \text { Deep }\end{array}$

Figure 26. Chloride, atrazine, and arsenic concentration plots during 2002 to 2012 and recharge activity associated with RRW-3, south-central Kansas. 

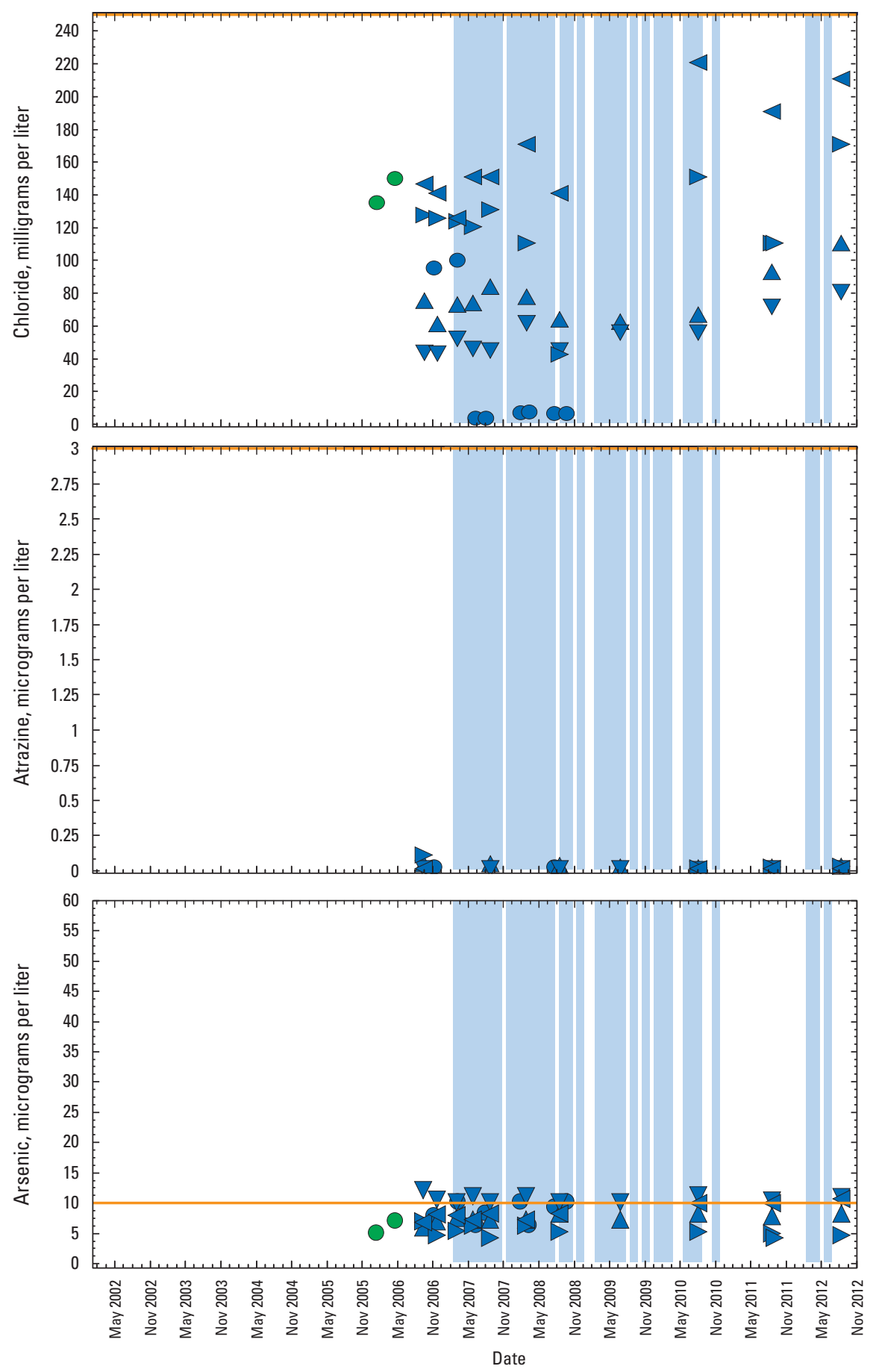

EXPLANATION

$\begin{array}{lll}\text { Artificial recharge period } & \text { Monitoring wells to north } & \text { Monitoring wells to east } \\ \text { Federal drinking-water criteria } & \triangle \text { Shallow } & \text { Shallow } \\ \text { Recharge site } & \triangle \text { Deep } & \text { Moep } \\ \text { Monitoring at recharge site } & \text { Monitoring wells to south } & \checkmark \text { Shallow } \\ \bigcirc \quad \text { Shallow } & \nabla \text { Shallow } & <\text { Deep } \\ \quad \text { Deep } & \nabla \text { Deep }\end{array}$

Figure 27. Chloride, atrazine, and arsenic concentration plots during 2002 to 2012 and recharge activity associated with RRW-4, south-central Kansas. 

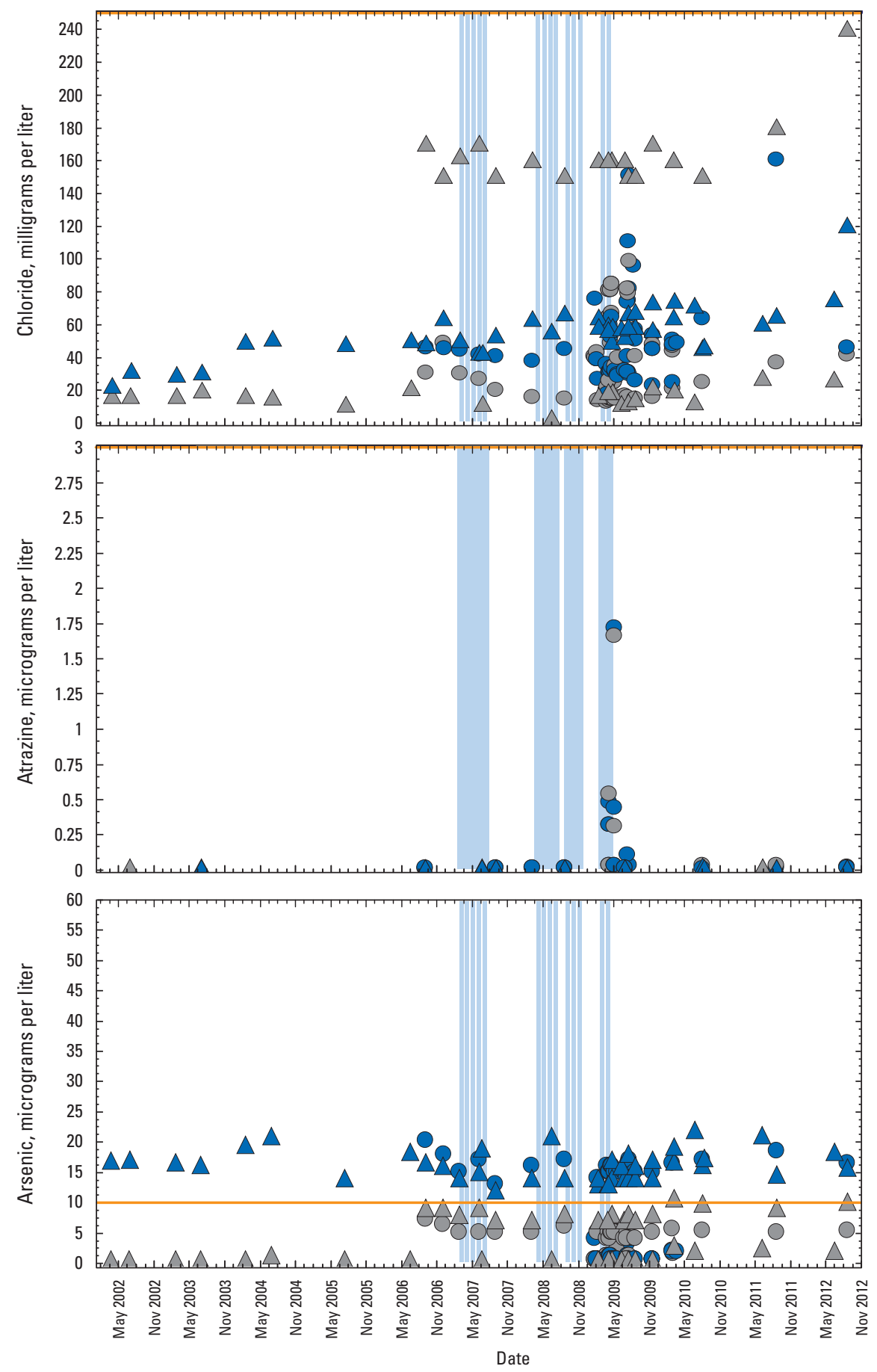

EXPLANATION

\begin{tabular}{lll} 
Artificial recharge period & Monitoring wells to north & Monitoring wells to east \\
\hline Federal drinking-water criteria & $\triangle$ Shallow & Shallow \\
Recharge site & $\triangle$ Deep & Monitoring wells to west \\
Monitoring at recharge site & Monitoring wells to south & Shallow \\
$\quad$ Shallow & $\nabla$ Shallow & \\
$\quad$ Deep & $\nabla$ Deep
\end{tabular}

Figure 28. Chloride, atrazine, and arsenic concentration plots during 2002 to 2012 and recharge activity associated with RB-1, south-central Kansas. 

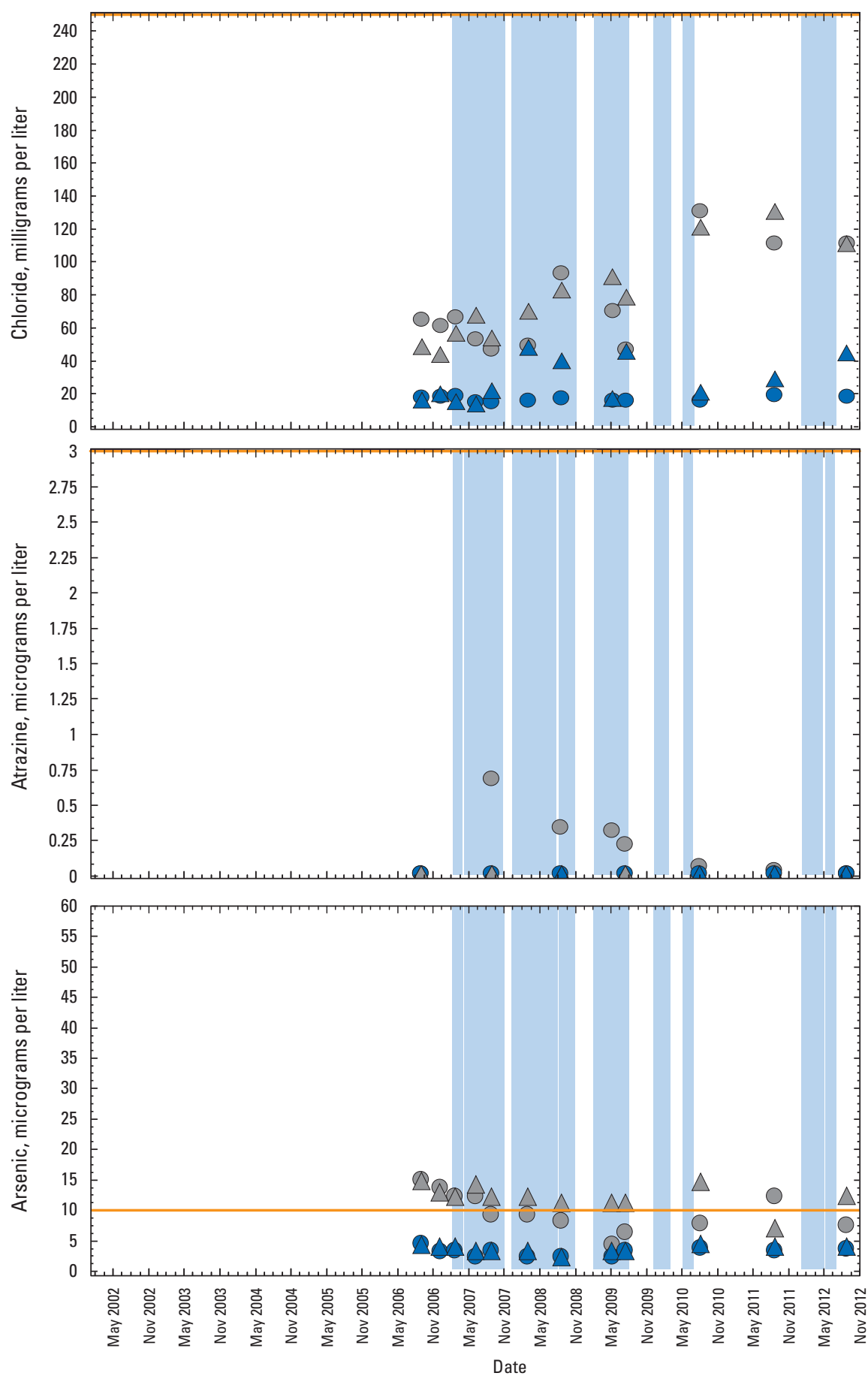

EXPLANATION

Artificial recharge period
Federal drinking-water criteria
Recharge site
Monitoring at recharge site
$\bigcirc \quad$ Shallow
$\bigcirc \quad$ Deep

Monitoring wells to north

$\triangle$ Shallow

Monitoring wells to east

$\triangle$ Deep

$>$ Shallow

Monitoring wells to south $\checkmark$ Shallow

Monitoring wells to west

$\triangleleft$ Shallow

$\nabla$ Deep

$<$ Deep

Figure 29. Chloride, atrazine, and arsenic concentration plots during 2002 to 2012 and recharge activity associated with $\mathrm{RB}-2$, south-central Kansas. 


\section{Summary and Conclusions}

This report, prepared in cooperation by the U.S. Geological Survey and the city of Wichita, Kansas, summarizes Little Arkansas River (source-water for artificial recharge) and Equus Beds aquifer water quality before (1995-2006) and during (2007-2012) ASR Phase I recharge. Water quality in the Equus Beds aquifer was defined using samples collected at 38 areal assessment index well sites (IWs), 7 diversion well sites, 13 background wells, 9 Artificial Storage and Recovery prototype wells, and 66 Artificial Storage and Recovery Phase I and Phase II monitoring wells. Samples were analyzed for major ions, nutrients, trace metals, radionuclides, organic compounds, and bacterial and viral indicators. Federal and State drinking-water criteria were used to evaluate aquifer water quality.

Constituents of concern for artificial recharge are major ions (sulfate, chloride), nutrients (nitrate), trace elements (arsenic, iron, and manganese), triazine herbicides (atrazine), and fecal indicator bacteria. Water chemistry in surface water and groundwater is controlled by the geology of the underlying bedrock and aquifer materials, the hydrologic (effective porosity) and geochemical (oxidation-reduction potential $[\mathrm{ORP}]$ ) properties of the aquifer, and the effects of humans related to past oil and gas activities, and agriculture.

Sulfate concentrations in water samples from the Little Arkansas River rarely exceeded the Federal secondary maximum contaminant level (SMCL) of 250 milligrams per liter (mg/L). Sulfate concentrations during 2001-2012 exceeded the SMCL in groundwater in 18.7 percent of the shallow IWs and in 12.9 percent of the deep IWs. Larger sulfate concentrations were associated with parts of the aquifer with the largest water-level declines. Water-quality changes in the Equus Beds aquifer likely were caused by dewatering and oxidation of aquifer material that subsequently resulted in increased sulfate concentrations as water levels recovered.

Primary sources of chloride to the Equus Beds aquifer are from past oil and gas activities near Burrton, Kans., naturally occurring saline water from the Arkansas River, municipal wastewater, industrial discharges, and mineralized water from the underlying Wellington Formation. Computed chloride concentrations during 1999-2012 in the Little Arkansas River near Halstead, Kans., exceeded the Federal SMCL of 250 $\mathrm{mg} / \mathrm{L}$ about 20 percent of the time (primarily during low-flow conditions). Chloride concentrations during 2001-2012 in groundwater exceeded the SMCL in 5.6 percent of the samples from the shallow IWs and 7.4 percent from the deep IWs, primarily near Burrton, Kans., and along the Arkansas River. The downward and horizontal migration of chloride is controlled by the hydraulic gradient in the aquifer, dispersion of chloride, and discontinuous clay layers that can inhibit further downward migration. The eastward movement of the Burrton chloride plume is likely being slowed by a line of recharge locations associated with ASR Phase I; however, the line depicting average chloride concentrations in deep groundwater during 2006-2012 still advanced to less than one half mile from the central part of the study area.

Nutrients, such as nitrate, are a water-quality concern because of the predominant agricultural land use in the 189-square-mile study area. Almost all (more than 99.6 percent) nitrate concentrations in water samples collected at the two surface water monitoring sites on the Little Arkansas River from 1995 through 2012 were less than the Federal maximum contaminant level (MCL) of $10 \mathrm{mg} / \mathrm{L}$ for nitrate. Nitrate concentrations in groundwater samples during 2001-2012 exceeded the MCL in 15.7 percent of the shallow IWs. Nitrate concentrations were minimal in the deeper parts of the aquifer because of chemically reducing conditions. Increased nitrate concentrations in shallow and deep groundwater likely were partly controlled by larger effective porosity in these same areas, which allows for more rapid percolation from agricultural land uses.

Several trace elements frequently exceeded drinkingwater criteria, including arsenic, iron, and manganese. Computed arsenic concentrations in the Little Arkansas River at Highway 50 near Halstead, Kans., during 1999-2012 exceeded the Federal MCL of 10 micrograms per liter $(\mu \mathrm{g} / \mathrm{L})$ about 19 percent of the time, primarily during low-flow conditions. In shallow groundwater, arsenic concentrations during 2001-2012 exceeded the MCL in 11.9 percent of the IW samples, whereas for the deep IW samples, arsenic concentrations exceeded the MCL in 34.6 percent of the samples. Average arsenic concentrations exceeding the MCL in the shallow parts of the aquifer generally were located near Halstead, Kans., and the central part of the study area. The central part of the study area corresponds to the areas that had the most water-level recovery since 1993. Larger arsenic concentrations in deep wells were most common in areas with reducing conditions where ORP was less than 250 millivolts.

Other dissolved trace elements of concern in the study area were iron and manganese, which exceeded the U.S. Environmental Protection Agency Federal SMCL in surface and groundwater. In the Little Arkansas River during 1995-2012, dissolved iron concentrations exceeded the SMCL of 300 $\mu \mathrm{g} / \mathrm{L}$ in only about 5 percent of the samples, and manganese concentrations exceeded the SMCL of $50 \mu \mathrm{g} / \mathrm{L}$ in about half the samples. In the shallow IWs during 2011-2012, iron concentrations exceeded the iron SMCL in 37.2 percent of the samples. Manganese concentrations in shallow IWs exceeded manganese SMCL in 54.6 percent of the samples. In deep IWs, iron concentrations exceeded the iron SMCL in 44.6 percent of the samples, and manganese concentrations exceeded the manganese SMCL in 91.8 percent of samples. Areas with largest concentrations of iron and manganese corresponded to areas with largest water-level declines that have subsequently recovered and the areas with the more chemically reducing conditions.

The areal distribution of larger dissolved arsenic, iron, and manganese concentrations were similar. Larger naturallyoccurring concentrations of arsenic, iron, and manganese in groundwater are associated with more reducing conditions, 
areas where more clay is present in the aquifer material, and areas that had large water-level declines and subsequent recovery. Effects of artificial recharge on natural dissolved concentrations of arsenic in the aquifer potentially can be minimized by maintaining the ORP as near 1995-2012 baseline conditions as possible. However, in many areas of the aquifer, especially the deeper parts, the natural geochemical conditions are conducive to large arsenic concentrations. It may be possible to use artificial recharge of oxygenated water to create a less reducing geochemical environment, which could decrease the concentrations of dissolved arsenic and iron in the aquifer but could also increase nitrate concentrations, which may potentially create a general improvement of the overall aquifer water quality.

Atrazine was the most commonly detected organic compound in the study area. The Federal MCL for atrazine in drinking water is an annual average of $3 \mu \mathrm{g} / \mathrm{L}$. Computed concentrations of atrazine in the Little Arkansas River near Sedgwick, Kans., during 1999-2012 exceeded the Federal MCL value of $3.0 \mu \mathrm{g} / \mathrm{L}$ about 28 percent of the time, mostly during the late spring to early fall. Atrazine was detected in 57.0 percent of the samples collected from shallow wells, which indicates infiltration from field applications to the shallow groundwater, but all concentrations were much less than the MCL.

Large concentrations of coliform bacterial indicators (total coliform, fecal coliform, and Escherichia coli) were detected in all water samples from the Little Arkansas River. These large bacterial indicator densities are typical in central and eastern Kansas streams, especially during runoff conditions. Total coliform detections during 2001-2012 exceeded the U.S. Environmental Protection Agency Federal maximum contaminant level goal of 0 colonies in water samples from 24.7 percent of the shallow IWs and in 12.4 percent of the deep IWs. Many of these detections were in the first samples collected from the wells after they were developed, indicating that at least some of these detections may be related to drilling. Almost all wells sampled for this study had at least one sample with a total coliform detection; however, the median densities for most of these wells were less than 1 colony per 100 milliliters. Viral indicators (Clostridium perfringens and Escherichia coli coliphage) were present in samples from the Little Arkansas River during storm runoff but were not detected in any samples of groundwater. These data indicated that natural infiltration of water through the soil removes bacterial and viral indicator organisms.

Surface water and groundwater quality is controlled by underlying bedrock geology and aquifer material, aquifer hydraulic permeability (porosity) and geochemical (ORP, pH) properties, and human-related effects of agricultural and past oil and gas activities. When the proposed full-scale artificial recharge of the Equus Beds aquifer is implemented, changes in concentrations of water-quality constituents are expected. Increased water levels from artificial recharge are expected to slow saltwater migration from the northwest and south of the study area, potentially limiting further chloride migration and improving the quality of water in the aquifer. Continued monitoring and interpretation of these recharge water-quality data relative to drinking-water criteria will provide critical information that can be used by water managers to verify the preservation of the quality of water in the Equus Beds aquifer.

Constituents and physical properties of interest for each of the shallow and deep IWs include arsenic, chloride, iron, manganese, nitrite plus nitrate, ORP, specific conductance, and sulfate. As a group, all constituents of interest except chloride, arsenic, and ORP had average values increase from the 2001 to 2006 period to the 2007 to 2012 period in the IW network. Iron concentration increases are likely linked to decreases in ORP. Average concentration increases of constituents of interest and ORP decreases from 2006 to 2012 is likely linked to drought conditions during 2010-2012. Lower precipitation amounts limit diluting effects of new-water recharge.

Recharge activities at Phase I recharge wells have not resulted in substantial effects on groundwater quality in the area because the amount of water recharged is relatively small ( 1 billion gallons) compared to the aquifer storage volume (greater than 990 billion gallons in winter 2012). Water-quality constituents of concern outlined here have not increased substantially and are likely more affected by climatological (natural recharge by precipitation) and natural processes (geochemical oxidation/reduction, metabolic and decay rates) than artificial recharge. Arsenic remains a water-quality constituent of concern because of natural and continued persistence of concentrations exceeding the Federal MCL of $10 \mu \mathrm{g} / \mathrm{L}$, especially in deeper parts of the Equus Beds aquifer.

\section{References Cited}

Armon, R., and Payment, P., 1988, A modified m-CP medium for enumerating Clostridium perfringens from water samples: Canadian Journal of Microbiology, v. 34, p. 78-79.

Aucott, W.R., Myers, N.C., and Dague, B.J., 1998, Status of groundwater levels and storage in the Wichita well field area, south-central Kansas, 1997: U.S. Geological Survey Water-Resources Investigations Report 98-4095, 15 p.

Bauder, T.A., Waskom, R.M., and Davis, J.G., 2007, Irrigation water quality criteria: Colorado State University Extension, accessed July 14, 2008, at http://www.ext.colostate.edu/ PUBS/crops/00506.html.

Bisson, J.W., and Cabelli, V.J., 1979, Membrane filter enumeration method for Clostridium perfringens: Applied and Environmental Microbiology, v. 37, no. 1, p. 55-66.

Bisson, J.W., and Cabelli, V.J., 1980, Clostridium perfringens as a water pollution indicator: Journal of the Water Pollution Control Federation, v. 52, no. 2, p. 241-248. 
Britton, L.J., and Greeson, P.E., 1987, Methods for collection and analysis of aquatic biological and microbiological samples: U.S. Geological Survey Techniques of WaterResources Investigations, book 5, chap. A4, [variously paged], accessed March 13, 2008, at http://pubs.usgs.gov/ twri/twri5a $4 / \mathrm{html} / \mathrm{pdf} . \mathrm{html}$.

Christensen, V.G., Jian, Xiaodong, and Ziegler, A.C., 2000, Regression analysis and real-time water-quality monitoring to estimate constituent concentrations, loads, and yields in the Little Arkansas River, south-central Kansas, 1995-99: U.S. Geological Survey Water-Resources Investigations Report 00-4126, 36 p.

Christensen, V.G., Ziegler, A.C., Rasmussen, P.P., and Jian, Xiaodong, 2003, Continuous real-time water-quality monitoring of Kansas streams, in Proceedings of 2003 Spring Specialty Conference on Agricultural Hydrology and Water Quality, May 12-14, 2003, Kansas City, Missouri: Middleburg, Va., American Water Resources Association Technical Publication Series No. TPS-03-1, CD-ROM.

Dufour, A.P., 1984, Bacterial indicators of recreational water quality: Canadian Journal of Public Health, v. 75, no. 1, p. 49-56.

Dufour, A.P., Strickland, E.R., and Cabelli, V.J., 1981, Membrane filter method for enumerating Escherichia coli: Applied and Environmental Microbiology, v. 41, no. 5, p. 1152-1158.

Equus Beds Groundwater Management District No. 2, 1990, Equus Beds Groundwater Management District No. 2 management program: Halstead, Kans., 91 p.

Garbarino, J.R., Bedner, A.J., and Burkhardt, M.R., 2002, Methods of analysis by the U.S. Geological Survey National Water Quality Laboratory and field methods-Arsenic speciation in natural-water samples using laboratory and field methods: U.S. Geological Survey Water-Resources Investigations Report 2002-4144, $40 \mathrm{p}$.

Garinger, L.P., King, A.S., and Ziegler, A.C., 2011, Effects of experimental passive artificial recharge of treated surface water on water quality in the Equus Beds Aquifer, 20092010: U.S. Geological Survey Scientific Investigations Report 2011-5070, $106 \mathrm{p}$.

Hansen, C.V., 2007, Status of groundwater levels and storage volume in the Wichita well field area, south-central Kansas, January 2003-January 2006: U.S. Geological Survey Scientific Investigations Report 2006-5321, 34 p.

Hansen, C.V., Whisnant, J.A., and Lanning-Rush, J.L., 2014, Status of groundwater levels and storage volume in the Equus Beds aquifer near Wichita, Kansas, 2012 to 2014: U.S. Geological Survey Scientific Investigations Report 2014-5185, $39 \mathrm{p}$.
Hansen, C.V., and Aucott, W.R., 2001, Status of groundwater levels and storage volume in the Wichita well field area, south-central Kansas, 1998-2000: U.S. Geological Survey Water-Resources Investigations Report 00-4267, 27 p.

Hansen, C.V., and Aucott, W.R., 2004, Status of groundwater levels and storage volume in the Equus Beds aquifer near Wichita, Kansas, January 2000-January 2003: U.S. Geological Survey Water-Resources Investigations Report 03-4298, $36 \mathrm{p}$.

Hathaway, L.R., Waugh, T.C., Galle, O.K., and Dickey, H.P., 1981, Chemical quality of irrigation waters in the Equus Beds area, south-central Kansas: Kansas Geological Survey Chemical Quality Series 10, 45 p.

Helsel, D.R., 2005, Nondetects and data analysis-Statistics for censored environmental data: Hoboken, N.J., John Wiley and Sons, $250 \mathrm{p}$.

Helsel, D.R., and Hirsch, R.M., 1992, Statistical methods in water resources: New York, Elsevier, 522 p.

Helsel, D.R., and Hirsch, R.M., 2002, Statistical methods in water resources: U.S. Geological Survey Techniques of Water-Resources Investigation, book 4, chap. A3, 523 p., accessed July 1, 2008, at http://pubs.usgs.gov/twri/ twri4a3/\#pdf.

Hem, J.D., 1992, Study and interpretation of chemical characteristics of natural water (3d ed.): U.S. Geological Survey Water-Supply Paper 2254, 263 p.

Hinkle, S.R., and Polette, D.J., 1999, Arsenic in groundwater of the Willamette Basin, Oregon: U.S. Geological Survey Water-Resources Investigations Report 98-4204, 28 p.

Kansas Department of Agriculture, 2006, Kansas farm facts 2006: Topeka, Kans., 103 p.

Kansas Department of Health and Environment, 2001, Kansas administrative regulation, article 28-16-28e, surface water quality standards: Topeka, Kans., Secretary of State, 16 p.

Kansas Department of Health and Environment, 2004, Kansas administrative regulation, article 28-16-28e, surface water-quality standards: Topeka, Kans., Department of Health and Environment, Bureau of Water, accessed November 27, 2007, at http://www.kdheks.gov/water/index. html\#Adopted\%20Regulations.

Kansas Department of Health and Environment, 2006a, Lower Arkansas Basin total maximum daily load-Hutchison to Maize water-quality impairment-Chloride: Topeka, Kans., Department of Health and Environment, Bureau of Water, accessed June 17, 2009, at http://www.kdheks.gov/tmdl/ la/2006_Ark_Hutch_to_MaizeCl.pdf. 
Kansas Department of Health and Environment, 2006b, Lower Arkansas River Basin total maximum daily load-Upper Little Arkansas River, water-quality impairment - Chloride: Topeka, Kans., Department of Health and Environment, Bureau of Water, accessed June 17, 2009, at http://www. kdheks.gov/tmdl/la/UpperLittleArk-ClTMDLFinal.pdf.

Kelly, B.P., Pickett, L.L., Hansen, C.V., and Ziegler, A.C., 2013, Simulation of groundwater flow, effects of artificial recharge, and storage volume changes in the Equus Beds aquifer near the city of Wichita, Kansas well field, 19352008: U.S. Geological Survey Scientific Investigations Report 2013-5042, 90 p.

Klager, B.J., Kelly, B.P., and Ziegler, A.C., 2014, Preliminary simulation of chloride transport in the Equus Beds aquifer and simulated effects of well pumping and artificial recharge on groundwater flow and chloride transport near the city of Wichita, Kansas, 1990 through 2008: U.S. Geological Survey Open-File Report 2014-1162, 76 p.

Leonard, R.B., and Kleinschmidt, M.K., 1976, Saline water in the Little Arkansas River Basin area, south-central Kansas: Kansas Geological Survey Chemical Quality Series No. 3, $24 \mathrm{p}$.

Lohman, S.W., 1972, Definitions of selected groundwater terms-Revisions and conceptual refinements: U.S. Geological Survey Water-Supply Paper 1988, 21 p.

McMahon, P.B., and Chapelle, F.H., 2008, Redox processes and water quality of selected principal aquifer systems: Groundwater, v. 46, no. 2, p. 259-271.

Myers, N.C., Haragadine, G.D., and Gillespie, J.B., 1996, Hydrologic and chemical interactions of the Arkansas River and the Equus Beds aquifer between Hutchinson and Wichita, south-central Kansas: U.S. Geological Survey Water-Resources Investigations Report 95-4191, 100 p.

Payment, P., and Franco, E., 1993, Clostridium perfringens and somatic coliphages as indicators of the efficiency of drinking water treatment for viruses and protozoan cysts: Applied and Environmental Microbiology, v. 59, no. 8, p. 2418-2424.

Rasmussen, P.P., and Ziegler, A.C., 2003, Comparison and continuous estimates of fecal coliform and Escherichia coli bacteria in selected Kansas streams, May 1999 through April 2002: U.S. Geological Survey Water-Resources Investigations Report 03-4056, 80 p.

Sauer, V.B., and Turnipseed, D.P., 2010, Stage measurement at gaging stations: U.S. Geological Survey Techniques and Methods, book 3, chap. A7, 45 p.
Schmidt, H.C.R., Ziegler, A.C., and Parkhurst, D.L., 2007, Geochemical effects of induced stream-water and artificial recharge on the Equus Beds aquifer, south-central Kansas, 1995-2004: U.S. Geological Survey Scientific Investigations Report 2007-5025, 58 p.

Smedley, P.L., and Kinniburgh, D.G., 2002, A review of the source, behavior and distribution of arsenic in natural waters: Applied Geochemistry, v. 17, p. 517-568.

Turnipseed, D.P., and Sauer, B.B, 2010, Discharge measurements at gaging stations: U.S. Geological Survey Techniques and Methods, book 3, chap. A8, 87 p.

U.S. Environmental Protection Agency, 1986, Quality criterion for water, 1986: U.S. Environmental Protection Agency Report 440-5-86-001, [n.p.].

U.S. Environmental Protection Agency, 1996, EPA Information Collection Rule microbial laboratory manual: Washington D.C., EPA-600-R-95-178, section XI.

U.S. Environmental Protection Agency, 2000, Improved enumeration methods for the recreational water quality indicators-Enterococci and Escherichia coli: Washington D.C., Office of Science and Technology, EPA 821-R-97-04, 40 p., accessed March 13, 2008, at http://water.epa.gov/type/ oceb/beaches/upload/2006_06_19_beaches_rvsdman.pdf.

U.S. Environmental Protection Agency, 2001a, Method 1602-Male-specific $(\mathrm{F}+)$ and somatic coliphage in water by single agar layer (SAL) procedure: Washington D.C., Office of Water, EPA 821-4-01-029, 30 p., accessed March 13, 2008, at http://www.epa.gov/nerlcwww/ documents/1602ap01.pdf.

U.S. Environmental Protection Agency, 2005, Current drinking-water standards: accessed August 17, 2005, at http:// water.epa.gov/drink/contaminants/index.cfm.

U.S. Environmental Protection Agency, 2006a, 2006 edition of the drinking water standards and health advisories: Office of Water, EPA 822-R-06-013, 12 p., accessed December 13, 2007, at http://water.epa.gov/drink/standards/hascience.cfm.

U.S. Environmental Protection Agency, 2006b, Method 1103.1-Escherichia coli (E. coli) in water by membrane filtration using membrane-thermotolerant Escherichia coli agar (mTEC): Washington D.C., EPA 821-R-06-010, 45 p., accessed March 13, 2008, at http://water.epa.gov/scitech/ methods/cwa/bioindicators/index.cfm.

U.S. Environmental Protection Agency, 2006c, Method 1106.1-Enterococci in water by membrane filtration using membrane enterococcus esculin iron agar (mE-EIA): Washington D.C., EPA 821-R-06-008, 42 p., accessed March 13, 2008, at http://water.epa.gov/scitech/methods/cwa/bioindicators/upload/method_1106_1.pdf. 
U.S. Environmental Protection Agency, 2006d, Method 1600 - Enterococci in water by membrane filtration using membrane enterococcus indoxyl- $\beta$-D-glucoside agar $(\mathrm{mEI})$ : Washington D.C., EPA 821-R-06-009, 42 p., accessed March 13, 2008, at http://water.epa.gov/scitech/methods/ cwa/bioindicators/upload/method_1600.pdf.

U.S. Environmental Protection Agency, 2006e, Method 1603-Escherichia coli in water by membrane filtration using modified membrane-thermotolerant Escherichia coli: Washington D.C., EPA 821-R-06-011, 42 p., accessed March 13, 2008, at http://water.epa.gov/scitech/methods/ cwa/bioindicators/upload/method_1603.pdf.

U.S. Environmental Protection Agency, 2009, National primary drinking water regulations: Washington D.C., U.S. Environmental Protection Agency, Office of Water, EPA 816-F-09-004.

U.S. Geological Survey, 2006, Collection of water samples (ver. 2.0): U.S. Geological Survey Techniques of WaterResources Investigations, book 9, chap. A4, accessed February 2014 at http://pubs.water.usgs.gov/twri9A4/.

Wagner, R.J., Boulger, R.W., Jr., Oblinger, C.J., and Smith, B.A., 2006, Guidelines and standard procedures for continuous water-quality monitors-Station operation, record computation, and data reporting: U.S. Geological Survey Techniques and Methods, book 1, chap. D3, $51 \mathrm{p}$.

Warren, D.R., Blain, G.T., Shorney, F.L., and Klein, L.J., 1995, IRP - A case study from Kansas: Journal of the American Water Works Association, p. 57-71.

Welch, A.H., Westjohn, D.B., Helsel, D.R., and Wanty, R.B., 2000, Arsenic in groundwater of the United States - Occurrence and geochemistry: Groundwater, v. 38, no. 4, p. 568-604.
Whittemore, D.O., 2000, Water quality of the Arkansas River in southwest Kansas: Kansas Geological Survey Open-File Report 2000-44.

Whittemore, D.O., 2007, Fate and identification of oil-brine contamination in different hydrogeologic settings: Applied Geochemistry, v. 22, no. 10, p. 2099-2114.

Wilde, F.D., and Radke, D.B., eds., 1998, Field measurements, in National field manual for the collection of water-quality data: U.S. Geological Survey Techniques of WaterResources Investigations, book 9, chap. A6, p. 3-20.

Williams, C.C., and Lohman, S.W., 1949, Geology and groundwater resources of a part of south-central Kansas with a special reference to the Wichita municipal water supply: Kansas Geological Survey Bulletin 79, 455 p.

Ziegler, A.C., and Combs, L.J., 1997, Baseline data-collection and quality control protocols and procedures for the Equus Beds Groundwater Recharge Demonstration Project near Wichita, Kansas, 1995-96: U.S. Geological Survey OpenFile Report 97-235, 57 p.

Ziegler, A.C., Christensen, V.G., and Ross, H.C., 1999, Baseline water-quality and preliminary effects of artificial recharge on groundwater, south-central Kansas, 1995-98: U.S. Geological Survey Water-Resources Investigations Report 99-4250, $74 \mathrm{p}$.

Ziegler, A.C., Ross, H.C., Trombley, T.J., and Christensen, V.C., 2001, Effects of artificial recharge on water quality in the Equus Beds aquifer, south-central Kansas, 1995-2000: U.S. Geological Survey Fact Sheet 096-01, 4 p.

Ziegler, A.C., Hansen, C.V., and Finn, D.A., 2010, Water quality in the Equus Beds aquifer and the Little Arkansas River before implementation of large-scale artificial recharge, south-central Kansas, 1995-2005: U.S. Geological Survey Scientific Investigations Report 2010-5023, 143 p. 


\section{Appendix 1.}

Table 1-1. Data-collection sites for Equus Beds Groundwater Recharge Project, south-central Kansas, 1995-2012. Available online at http://pubs.usgs.gov/sir/2015/5023/downloads/table1.1.xlsx.

Figure 1-1. Graph showing median relative percentage differences for replicate samples collected during 1995-2004 (from Ziegler and others, 2010) and 2005-2012 that exceeded 10 percent. All other constituents had less than 10-percent difference. Available online at http://pubs.usgs.gov/ sir/2015/5023/downloads/figures1.1_1.2.xlsx.

Figure 1-2. Graph showing detection frequency of water-quality constituents in blank samples collected during 1995-2004 (from Ziegler and others, 2010) and 2005-2012. All other constituents were detected in less than 1 percent of blank samples. Available online at http://pubs.usgs.gov/sir/2015/5023/ downloads/figures1.1_1.2.xlsx. 
Publishing support provided by:

Rolla Publishing Service Center

For additional information concerning this publication, contact: Director, USGS Kansas Water Science Center

4821 Quail Crest Place

Lawrence, KS 66049

(785) 842-9909

Or visit the Kansas Water Science Center Web site at: http://ks.water.usgs.gov 



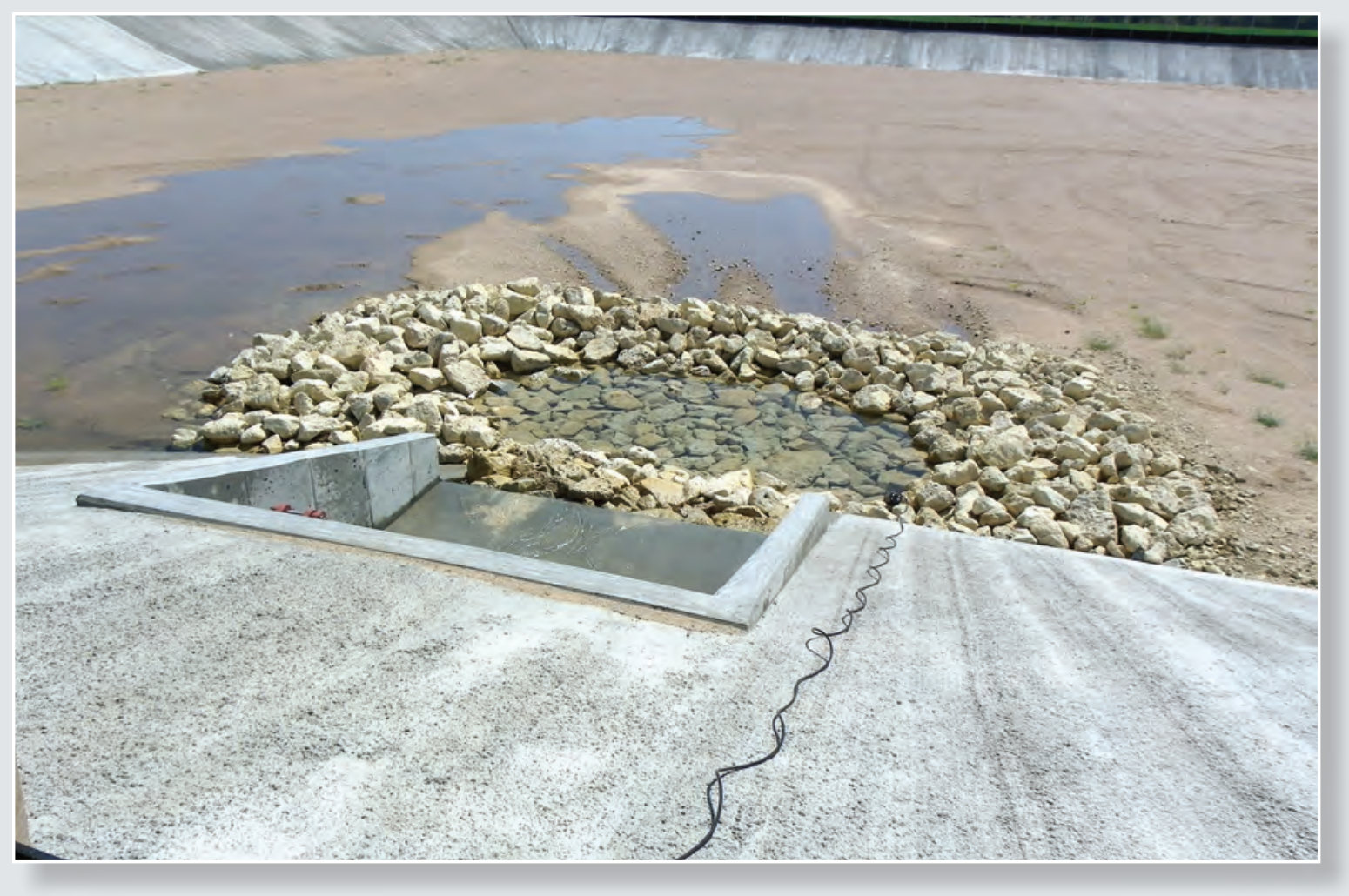

